\title{
USO AGRONÔMICO DE LODO DE ESGOTO: EFEITOS EM FERTILIDADE DO SOLO E QUALIDADE DA CANA- DE-AÇÚCAR
}

\author{
FÁBIO CESAR dA SILVA
}

Engenheiro Agronômo e Florestal

Orientador: Prof. Dr. ANTONIO ENEDI BOARETTO

Tese apresentada à Escola Superior de Agricultura"Luiz de Queiroz", da Universidade de São Paulo, para obtenção do título de Doutor em Agronomia, Área de Concentração: Solơs e Nutrição de Plantas.

PIRACICABA

Estado de São Paulo - Brasil

Agosto - 1995 


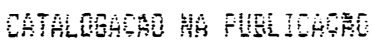

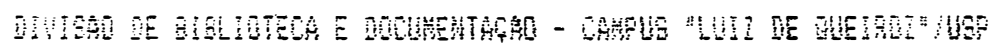

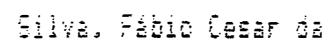

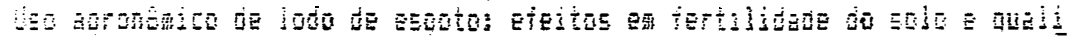

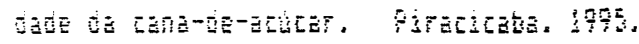

150. Hus.

TEE - EAH

Filiveris.

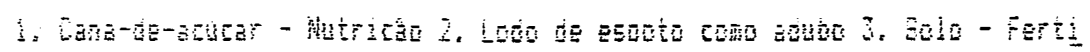

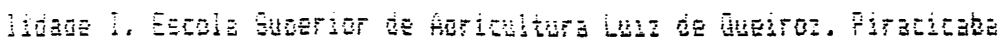

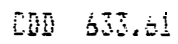
b3. 869 


\section{USO AGRONÔMICO DE LODO DE ESGOTO: EFEITOS EM FERTILIDAE DO SOLO E QUALIDADE DA CANA-DE-AÇÚCAR}

FÁBIO CESAR DA SILVA

Aprovada em : 10.10 .1995 .

Comissão Julgadora:

Prof. Dr. Antonio Enedi Boaretto

CENA/USP

Prof. Dr. Jorge Horii

ESALQ/USP

Prof. Dr. Takashi Muraoka

CENA/USP

Dr. Ronaldo Severiano Berton

IAC

Prof. Dr. Wanderley José de Melo FCA V/UNESP

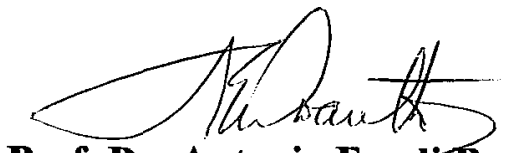

Prof. Dr. Antonio Enedi Boaretto

Orientador 
“A ecologia implica uma mudança ética e filosófica profunda, não se trata de uma moda, mas de um modo de recompor a ordem social sobre novas bases, que levem em conta não só a preocupação conservacionista e os problemas econômicos imediatos, mas sobretudo a finalidade da atividade humana no planeta" ( F. Guattati ).

"As gerações futuras dependem de nós. Se nada for feito hoje, fome e desespero amanhã" (Wajih D. Maalouf).

Aos meus pais : Onofre e Eisa, e aos Tios

Marco Antônio e Maria José que, fizeram-

me compreender o sentido de se ter um

ideal científico, moral e social.

\section{DEDICO}

A minha esposa Trinidade, que nos últimos anos acompanha-me, e vem cultivando o nosso futuro. 


\section{AGRADECIMENTOS}

A todos os que contribuiram para a realização deste trabalho expresso meus agradecimentos, fazendo-o de maneira especial a :

- Professor Dr. Antonio Enedi Boaretto, pela orientação, amizade, apoio e compreensão;

- Dr. Ronaldo Severiano Berton, pela co-orientação, apoio, amizade e estimulo;

- Escola Superior de Agricultura "Luiz de Queiroz"e o Centro de Energia Nuclear na Agricultura - USP e Instituto Agronômico do Estado de São Paulo (IAC), pelo apoio laboratorial, colaboração de vários funcionários, aquisição de novos conhecimentos e a consolidação de minha formação científica e pessoal;

- Empresa Brasileira de Pesquisa Agropecuária (EMBRAPA), em especial ao Centro Nacional de Pesquisa do Solo (CNPS), pela oportunidade para a conclusão da fase experimental e a elaboração da tese;

- Fundação de Amparo à Pesquisa do Estado de São Paulo, pelos recursos financeiros fomecidos ao projeto "Avaliação de características agrotecnológicas e teores de metais pesados da cana-de-açúcar, em face à aplicação do lodo de esgoto ao solo";

- Coordenadoria da Aperfeiçoamento de Pessoal de Nível Superior-CAPES pela bolsa de estudo a nivel de pós-graduação dos dois primeiros anos do curso e ao Conselho Nacional de Desenvolvimento Científico e Tecnológico -CNPq no último ano;

- As bibliotecárias Beatriz Helena Giongo e Kátia M. de Andrade Ferraz, Divisão de Biblioteca do "Campus de Piracicaba", da USP, pela orientação da citação da bibliografia consultada; 
- Ao Professor Dr. Femando Valadares Novais, Departamento de Ciência e Tecnologia Agroindustrial da ESALQ/USP, pela orientação de português do texto e pelo estímulo habitual ;

- A Usina Costa Pinto S/A, em especial aos colegas Helder Basaglia Zotelli, Carlos Alberto Pexe e Elaine Mendonça, pelas facilidades oferecidas na condução do ensaio. 


\section{SUMÁRIO}

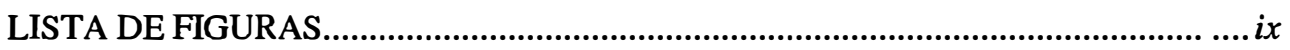

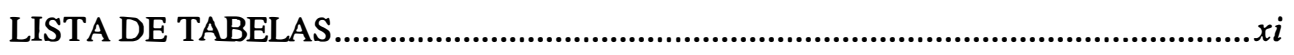

LISTA DE ABREVIATURAS.............................................................................

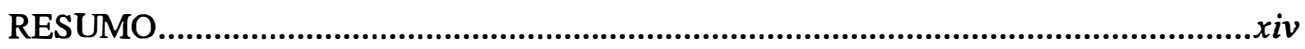

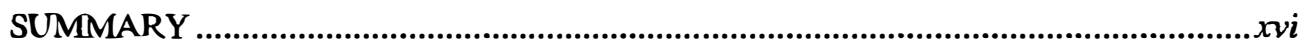

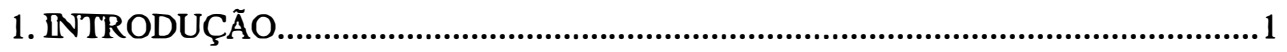

2. REVISÃO DE LITERATURA ….......................................................................

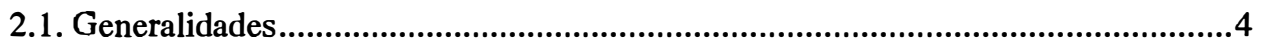

2.2. Sistemas de Tratamento do Esgoto para Obtenção do Le em Barueri-SP ..............6

2.3. Composição Quírnica , Física e Presença de Patógenos no Le ................................8

2.4. Decomposição, Efeitos nas Propriedades Físicas e Químicas do Solo e Critérios para o Uso Agronômico do Le ….......................................................................... 16

2.5. Metais Pesados no Sistema Solo-Planta-Animal .................................................2.

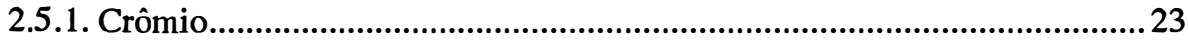

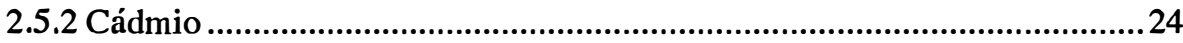

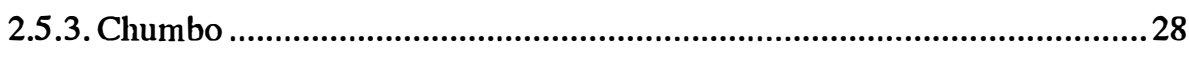

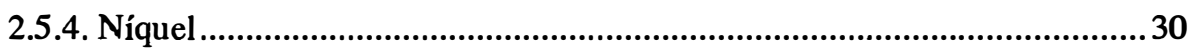

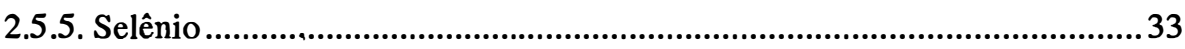

2.6. Respostas de Culturas a Adição de Le................................................................. 35

2.6.1. Culturas Alimentíceas ............................................................................ 35

2.6.2. Cana-de-Açúcar ....................................................................................... 39

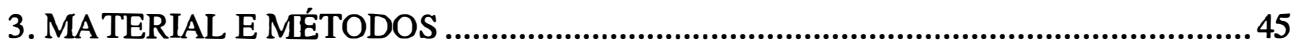

3.1. Características Gerais do Local, do Le e do Cultivar de Cana-de-Açúcar .............. 45

3.1.1. Localização ........................................................................................... 45 


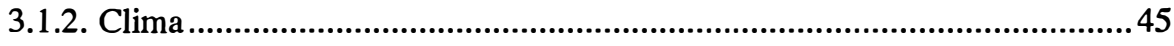

3.1.3. Características de Fertilidade do Solo e a Recomendação de Fertilizantes 46

3.1.4. Composição do Lodo de Esgoto ................................................................ 47

3.1.5. Cana-de-Açúcar .................................................................................. 48

3.2. Delineamento Experimental ............................................................................... 48

3.3. Tratamentos, Contagem do Número de Perfilhos, Amostragens de Solo e de Planta e

Preparo de Amostras.................................................................................. 48

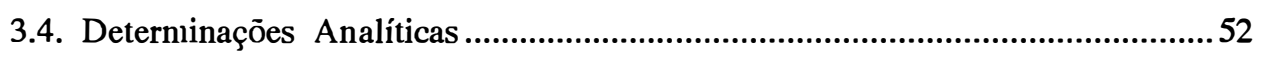

3.4.1. Características Agrotecnológicas .........................................................56

3.4.2. Nutrientes e Metais Pesados nas Amostras Vegetais ................................56

3.4.3. Análises Químicas do Solo .....................................................................58

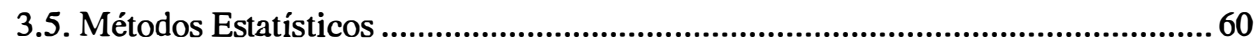

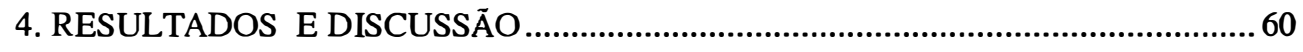

4.1. Condiçōes Agrometeorologicas durante o Experimento ..................................... 60

4.2. Lodo de Esgoto : Composição e Legislação............................................................ 60

4.3. Fertilidade do Solo e o Lodo de Esgoto ......................................................... 61

4.4. Metais Pesados no Sistema Solo-Planta e o Lodo de Esgoto ............................... 80

4.5. Efeito do Le no Estado Nutricional e no Estabelecimento da Cultura .................86

4.6. Efeitos do Le nas Produtividades, nas Características Tecnológicas e na Composição Química da Cana-de-Açúcar ..................................................... 99

4.7. Efeitos do Le nas Exportações de Espécies Químicas............................. 113

5. CONCLUSÕES ........................................................................................... 118

REFERÊNCIAS BIBLIOGRÁFICAS ............................................................... 120

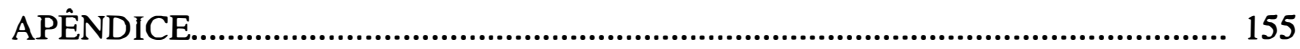


1 Influência da aplicação de doses de lodo de esgoto na acidez ativa (a = $\mathrm{pH}$ ) e potencial $(\mathrm{b}=\mathrm{H}+\mathrm{Al})$, teores de cálcio (c) e magnésio (d ) no solo, aos 146, 272 e 484 dap.

2 Influência da aplicação de doses de lodo de esgoto nos teores de potássio (a ), de bases (b), capacidade de troca catiônica (c) e saturação por bases (d) no solo, aos 146, 272 e 484 dap.

3 Influência da aplicação de doses de lodo de esgoto nos teores de fósforo (a), de zinco (b), de cobre (c), de boro (d) no solo, aos 146, 272 e 484 dap....65

4 Influência da aplicação de doses de lodo de esgoto nos teores de manganês (a ), de cádmio(b), de crômio (c) e chumbo(d ) no solo, extraidos por DTPA pH 7,3, aos 146, 272 e 484 dap.

5 Influência da aplicação de doses de lodo de esgoto na saturação de potássio (a) e teores de níquel (b ), de ferro ( c ) e enxofre (d ) no solo, aos 146, 272 e 484 dap ..........................................................................67

6 Influência da aplicação de doses de lodo de esgoto na acidez ativa ( $\mathrm{pH}=$ a), na soma $(\mathrm{SB}=\mathrm{b})$, e saturação de bases $(\mathrm{V} \%=\mathrm{c})$, capacidade de troca catiônica $(\mathrm{CTC}=\mathrm{d})$ e acidez potencial $(\mathrm{H}+\mathrm{Al}=\mathrm{e})$ no solo, com o decorrer do tempo (dap)

7 Influência da aplicação de doses de lodo de esgoto nos teores de boro(a), de manganês (b), de cálcio (c), de fósforo(d), de zinco(e) e na enxofre(f) no solo, com o decorrer do tempo (dap) 
Influência da aplicação de doses de lodo de esgoto nos teores de cádmio (a), de chumbo (b), de ferro (c), de níquel (d), de crômio (e) e cobre(f) no solo, com o decorrer do tempo (dap)

9 Influência das doses de lodo de esgoto ao solo, nos conteúdos foliares de zinco (a), de manganês (b), de selênio (c) e de níquel (d) na cana-planta, aos 146 e 272 dap

10 Influência das doses de lodo de esgoto ao solo, nos conteúdos foliares de enxofre(a), de cobre (b), de ferro(c), de boro (d) e de cádmio(e) na canaplanta, aos 146 e 272 dap

11 Influência da aplicação de doses de lodo de esgoto ao solo nos conteúdos foliares de magnésio(a), de fósforo(b), de cálcio(c) e de potássio (d) na cana-planta, aos 146 e 272 dap.

12 Influência da aplicação de doses de lodo de esgoto ao solo, no perfilhamento (a), no número de colmos industrializáveis por metro (b) e do fator perfilhamento (c) na cana-planta

13 Influência da aplicação de doses de lodo do esgoto ao solo, nas características tecnológicas (a), nas produtividades de biomassa (b) e de açúcar expresso em tha em pol (c) e em teórico recuperável (d) nos colmos da cana-planta, aos 469 dap.

14 Influência da aplicação de doses de lodo de esgoto ao solo, na exportação de nitrogênio, de potássio, de cálcio(a), de fósforo, de magnésio, de enxofre (b), de alumínio, de ferro, de sódio (c), de cobre, de boro, de selênio (d), de cádmio, de crômio e de níquel (e) pelos colmos+folhas da cana-planta, aos 431 dap

15 Influência da aplicação de doses de lodo de esgoto ao solo, na exportação de cobre, de boro, de zinco, de selênio(a), de cádmio, de crômio e de níquel (b), de fósforo, de calcio, de magnésio(c), de enxofre (d), de potássio (e) e de nitrogênio (f) pelos colmos da cana-planta, aos 472 dap...116 


\section{LISTA DE TABELAS}

Tabela

Página

1 Teores de elementos quínicos no Le do Brasil e da Europa ...................... 11

2 Teores médios em metais pesados do Le produzido em vários países e teores limites aceitos internacionalmente para a sua utilização na agricultura ............................................................................ 12

3 Conteúdos de metais pesados e quantidades adicionadas por $100 \mathrm{t} / \mathrm{ha}$ de Le (matéria seca) e teor máximo aceitável no solo.

4 Enriquecimento do solo após aplicação de 40 tha de Le (úmido)

5 Valor de correlação entre os perfilhos $/ \mathrm{m}$, colmos $/ \mathrm{m}$ e o fator perfilhamento (FP) com parâmetros químicos do solo, amostrados aos 272 dap

6 Valor de correlação entre os perfilhos $/ \mathrm{m}$, colmos $/ \mathrm{m}$ e o fator perfilhamento (FP) com teores de algumas espécies químicas nas folhas +3 , amostrados aos 272dap.

7 Valor de correlação entre as produtividades da cana-planta, expressas em colmos despontados colhidos aos 469 dap, em relação aos parâmetros químicos de solo, amostrados aos 272 dap

8 Valor de correlação entre as produtividades da cana-planta, expressas em colmos despontados colhidos aos 469 dap, em relação aos teores foliares de algumas espécies químicas, amostrados aos 272 dap 


\section{LISTA DE ABREVIATURAS}

$\begin{array}{ll}\text { Le } & =\text { Lodo de esgoto. } \\ \text { DBO } & =\text { Demanda Biológica de Oxigênio. } \\ \text { DQO } & =\text { Demanda Química de Oxigênio. } \\ \text { MS } & =\text { Matéria seca. } \\ \text { SABESP } & =\text { Companhia de Saneamento Básico do Estado de São Paulo. } \\ \text { EPA } & =\text { Agência Americana de Proteção ao Meio Ambiente. } \\ \text { dap } & =\text { dias após o plantio. }\end{array}$




\title{
USO AGRONÔMICO DE LODO DE ESGOTO: EFEITOS EM FERTHLDADE DO SOLO E QUALIDADE DA CANA-DE-AÇÚCAR
}

\author{
Autor : FÁBIO CESAR DA SLVA \\ Orientador : ANTONIO ENEDI BOARETTO
}

\section{RESUMO}

A presente pesquisa teve por objetivo avaliar os efeitos da aplicação de lodo de esgoto (Le), com e sem adição de fertilizante mineral , como agente modificador da fertilidade do solo (Podzólico Vermelho Amarelo), bem como, fornecedor de nutrientes e de metais pesados nele contidos na cana-de-açúcar e seus reflexos na maturação, nas produtividades agrotecnológicas e nas exportações destes elementos. Para tanto, foi montado ensaio de campo, em delineamento de blocos ao acaso com 15 tratamentos e 3 repeticões, constituidos pela combinação de três doses de Le $(0,20$ e 40 t/ha, peso úmido), com adubação NP, NK, PK e NPK (nas dosagens de 60, 80 e 100 $\mathrm{kg} / \mathrm{ha}$ de $\mathrm{N}, \mathrm{P}_{2} \mathrm{O}_{5}$ e $\mathrm{K}_{2} \mathrm{O}$, respectivamente) e sem adubação.

O Le foi analisado, obtendo-se $C=71^{\star}, N=22^{\star}, P=10^{\star}, A I=$ $2,0^{\star}, \mathrm{Ca}=11,5^{\star}, \mathrm{Mg}=3,5^{\star}, \mathrm{K}=2,0^{\star}, \mathrm{S}=10, \mathrm{Fe}=50^{\star}\left(^{*}=\mathrm{g} \cdot \mathrm{kg}^{-1} \mathrm{de} \mathrm{MS}\right), \mathrm{Cu}=$ $905^{\star \star}, \mathrm{Mn}=505^{\star \star}, \mathrm{Cd}=25^{\star \star}, \mathrm{Cr}=645^{\star \star}, \mathrm{Ni}=445^{\star \star}, \mathrm{Pb}=265^{\star \star}$ e $\mathrm{Zn}=1880^{\star \star}$ 
$\left({ }^{\star \star}=\mathrm{mg} \cdot \mathrm{kg}^{-1} \mathrm{de} \mathrm{MS}\right), \mathrm{pH}=10 \mathrm{e}$ a água $=620 \mathrm{~g} \cdot \mathrm{kg}-1 . \quad$ Para avaliar o efeito do Le na fertilidade do solo, foram retiradas amostras deste na camada de 0 a 20 cm em três épocas: aos 146, 272 e 484 dias após o plantio $\cdots a p)$. Nesta última época, efetuou-se a coleta do solo também na profundi ${ }^{\text {if }}$ de $20-50 \mathrm{~cm}$. As amostras de terra foram analisadas pelo sistema IAC e determinando-se S por turbidimetria extraído em $\mathrm{CaCl}_{2}(1,5 \mathrm{~g} . \mathrm{kg}-1)$. Os metais pesados $(\mathrm{Cr}, \mathrm{Cd}, \mathrm{Cu}$, Fe, Mn, Pb e Zn) foram extraídos do solo por solução de DTPA pH 7,3 (relação = 2:1) e determinados em espectrômetro de emissão atômica em plasma (ICP). As amostras de folhas de cana-de-açúcar foram colhidas aos 146 e 272 dap. Na colheita final, amostrou-se a parte aérea da cana-de-açúcar. Nos materiais vegetais, secos em estufa, foram determinados os nutrientes e metais pesados no ICP

O Le mostrou-se adequado como corretivo do complexo coloidal do solo e ainda como fertilizante para a cana-de-açúcar, principalmente como fonte de $\mathrm{Ca}, \mathrm{P}, \mathrm{S}$ e $\mathrm{Zn}$, o que refletiu em aumentos lineares de produtividades em biomassa e açúcar. Ressalta-se, entretanto, que os citados efeitos do Le foram de curta duração, ou seja, se restringindo-se a apenas 1 ano agrícola.

Houve aumentos nas exportações de $\mathrm{N}, \mathrm{Ca}, \mathrm{P}, \mathrm{Mg}, \mathrm{S}, \mathrm{Fe}$, $\mathrm{Cu}, \mathrm{B}$ e $\mathrm{Zn}$ pela parte aérea com a adição de Le, as quais foram condicionadas pelos maiores teores de $\mathrm{B}, \mathrm{Ca}, \mathrm{Cu}, \mathrm{S}$ e $\mathrm{Zn}$ no tecido vegetal e pela maior produtividade de biomassa. Comparando-se as quantidades exportadas de nutrientes pela parte aérea, com os valores adicionados dos elementos por $\mathbf{4 0}$ 
t/ha de Le, constata-se que o balanço foi positivo, exceto para o B e $\mathrm{K}$, cuja diferença foi negativa.

Os metais pesados não tiveram aumentos de seus teores nos colmos, devido ao uso do Le, pois eles foram da ordem de valor que não ofereceu qualquer risco de passagem à cadeia trófica. 


\title{
SEWAGE SLUDGE AGRONOMICAL USE : EFFECTS ON SOIL FERTILITY AND SUGAR CANE QUALITY
}

\author{
Author : FÁBIO CESAR DA SILVA \\ Advisor : ANTONIO ENEDI BOARETTO
}

\section{SUMMARY}

The present research aimed to evaluate the effects of the application of sewage sludge(SS), with and without addition of mineral fertilizer, on soil fertility, as well as on the utilization of nutrients and heavy metals in sugar cane and its reflexes on maturation, agrotechnological productivities and exportations of these elements. For this purpose a field assay was set up in random blocks delineation with 5 treatments and 3 replications, each one established by the combination of three doses of SS $(0,20$ and $40 \mathrm{t} / \mathrm{ha}$, wet weight) with NP, NK, PK and NPK fertilization ( 60, 80 and $100 \mathrm{~kg} / \mathrm{ha}$ of $\mathrm{N}, \mathrm{P}_{2} \mathrm{O}_{5}$ and $\mathrm{K}_{2} \mathrm{O}$, respectively) and without fertilization.

The chemical composition of SS was: $C=71 \mathrm{~g} \cdot \mathrm{kg}^{-1}, \mathrm{~N}=22$ g.kg ${ }^{-1}, P=10 \mathrm{~g} \cdot \mathrm{kg}^{-1}, \mathrm{Al}=2,0 \mathrm{~g} \cdot \mathrm{kg}^{-1}, \mathrm{Ca}=11,5 \mathrm{~g} \cdot \mathrm{kg}^{-1}, \mathrm{Mg}=3,5 \mathrm{~g} \cdot \mathrm{kg}^{-1}, \mathrm{~K}=2,0$ g. $\mathrm{kg}^{-1}, \mathrm{~S}=10 \mathrm{~g} \cdot \mathrm{kg}^{-1}, \mathrm{Fe}=50 \mathrm{~g} \cdot \mathrm{kg}^{-1}, \mathrm{Cu}=905 \mathrm{mg} \cdot \mathrm{kg}^{-1}, \mathrm{Mn}=505 \mathrm{mg} \cdot \mathrm{kg}^{-1}, \mathrm{Cd}=$ $25 \mathrm{mg} \cdot \mathrm{kg}^{-1}, \mathrm{Cr}=645 \mathrm{mg} \cdot \mathrm{kg}^{-1}, \mathrm{Ni}=445 \mathrm{mg} \cdot \mathrm{kg}^{-1}, \mathrm{~Pb}=265 \mathrm{mg} \cdot \mathrm{kg}^{-1}$ and $\mathrm{Zn}=1880$ $\mathrm{mg} \cdot \mathrm{kg}^{-1}, \mathrm{pH}=10$ and the water $=620 \mathrm{~g} \cdot \mathrm{kg}^{-1}$. To evaluate the effcts of SS on soil fertility, soil samples were collected from $0-20 \mathrm{~cm}$ layers in three times after 
the planting: 146, 272 and 484 dap (days after planting). In the last sampling soil was also collect from $20-50 \mathrm{~cm}$ depth. The soil samples were analysed by IAC method (resin), including $S$ extracted with $\mathrm{CaCl}_{2}(1,5 \mathrm{~g} \cdot \mathrm{kg}-1)$ and determined by turbidimetry. The soil heavy metals $(\mathrm{Cr}, \mathrm{Cd}, \mathrm{Cu}, \mathrm{Fe}, \mathrm{Mn}, \mathrm{Pb}$ and $\mathrm{Zn}$ ) were extracted with DTPA method and analysed by ICP spectrometry. The samples of sugar cane leaves were taken at 146 and 272 dap. In the last sampling, the above ground part of the sugar cane was collected. The materials were dried, ground and digested for analysis.

The SS showed to be suitable as amender of the soil colloidal complex and fertilizer to sugar cane as well, mainly as source of $\mathrm{Ca}, \mathrm{P}, \mathrm{S}$ and $\mathrm{Zn}$. There was linear increases in productivities of biomass and sugar (Tpol/ha and $\mathrm{TAH}$ ) by its increasing application rate. Emphasis should be done, however, that these results of SS were of short duration, i.e., restrained to only one agricultural year.

There were increases in $\mathrm{N}, \mathrm{Ca}, \mathrm{P}, \mathrm{Mg}, \mathrm{S}, \mathrm{Fe}, \mathrm{Cu}, \mathrm{B}$ and $\mathrm{Zn}$ exportations by above ground part with SS addition, which were conditioned by higher contents of $\mathrm{B}, \mathrm{Ca}, \mathrm{Cu}, \mathrm{S}$ and $\mathrm{Zn}$ in vegetable tissue and the greater productivity of biomass. Comparing the exported quantity of nutrients by the above ground part with the added amount of the elements through 40 t/ha of SS, the balance was positive, except for $B$ and $K$.

It was emphasized that the use of SS did not increase the heavy metal content in the stems, in order to cause a risk to trophic chain. 


\section{INTRODUÇÃO}

A adoção de tecnologia não sustentável tem como conseqüência a geração de resíduos, lançados ao meio ambiente, rios, atmosfera ou ao solo, na maioria das vezes. A problemática dos resíduos assume caráter dramático onde há concentração demográfica, a qual se originou do desenvolvimento industrial, do progresso econômico e das facilidades oferecidas nas cidades, tornando-as atrativas à população. Diante disso, os atuais desafios da ciência são, talvez, encontrar caminhos para propiciar o desenvolvimento tecnológico sustentado, o qual fundamenta-se em melhorar ou, pelo menos, manter a qualidade de vida da população em crescimento e em preservar o ambiente, acompanhado de mudanças tecnológicas e institucionais, com o objetivo de satisfazer as necessidades humanas das gerações presente e futura.

As águas servidas que são lançadas aos rios constituem o principal agente poluente, gerado onde existem altas densidades demográfica e industrial. Portanto, surge a necessidade de evitar a poluição dos rios e recuperar aqueles já comprometidos. A maneira de fazer isso é através do tratamento das águas servidas, do que origina o lodo de esgoto (Le), trazendo consigo as questões: onde depositálo? como usá-lo sem ocasionar impacto à qualidade ambiental? 
As opções para o emprego do Le são várias, destacando-se a simples deposição em aterros, a incineração, o bombeamento para os oceanos e a descarga em rios. Outrossim, estas alternativas não são indicadas sob o ótica do desenvolvimento sustentável.

O uso agronômico do Le é a alternativa de maior sustentabilidade, pois este resíduo é fonte de nutrientes e de matéria orgânica, podendo ser ainda um corretico da acidez do complexo coloidal e condicionador das propriedades físicas do solo. Alerta-se que o Le contem metais pesados $(\mathrm{Cd}, \mathrm{Zn}, \mathrm{Mn}, \mathrm{Cu}, \mathrm{Cr}, \mathrm{Ni}$ e $\mathrm{Pb}$ ), compostos orgânicos persistentes e patógenos, que podem entrar gradualmente e acumular-se na cadeia trófica animal, pois são absorvidos pelas plantas das quais estes se alimentam.

A questão básica para os pesquisadores é encontrar critérios para o uso de Le na agricultura, considerando a capacidade do solo em depurar a sua carga orgânica e o aproveitamento dos nutrientes nele contido pelas culturas. Estes aspectos vem sendo investigados há muito tempo em solos de clima temperado; todavia, tais resultados e recomendações não podem ser extrapolados para os solos ácidos dos trópicos.

A fim de definir os critérios para o emprego na agricultura de Le nos trópicos, deve-se conhecer a intensidade de mineralização desse material no solo, pois dela depende o suprimento de nutrientes que atenderão ou não as exigências nutricionais de determinada cultura. Este aspecto determinará a quantidade de resíduo a ser reciclado por ano, numa determinada área de solo, ao passo que, os teores de metais pesados definirão o número máximo de anos que o solo poderá ser 
usado como local de deposição do Le. Face aos insuficientes conhecimentos dos processos físicos e químicos relacionados ao material orgânico e da dinâmica dos metais pesados adicionados pelo Le em solos de clima tropical, há controvérsias quanto a possibilidade de utilizá-lo como fertilizante para cultura de cana-de-açúcar, resumidas nas perguntas que se seguem:

- Qual é o potencial de liberação ao solo das espécies quimicas contidas no Le, e quais são os seus reflexos na absorção dos nutrientes e dos metais pesados e ainda, na produtividade da cultura?

- Qual é o risco dos metais pesados do Le acumularem-se no sistema solo-plantaatmosfera?

Diante do exposto, formulou-se a hipótese: se o Le traz melhorias ao complexo coloidal e aumenta a disponibilidade dos nutrientes no solo e, se não ocorrer a passagem de metais pesados para a cadeia trófica animal, a ponto de provocar efeitos deletérios, então poderá ser considerado um fertilizante adequado para o uso na cultura de cana-de-açúcar.

Tendo em vista a hipótese formulada, o objetivo desta pesquisa foi avaliar, em condições de campo, os efeitos da aplicação de doses de Le, complementado ou não com nitrogênio, fósforo e potássio, sobre as propriedades químicas de um Podzólico Vermelho Amarelo, bem como seus reflexos na maturação, nas produtividades biológica e econômica da cana-de-açúcar e na absorção de nutrientes e de metais pesados, por esta cultura. 


\section{REVISÃO DE LITERATURA}

\subsection{Generalidades}

As alternativas para propiciar desenvolvimento tecnológico sustentável que passa pela proteção dos rios que cortam as grandes cidades, pelo tratamento das águas servidas é encontrar-se uma disposição final adequada dos resíduos gerados. Todavia, não é suficiente apenas evitar o descarte dos resíduos nos rios e oceanos, pois no sudeste brasileiro vários deles já estão poluídos. Por exemplo, na cidade de São Paulo, o rio Tietê e seus afluentes Pinheiros e Tamanduatei são verdadeiros esgotos a céu aberto, tornando-se necessário despolui-los, através do tratamento dos esgotos que nele são lançados, o que deverá resultar na produção de quantidade considerável de lodo de esgoto (Le). Ressalte-se ainda que o desequilíbrio ecológico provocado pelo descarte de resíduos urbanos e industriais, especialmente em rios e locais públicos, tem gerado insatisfação e pressão social bastante justificadas, tornando importante pesquisar alternativas que sejam sustentadas ao longo do tempo para a disposição final destes materiais (BATAGLIA et al., 1983a).

Para minimizar os efeitos ambientais negativos do descarte de resíduos urbanos e industriais sem qualquer pré-tratamento, é fundamental proceder-se o tratamento dos esgotos, visando essencialmente a redução do seu potencial poluidor. 
Do tratamento dos esgotos, obtém-se o Le. Este tratamento consiste na separação da fração sólida da líquida e é efetuado pela combinação de processos físicos, químicos e biológicos (SABESP, 1979).

O problema gerado neste sistema de tratamento das águas servidas é a disposição final do Le obtido, visto que isto representa de 30 a $40 \%$ dos custos operacionais (BETTIOL et al., 1983).

As alternativas possiveis para a disposição final do Le são as seguintes, à nível mundial:

a. disposição em aterros sanitários, o que é bastante aceitável tecnicamente, porém, com custos de manutenção proibitivos (ESTADOS UNIDOS, 1980);

b. despejo nos oceanos, rios e lagos, o que é proibido por lei nos Estados Unidos, devido ao grande impacto ambiental (ESTADOS UNIDOS, 1980);

c. incinerações, o que apresenta limitações por gerar gases poluentes para a atmosfera e por não ser econômico e,

d. compostagem ou emprego direto como adubo, o que parece ser o caminho mais viável.

Segundo CARVALHO \& BARRAL (1981), com a aplicação de Le ao solo há reciclagem de nutrientes vegetais, com economia de fertilizantes e tornando mais sustentado o sistema de produção agrícola. A produção prevista de 2.000 t/dia de Le, com base no material seco, nas estações de tratamento da grande São Paulo, conterá 20 t/dia de $\mathrm{N}, 50$ t/dia de $\mathrm{P}_{2} \mathrm{O}_{5}, 6$ t/dia de $\mathrm{K}_{2} \mathrm{O}$ e 1.200 t/dia de matéria orgânica. Se comparar com o gasto de energia para produzir o fertilizante 
correspondente, representarão economia equivalente a 100.000 barris/ano de petróleo, num valor potencial de três milhões de dólares (IPT/CETESB, 1983).

O Le, em países industrializados, tornou-se um fertilizante opcional para diversas culturas, havendo o monitoramento dos seus efeitos no solo e na nutrição das plantas. A quantidade máxima de Le aplicada ao solo anualmente é limitada pelas exigências nutricionais das culturas, ao passo que as quantidades de metais pesados nele existentes definem o tempo de aplicação, em número de anos, suportado pelo solo (MULCHI et al., 1987).

A revisão de literatura foi organizada visando oferecer subsídios para a discussão dos resultados experimentais. Inicialmente é descrito, de modo sucinto, a obtenção do Le usado no ensaio. Em seguida, caracteriza-se o Le, nos aspectos físico e químico e a presença de patógenos. Na seqüência, apresenta-se os possiveis efeitos do Le no solo, e como se poderia atenuar os problemas nele existentes ao ser descartado, abrangendo: decomposição, patógenos, reações e a possibilidade da passagem de metais pesados para a cadeia trófica. Para finalizar a revisão, apresentam-se os resultados experimentais sobre a utilização do Le como fertilizante nas culturas alimentícias e cana-de-açúcar, principalmente aqueles conduzidos em solos ácidos e clima tropical.

\subsection{Tratamento do Esgoto para Obtenção do Le em Barueri-SP}

O sistema de tratamento básico ou primário de esgoto consta, de modo sucinto, em captar as águas servidas e torná-las livres dos sólidos grosseiros, os 
quais são retidos em grades fixas de malhas grosseira e média, sendo removidos tais sólidos por sistemas de rastelos de acionamento automático. Em seqüência, o material passa por uma caixa de areia, sofrendo desarenação. Posteriormente à desarenação, o esgoto é bombeado para os decantadores primários, onde haverá a separação do lodo cru (material mais denso) e do efluente. O lodo cru, com $2 \%$ de sólidos, é concentrado a $8 \%$ nos adensadores, seguindo para os digestores. 0 efluente passa pelos aeradores, onde ocorrerá a incorporação da matéria orgânica em suspensão, pela ação de microrganismos aeróbicos,. Após esta etapa, o material é bombeado para os decantadores secundários, onde haverá o fracionamento em lodo pré-tratado ou primário, que já sofreu redução em até $40 \%$ do potencial poluidor, e em efluente secundário. O efluente, agora despoluido, vai para o rio Tietê, e o lodo pré-tratado é misturado com lodo cru nos digestores, ocorrendo sua decomposição e conseqüente produção de metano, e um Le, que será concentrado em centrífuga e filtro-prensa até $60 \%$ de umidade (SABESP, 1979 e SANTOS, 1979). Este resíduo final, empregado na presente pesquisa, sofreu remoção de 80 a $95 \%$ do potencial poluídor (avaliado pela DQO), em relação ao lodo cru (VAZOLLÉR et al., 1989).

O Le tem sua matéria orgânica modificada em relação à sua matéria prima, pois esta é degradada e transformada em outros compostos pela ação de vários tipos de bactérias, e por fungos e leveduras incorporando-se, em sua maior parte, à biomassa microbiana (VAZOLLÉR et al., 1989 e PIKE \& CARRIGTON, 1972). 


\subsection{Composição Química, Física e Presença de Patógenos no Le}

A qualidade do Le está intimamente relacionada ao nivel sócio-cultural do povo (CARVALHO, 1982) pois, em última análise, os componentes que os formaram são resultantes dos hábitos alimentares, saneamento básico, saúde e ainda, do estágio de desenvolvimento industrial. A composição química do Le, de acordo com SOMMERS (1977) e FORTUNY \& FULLeR (1979), è bastante heterogênea, em função das matérias-primas que o constituiram, isto é, depende basicamente da origem dos residuos serem mais domésticos ou industriais. Na Tabela 1 é dada a amplitude de variação na composição do Le, obtida pela SABESP no Brasil ( BOARETTO, 1986; IPT/CETESB, 1983; SILVA et al., 1995; entre outros) e na Europa (COTTENIE, 1991).

Quando o Le é proveniente de estações de tratamento das águas servidas, com predominância de esgotos domésticos sobre os industriais, os niveis de $\mathrm{Cd}, \mathrm{Cu}, \mathrm{Mo}$, $\mathrm{Ni}, \mathrm{Zn}$ e $\mathrm{Pb}$, além de $\mathrm{Mn}, \mathrm{Fe}, \mathrm{Al}, \mathrm{Cr}$ e $\mathrm{Hg}$, entre outros menos freqüentes, permanecem dentro das faixas aceitáveis para o seu uso agronômico (GALLOWAY \& JACOBS, 1977).

Entretanto, devido à presença de metais pesados, a situação é inversa, ocasião em que o Le tem restrições para fins agrícolas. Para o Le proveniente das estaçō̇es de tratamento localizadas nas cidades do $\mathrm{ABC}$ paulista, onde prevalecem efluentes industriais com altos teores de metais pesados, a melhor forma de disposição encontrada foi a sua sinterização, produzindo agregado leve utilizado na construção civil (BETTIOL et al., 1983).

Em geral, o Le pode fornecer nitrogênio às plantas em quantidades satisfatórias, além de outros elementos como fósforo, cálcio, magnésio, zinco, cobre 
e manganês. A composição média dos Le dos Estados Unidos, expressa em g. $\mathbf{~}^{-1}$ de MS, é de cerca de 40 de nitrogênio, 20 de fósforo, 4 de potássio e 250 de carbono (ESTADOS UNIDOS, 1980). Estes são mais ricos em macronutrientes que o Le produzido pela SABESP. A maioria dos nutrientes no Le está na forma orgânica, como é destacado por SABEY (1980), embora apenas cerca de 30 a $50 \%$ do nitrogênio total estejam na forma prontamente aproveitável pelas plantas. O fósforo encontra-se $70 \%$ na forma orgânica, possivelmente aproveitável no primeiro ano de cultivo, sendo que a maior parte do potássio é prontamente disponivel aos vegetais. WALSH (1979) acredita que, em condições de clima temperado, estes nutrientes, contidos no Le, têm uma vantagem adicional em relação aos mesmos na forma de fertilizantes químicos, pois seriam liberados ao solo no decorrer do ciclo da planta, reduzindo dessa forma a lixiviação. Todavia, essa liberação, dita mais lenta, dos nutrientes pelo Le, plenamente válida nas condições temperadas, pode não ser verdadeira em solos tropicais, onde a degradação da carga orgânica é mais rápida. Neste caso, a introdução de qualquer resíduo na forma orgânica ou inorgânica parece ser de pouco importância (PARAZZl et al., 1984). Quando se pretende aplicar - Le no solo como fertilizante, é necessário ter conhecimento prévio de sua composição química para se calcular a dose a ser recomendada.

O Le obtido pela SABESP (Tabelas 1 e 2) não apresenta, para a maioria dos metais pesados, teores acima dos limites estabelecidos na Legislação para o uso agrícola adotado pelo nordeste dos Estados Unidos (BAKER et al., 1985); o níquel estaria freqüentemente acima do aceitável e o cobre e cádmio quase atingiriam o limite máximo estabelecido pela citada Legislação. Entretanto, o teor de 
niquel no Le não seria problema, se fossem adotadas as novas especificações estabelecidas pela Agência Americana de Proteção ao Meio Ambiente (EPA) para o uso e disposição agricola do resíduo, definidas no Registro Federal de 19/03/1993 (53 FR [32]: 9248-9415) na 40CFR parte 503. Assim, o teor de Ni do Le estaria, na maioria das vezes, abaixo do limite máximo que é de $420 \mathrm{mg} \cdot \mathrm{kg}^{-1}$ de MS. O registro de 1993 da EPA é mais tolerante e ampliou também os limites para diversos outros metais pesados, o que possibilita maior volume de Le que poderá ser empregado na agricultura. Outrossim, observa-se que o Le produzido pela SABESP tem teores de niquel e de cádmio acima dos valores estabelecidos pelas Legislações Holandesa e Escocesa (Tabelas 1 e 2), que são mais rígidas do que a dos Estados Unidos definida pela ESTADOS UNIDOS - EPA (1993). Tal fato se deve, provavelmente, por que estes paises têm uma oferta, comparativamente aos Estados Unidos, mais reduzida de resíduos e uma extensão mais limitada de terras agricultáveis onde poderá ocorrer o uso do Le.

Para o aproveitamento do Le na agricultura, existem dois problemas a serem solucionados: a presença de microorganismos patogênicos e as elevadas concentrações de metais pesados. Para MOREL (1978) e CARVALHO \& BARRAL (198I), deve ser dada atenção especial ao perigo devido à presença de agentes patogênicos causadores de doenças, além da presença de compostos tóxicos e metais pesados, que podem acumular-se nos alimentos (BETTIOL et al., 1983; IPT/CETESB, 1983) e serem ingeridos pelo homem e animais, com graves riscos para à saúde./Além dos problemas anteriores, WALKER (1975) e KEEFER et al. (1979), acrescentam-se os problemas do mal odor e da possibilidade dos patógenos contaminarem os recursos hídricos. 
Tabela 1 - Teores de elementos químicos no Le do Brasil e da Europa.

\begin{tabular}{lccc}
\hline & Brasil $^{1}$ & Europa $^{2}$ & Limite máximo $^{3,4}$ \\
\hline $\mathrm{N}\left(\mathrm{g} \cdot \mathrm{kg}^{-1}\right)$ & $8-40$ & 20 & $40^{(3)}$ \\
$\mathrm{P}\left(\mathrm{g} \cdot \mathrm{kg}^{-1}\right)$ & $4-40$ & 20 & $16^{(3)}$ \\
$\mathrm{K}\left(\mathrm{g} \cdot \mathrm{kg}^{-1}\right)$ & $1-12$ & 5 & $34^{(3)}$ \\
$\mathrm{Ca}\left(\mathrm{g} \cdot \mathrm{kg}^{-1}\right)$ & $10-60$ & 30 & - \\
$\mathrm{Mg}\left(\mathrm{g} \cdot \mathrm{kg}^{-1}\right)$ & $1-5$ & 8 & - \\
$\mathrm{S}\left(\mathrm{g} \cdot \mathrm{kg}^{-1}\right)$ & $2-6$ & 5 & - \\
$\left.\mathrm{Fe} \mathrm{(g.kg}{ }^{-1}\right)$ & $20-30$ & $2-42$ & - \\
$\mathrm{Zn}\left(\mathrm{mg} \cdot \mathrm{kg}^{-1}\right)$ & $500-4000$ & $500-20000$ & $2500^{(4)}$ \\
$\mathrm{Cu}\left(\mathrm{mg} \cdot \mathrm{kg}^{-1}\right)$ & $400-3500$ & $1-3000$ & $1000^{(4)}$ \\
$\mathrm{Mn}\left(\mathrm{mg} \cdot \mathrm{kg}^{-1}\right)$ & $200-850$ & $50-2500$ & - \\
$\left.\mathrm{Al} \mathrm{(mg.kg}{ }^{-1}\right)$ & $20000-75000$ & - & - \\
$\mathrm{Cd}\left(\mathrm{mg} \cdot \mathrm{kg}^{-1}\right)$ & $5-30$ & $0-300$ & $25^{(4)}-35^{(3)}$ \\
$\mathrm{Pb}\left(\mathrm{mg} \cdot \mathrm{kg}^{-1}\right)$ & $50-800$ & $50-5000$ & $1000^{(4)-1} 400^{(3)}$ \\
$\mathrm{Cr}\left(\mathrm{mg} \cdot \mathrm{kg}^{-1}\right)$ & $70-400$ & $10-5000$ & $700^{(3)-1} 000^{(4)}$ \\
$\mathrm{Ni} \mathrm{(mg.kg}$ & $10-1300$ & $200^{(4)}$ \\
\hline & $150-600$ & &
\end{tabular}

Fonte: ${ }^{1}$ BOARETTO (1986), BETTIOL et all. (1983), IPT/CETESB (1983) e SILVA et al. (1995), usando o Le da SABESP; ${ }^{2}$ COTTENIE (1981); ${ }^{3}$ Limites máximos de teores de metais pesados para sua utilização na agricultura pela Legislação Inglesa e ${ }^{4} B A K E R$ et al. (1985) na Legislação adotada no Nordeste dos Estados Unidos. 
Tabela 2. Teores médios em metais pesados do Le produzido em vários países e teores limites aceitos internacionalmente para a sua utilização na agricultura.

\begin{tabular}{crrrrrr}
\hline Metais & \multicolumn{3}{c}{ Composição média } & \multicolumn{3}{c}{ Limites Aceitos $^{(2,3)}$} \\
\cline { 2 - 7 } Pesados & a & b & c & a & d & e \\
\hline B & 37 & 70 & - & - & - & - \\
Cd & 104 & $<200$ & 40 & 85 & 10 & 20 \\
Cr & 1440 & 980 & 870 & 3000 & 500 & 2000 \\
$\mathrm{Cu}$ & 1346 & 970 & 1600 & 4300 & 600 & 1500 \\
$\mathrm{Mn}$ & 194 & 500 & 2660 & - & - & - \\
$\mathrm{Ni}$ & 235 & 510 & 380 & 420 & 100 & 25 \\
$\mathrm{~Pb}$ & 1832 & 820 & 1700 & 840 & 500 & 1500 \\
$\mathrm{Zn}$ & 2132 & 4100 & 6140 & 7300 & 2000 & 2500 \\
\hline
\end{tabular}

a= Estados Unidos; $\mathbf{b}=$ Reino Unido; $\mathbf{c}=$ Canadá $; \mathbf{d}=$ Holanda $; \mathrm{e}=$ Escócia FONTE: (1)ADRIANO (1986) ; (2)USDA / EPA, Registro Federal - (1993) e (3) MALAVOLTA (1994).

O principal aspecto relacionado com os metais pesados do Le para uso agronômico é saber as quantidades aceitáveis destes metais que podem ser aplicados no solo anualmente. Têm-se as seguintes teorias básicas que definem as doses recomendadas : a) equação de $\mathrm{Zn}$ equivalente; b) relação $\mathrm{Zn}-\mathrm{Cd}$; c) quantidade acumulada, com o tempo, de metais pesados no solo aplicados na forma de Le.

Os autores norte-americanos da década de 70 acreditavam que fitotoxidez pela aplicação de Le, era devido aos teores mais elevados de metais pesados (Cd, Ni e $\mathrm{Zn}$ ) nele contidos. Essa fitotoxidez teria sua intensidade mantida em proporcionalidade entre os diferentes teores críticos para o $\mathrm{Cd}$, Ni e $\mathrm{Zn}$ no solo 
adicionados na forma de Le, o que possibilitaria expressar o grau de dano as plantas que seria o equivalente a causado por uma concentração conhecida e tóxica de zinco (Equivalente de $\mathrm{Zn}$ ). VALADARES et al. (1983), demonstraram que a teoria do $\mathrm{Zn}$ equivalente não foi válida, quando empregada a diferentes solos e distintas espécies vegetais. Verificaram que a teoria não era correta porque o $\mathrm{Cd}$, Ni e $\mathrm{Zn}$ tinham solubilidades diferentes, em função de $\mathrm{pH}$ do solo, e as plantas tinham distinta tolerância aos mesmos.

No tocante à teoria referente ao efeito fitotóxico proporcional a relação $\mathrm{Zn} / \mathrm{Cd}$ pressupõem que o dano às plantas manteriam uma razão de teores de $\mathrm{Zn}$ e Cd no solo. Entretanto, foi verificado que as espécies vegetais toleram teores de $\mathrm{Zn}$ mais altos diferenciados pelos cultivares, mas o Cd já em pequeno valor torna-se sempre limitante para o desenvolvimento das plantas (GALLOWAY \& JACOBS, 1977). SOMMERS (1977), constatou que os metais têm reações distintas no solo, sendo eles influenciados diferentemente pelas propriedades químicas e físicas. Portanto, como as duas primeiras teorias não consideram a reação diferenciada\$̣ dos metais no solo verifica-se que não são válidas.

Tendo em vista o exposto, tem sido adotada pela comunidade científica a terceira teoria, ou seja, o principio que leva em conta a acumulação dos metais pesados no aḿbiente. Esta teoria norteou a confecção da Legislação dos ESTADOS UNIDOS - EPA (1993), a qual definiu as quantidades máximas de metais a serem aplicados anualmente ao solo. A legislação norte americana fundamentou-se no pressuposto que limitando-se a quantidade máxima diferenciada para os metais pesados na forma de Le ałp ser aplicada anualmente ao solo, estar-se-ia evitando que 
os metais possam se acumular no meio ambiente. Cabe ainda ressaltar que a citada Legislação não considera o efeito fitotóxico dos metais, pois não se têm ainda definidos os niveis no tecido vegetal que podem causar a citada toxidez nas diferentes espécies. Esse assunto está ainda em aberto, mas já existem algumas tentativas neste sentido, como a de CHANG et al. (1992).

Do ponto de vista da forma física, de acordo com MERRIL et al. (1969), o Le pode ser pastoso, semi-sólido ou seco, sob cujas formas poderia ser comercializado como fertilizante orgânico. Porém, SANTOS (1979) qualifica o Le ativado, digerido e seco pelo calor, como a forma física mais adequada para o manuseio e utilização como adubo, isolado ou misturado com outros fertilizantes.

No tocante aos patógenos do Le, ANDERSON et al. (1972) e FAO (1978), agrupa-os em : a) ovos de verme; b) bactérias; c)quistos de protozoários; e (d) vírus. A contaminação do Le por estes agentes patogênicos é tanto maior quanto menores forem o grau de tratamento dos esgotos e de depuração de sua carga orgânica. Vários processos são usados para eliminação ou redução dos agentes patógenos presentes no Le, segundo SABEY(1980) e IPT/CETESB (1983), citando-se : digestões aeróbica e anaeróbica, irradiação, compostagem, cloração, misturas com óxido de cálcio, calcário ou com residuos de indústria de cimento. Todavia, dentre as técnicas propostas, as mais aplicáveis ao Le seriam três.

A primeira, proposta por BETTIOL et al. (1983), é o controle de patógenos provocada pelà fabricação dos fertilizantes organo-minerais. Neste processo, o controle se dá pelo aumento da pressão osmótica advinda da adição dos sais fertilizantes, pela alta temperatura que ocorre no leito fluidizado e pela desidratação do produto final. A 
segunda maneira foi proposta por LOGAN \& MATTIAZZO-PREZOTTO (1992), que recomendaram a mistura do Le com resíduo de fomos da indústria de cimento (CKS), que contém $\mathrm{CaCO}_{3}$ obtendo, deste modo, um produto livre de patógenos, se for adicionado o CKS na proporção de $35 \%$ em peso, devido a desidratação do mesmo. A ultima proposta da FAO (1978), a compostagem do Le é a única altemativa que resulta em um controle adequado dos microrganismos nele presente. Ressalte-se que as duas ultimas altemativas não tem comprovação experimental.

DEAN \& SMITH (1973), chamou atenção para a composição microbiológica do Le da Europa, principalmente a presença das espécie Escherichia coli, associada às bactérias fecais, e parasitas como Helmintos, Ascaris lumbricóides e outros). O aspecto sanitário do Le, no caso específico do Brasil, pressupõem-se que é mais sério que em paises europeus, porque o meio favorece a proliferação de microorganismos patogênicos, devido o clima tropical e os niveis precários de tratamento dos esgotos e da saúde pública. A composição microbiológica do Le da SABESP avaliada por BETTIOL et al. (1983), foi a seguinte: Coliformes fecais $=4,1 \times 10^{10} \mathrm{NMP} / 00 \mathrm{~g}$ de peso seco; Streptococus

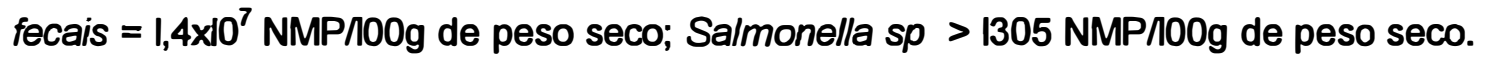
BERTON (1992), relata a presença de bactérias causadoras de febre tifóide e da cólera, de desinteria e de gastroenterite. Entre as doenças causadas por virus, as mais preocupantes incluem os agentes causais da pólio e hepatite viral.

Em relação a tempo de sobrevivência de diversos patógenos contidos no Le no sistema solo-planta, evidencia-se a persistência de helmintos e bactérias em períodos de anos, sendo que os ovos de Ascanis lumbricóides são bem resistentes à 
destruição no solo e onde podem persistir por sete anos, e se ingeridos pelo homem provocam a sua ação parasita ( ANDERSON et al., 1972; PAGE, 1983 e FAO, 1978).

Dentre as práticas visando contomar o problema, BERTON (1992), recomenda que o consumo de plantas arbustivas (cultura do algodão) somente ocorra um mês após a aplicação do Le. No caso de hortaliças, o autor recomenda que o Le não seja empregado na adubação das mesmas. Entretanto, MILLER et al. (1979) acrescenta que, deve-se manter um tempo de carência após aplicação de Le que é 1 ano, no mínimo, para se cultivar hortaliças.

\section{4. Decomposição, Efeitos nas Propriedades Físicas e Químicas do Solo e Critérios para Uso Agronômico do Le.}

A facilidade de degradação dos residuos, de acordo com VERSTRAETE \& VAERENBER (1986), pode ser avaliada pela relação entre DQO e DBO. Quando esta relação é próxima da unidade, como no caso do Le, cujo valor está ao redor de 2, o material é rapidamente biodegradável. Já as relações maiores que 5 indicam que o resíduo é de difícil biodegradação, por conter moléculas orgânicas que resistem ao processo de tratamento do esgoto e se concentram.

Quando se aplica Le ao solo modifica-se a dinâmica de nutrientes pela mudança na atividade biológica, constituida majoritariamente de bactérias (1 bilhão/g de solo), seguidas dos actinomicetos (aproximadamente 10 milhões/g). Os fungos constituem geralmente a maior porção da biomassa, cerca de duas a três vezes as bactérias e os actinomicetos, por causa da dimensão maior de suas hifas, porém, a 
população de bactérias ocorre em maior número. Esses microrganismos do solo contribuem para a reciclagem e decomposição do material orgânico (CARDOSO, 1992). As ações dos microrganismos do solo sobre o Le foram resumidas por MILLER et al. (1979), da seguinte maneira : (a) decompõem os compostos orgânicos; (b) atenuam alguns problemas potenciais do Le, como residuos de detergentes, pesticidas e hidrocarbonetos de petróleo; (c) reduzem os microrganismos patogênicos; (d) participam nos ciclos do nitrogênio, fósforo e enxofre; (e) atuam nas reações que influenciam a solubilidade e mobilidade de ions inorgânicos no solo.

Do ponto de vista das propriedades físicas do solo, o Le pelo efeito da matéria orgânica nele contida, refletiu em melhoria da estrutura do solo, aumentando a agregação das partículas, favorecendo assim a infiltração da água no perfil, a aeração e a retenção da água, conforme foi encontrado por vários autores (SABEY, 1974; BETTTIOL et al., 1983 e CARVALHO \& BARRAL, 1981). Todavia, FLAIG (1975), SACCHI \& BERNARDES (1983) e BERNARDES (1982), relatam que os beneficios nas propriedades físicas do solo resultariam em maiores produtividades agrícolas, desde que se aplique os adubos orgânicos em doses que sejam superiores à 10 tha.

No sistema solo-planta, quando os resíduos são aplicados, ocorrem diversas reações de importância e que podem ser agrupadas generalizadamente em dois tipos: reação de oxi-redução e reação de ácido-bases, mas na prática ambas reações se interagem, o que tornando- o muito mais complexo. Os valores das constantes de solubilidade e de estabilidade de quelatos ou complexos de um ín específico, que teoricamente pode se formar, são informações úteis e necessárias de serem conhecidas, mas não suficientes para se prever o comportamento de uma 
espécie química em particular num sistema tão complexo. Nestes casos, lança-se mão de recursos computacionais utilizando-se de "softwares" específicos para tais cálculos, como o GEOCHEN e MINEQL (BERTON, 1992).

A principal influência dos resíduos nas propriedades químicas do solo é a alteração do seu complexo coloidal ( CTC), pela introdução de cargas negativas contidas na porção orgânica do Le e enriquecendo-o em cátions básicos (Ca e Mg). BERTON et al.(1989) e de DIAS (1994), verificaram que os efeitos iniciais do Le incorporado ao solo era elevar o pH e reduzir os teores de alumínio trocável, caso este elemento esteja presente. Constataram ainda que a intensidade de alteração da acidez do solo pelo Le foi inversamente proporcional ao poder de tamponamento do seu complexo coloidal, ou seja, quanto maiores os teores de argila e de óxidos de ferro e alumínio, tanto maior era a resistência à mudança de pH (BERTON et al.,1989). MELO \& MARQUES (1992) verificaram que a CTC do solo sofreu uma elevação até 230 dias após a sua aplicação, devido a introdução ao solo de cargas negativas contidas no Le (MELLO et al., 1988), decrescendo em seguida. Em dose de 32 t/ha de Le, MELO et al.(1994), verificaram que houve correlação significativa entre a CTC do solo e a fração húmina da matéria orgânica, por um período de 230 dias após sua aplicação. A partir deste periodo, a correlação não foi significativa, talvez porque a fração húmina sofreu polimerização e não mais contribuiu com cargas para a CTC.

Os aumentos do pH do solo no tempo motivados pela adição de matéria orgânica em geral, foram explicados por GLORIA(1992), como decorrentes da liberação de elétrons pela oxidação do carbono, os quais podem ser recebidos pelo $\mathrm{O}_{2}$ ou $\mathrm{H}^{+}$, resultando na neutralização direta da acidez (no caso do $\mathrm{H}^{+}$) ou indiretamente, através da 
geração de ions oxigênio que se combinariam com os ions $\mathrm{H}^{+}$, formando água. Entretanto, na literatura de GOTO (1983), indicaram o Le inicialmente como agente acidificante de solo.

O Le tem participação importante como fonte de nutrientes para o solo. SABEY (1974) e CUNNINGHAM et al. (1975), relataram que a aplicação de Le promoveu aumento da disponibilidade de $\mathrm{N}$ no solo. Segundo CAST (1980), apenas $40 \%$ do nitrogênio contido no Le tomam-se disponiveis no primeiro ano após a aplicação. 0 efeito de Le como fonte de $\mathrm{P}$ aos vegetais foi explicado por dois aspectos: aumento da quantidade diretamente disponivel de $\mathrm{P}$, devido à simples presença dele no resíduo ( CABRE et al. , 1990 e AYUSO et al., 1992), e a ação indireta melhorando as propriedades químicas do solo ( CARVALHO \& BARRAL, 1981). O Le atuou ainda como fonte de S (SABEY, 1974) e de micronutrientes ( $\mathrm{Zn}$ e $\mathrm{Cu}$ ) para o solo (BETTIOL \& CARVALHO, 1982 e BERTON, 1992).

Verificou-se que a aplicação de Le em doses elevadas (160 t/ha), incorporadas a $60 \mathrm{~cm}$ de profundidade no solo, promoveu restrição ao crescimento do centeio cultivado a seguir, fitotoxidez que poderia ser devido ao excesso de N, P, Zn, $\mathrm{Cd}$ e $\mathrm{Ni}$, à formação de amônia e ao baixo teor de oxigênio no solo, decorrente da decomposição anaeróbica do Le (WALKER \& WILSON, 1973). Dentre as supostas causas da fitotoxidez causada pelo uso de Le em doses altas, encontram-se os metais pesados ( $\mathrm{Cd}, \mathrm{Ni}, \mathrm{Pb}$ e $\mathrm{Se})$, que são, por definição aqueles elementos da tabela periódica que tem densidade maior que 5,0 (MATTIAZZO-PREZOTTO, 1994).

O Le para o uso agrícola não pode ter concentrações altas de $\mathrm{Cd}, \mathrm{Cu}$, $\mathrm{Zn}$, Ni e $\mathrm{Pb}$, pois estes podem ser absorvidos pelas plantas e então ser transferidos 
para os alimentos (LOGAN \& CHANEY 1983). Tais considerações podem ser deduzidas dos dados de COTTENIE (1981), inseridos na Tabela 3, onde se verifica o enriquecimento do solo com diversos metais pesados após aplicação de Le na dose de 100 t/ha, em base seca, destacando-se principalmente o risco representado pelo cádmio. Ressalte-se que os teores máximos de metais pesados tolerados nos solos que receberam Le e apresentados na Tabela 3, foram estabelecidos pela Maine Department of Environmental Protection e apresentam valores maiores para o $\mathrm{Cd}$, $\mathrm{Cu}, \mathrm{Pb}$ e $\mathrm{Zn}$ (PEPIN \& COLEMAN, 1984), do que os valores propostos por COTTENIE (1981).

Nos ESTADOS UNIDOS (1993), a dose máxima de Le a ser aplicada ao solo é determinada pelo metal pesado que estiver em teor mais próximo do limite máximo aceitável pela referida legislação, mas no Brasil este aspecto ainda está em aberto. As Legislações encontradas na literatura não consideram a interferência das propriedades físicas, químicas e biológicas do solo na dinâmica dos metais pesados, mas consideram apenas que estes devem ter o pH mínimo de 6,5 para serem aptos a receber o Le. LOGAN \& CHANEY (1983), consideram que a propriedade capacidade de troca catiônica do solo pode ser usada para estabelecer a dose máxima de metais pesados a serem aplicados na forma de Le, pois sabe-se que a CTC condiciona em última análise, a retenção destes metais pelo complexo coloidal. Embora, os autores dividiram os solos em três intervalos de CTC, mas este agrupamento foi executado sem deixar claro os critérios usados.

Em condições tropicais, MATTIAZZO-PREZOTTO (1994), estudou critérios a serem adotados quando da adição de resíduos em solos ácidos, baseando- 
se na quantidade máxima permissivel de metais $(\mathrm{Cu}, \mathrm{Cd}, \mathrm{Ni}$ e $\mathrm{Zn})$. Verificou, entretanto, que o parâmetro de solo mais importante para avaliar o seu potencial para receber residuos que contenham metais pesados, é o conteúdo de argila e de óxidos de ferro e de alumínio, ao invés da CTC e do índice $\mathrm{pH}$. Os parâmetros químicos do solo sugeridos pela autora para selecionar o solo de clima tropical apto a receber residuos que contenham metais pesados, são muito diferentes dos preconizados por LOGAN \& CHANEY (1983), colocando em dúvida a possibilidade de transferência, para as condições tropicais, das recomendações estabelecidas para solos de clima temperado.

Para aplicação de residuos em solos ácidos em clima tropical, MATTIAZZO-PREZOTTO (1994), verificou que o pH deve ser no mínimo de 5,3. A capacidade de retenção dos metais nos solos estudados foi função do conteúdo de argila e dos teores totais de óxidos de $\mathrm{Fe}$ e $\mathrm{Al}$, e ainda o teor de carbono, não tendo nenhuma interferência direta da CTC. Os problemas com metais pesados em solos adubados com Le são minimizados quando o residuo aplicado contém baixa concentração daqueles, quando o solo possuir elevados teores de fósforo, de matéria orgânica, de cálcio e de CTC, e quando o $\mathrm{pH}$ do solo estiver próximo da neutralidade. A planta a ser cultivada deveria ser de espécie e variedade tolerantes aos metais pesados (WALKER, 1975; KIRKHAM, 1977 e MILLER et al., 1979). 
Tabela 3 - Conteúdos de metais pesados e quantidades adicionadas por 100 tha de Le (matéria seca) e o teor total máximo aceitável no solo (COTTENIE, 1981).

\begin{tabular}{|c|c|c|c|c|}
\hline Elemento & $\begin{array}{c}\text { Conteúdo no } \\
\text { Le }\end{array}$ & $\begin{array}{l}\text { Quantidade } \\
\text { aplicada do } \\
\text { elemento }\end{array}$ & $\begin{array}{c}\text { Teor no solo } \\
\text { após a } \\
\text { aplicação }\end{array}$ & $\begin{array}{l}\text { Teor total máximo } \\
\text { aceitável no solo }\end{array}$ \\
\hline & $\mathrm{mg} \cdot \mathrm{kg}^{-1}$ & kg/ha & & $\mathrm{ng} \cdot \mathrm{kg}^{-1}$ \\
\hline $\mathrm{Hg}$ & 5 & 0,5 & 0,17 & $5^{(1)}$ \\
\hline Co & 25 & 2,5 & 0,83 & $50^{(1)}$ \\
\hline Cd & 50 & 5 & 1,66 & $3^{(1)}-10^{(2)}$ \\
\hline $\mathrm{Ni}$ & 200 & 20 & 6,66 & $50^{(1)}-200^{(2)}$ \\
\hline $\mathrm{Cu}$ & 1.000 & 100 & 33,33 & $500^{(1)}-1000^{(2)}$ \\
\hline $\mathrm{Cr}$ & 1.000 & 100 & 33,33 & $100^{(1,2)}$ \\
\hline $\mathrm{Pb}$ & 1.000 & 100 & 33,33 & $200^{(1)}-700^{(2)}$ \\
\hline $\mathrm{Mn}$ & 1.000 & 100 & 33,33 & $400^{(1)}$ \\
\hline $\mathrm{Zn}$ & 3.000 & 300 & 100 & $300^{(1)}-2000^{(2)}$ \\
\hline $\mathrm{Fe}$ & 18.000 & 1.800 & 600 & - \\
\hline
\end{tabular}

FONTE: ${ }^{(1)}$ de COTTENIE(1981) $\mathrm{e}^{(2)}$ de PEPIN \& COLEMAN (1984) 


\subsection{Metais Pesados no Sistema Solo-Planta-Animal}

\subsubsection{Crômio}

A contaminação do ambiente pelo $\mathrm{Cr}$ origina-se da galvanoplastia, de ligas metálicas, de esgoto industrial e de produtos químicos. Na natureza, o elemento está associado, em jazidas na África do Sul e Rodésia, à presença de $\mathrm{Mg}^{+2}, \mathrm{Fe}^{+2}, \mathrm{Al}^{+3}$ e $\mathrm{Fe}^{+3}$, e ainda ao oxigênio (ADRIANO, 1986). O teor de $\mathrm{Cr}$ em solos, como observado para os demais metais, é determinado pelo material de origem dos mesmos. O teor nos solos encontra-se na faixa de 5 a $1000 \mathrm{mg} \cdot \mathrm{kg}^{-1}$, notando-se que os teores mais elevados ocorreram naqueles derivados de rochas ígneas e serpentina (ALLOWAY, 1990). O teor médio nos solos é da ordem de $50 \mathrm{mg} . \mathrm{kg}^{-1}$. McGRATH \& SMITH (1990), encontraram que $25 \%$ do $\mathrm{Cr}$ total dos solos de clima temperado eram solúveis em $\mathrm{HCl} 0,1 \mathrm{~N}$.

O teor de Cr solúvel em solos paulistas foi determinado por MATTIAZOPREZOTTO (1994), extraindo-o por três soluções extratoras $\left(0,05 \mathrm{M}\right.$ de $\mathrm{Ca}\left(\mathrm{NO}_{3}\right)_{2}$; $0,1 \mathrm{M}$ de $\mathrm{HCl}$ e $0,05 \mathrm{M}$ de DTPA $\mathrm{pH} 7,3$ ), obtendo respectivamente: traços a 0,25; 0,63 a 4,72 e 0,02 a $7,63 \mathrm{mg} \cdot \mathrm{kg}^{-1}$.

Segundo KABATA-PENDIAS \& PENDIAS (1984), o comportamento do $\mathrm{Cr}$ no solo é condicionado pelo $\mathrm{pH}$ e pelos teores de matéria orgânica e de fosfatos de $\mathrm{Fe}, \mathrm{Mn}$ e Al. A forma e a concentração de $\mathrm{Cr}$ que está solúvel no solo são muito importantes, pois dependendo delstes parametros poderá ou não ocorrer fitotóxidez (BERTON, 1992). $0 \mathrm{Cr}^{6+}$ é muito tóxico, o que não ocorre com $\circ \mathrm{Cr}^{3+}$, que é praticamente insolúvel. Em soluções nutritivas, MORTVEDT \& GIORDANO (1975) 
observaram que o nivel fitotóxico varia entre 5 e 500 unidades, quando a forma presente é $\mathrm{Cr}^{6+}$.

Os teores médios de $\mathrm{Cr}$ encontrados em Le estão acima de $70 \mathrm{mg} \cdot \mathrm{kg}^{-1}$ (BETTIOL et al., 1983), e presume-se que o mesmo neste material não deve oferecer risco, em virtude da reduzida possibilidade do $\mathrm{Cr}^{6+}$ estar associado à matéria orgânica (BERTON, 1992).

Para os vegetais o $\mathrm{Cr}$ não é elemento essencial, sendo seu conteúdo nestes menor que $1 \mathrm{mg} \cdot \mathrm{kg}^{-1}$, raramente atingindo a $5 \mathrm{mg} \cdot \mathrm{kg}^{-1}$. Os vegetais têm mecanismo que não permite que o $\mathrm{Cr}$ se concentre em nível tóxico, pois as plantas o imobilizam nas raizes, não sofrendo translocação para a parte aérea e, quando isto ocorre, vai para os vacúolos (LOGAN \& CHANEY, 1983). Devido ao excesso de $\mathrm{Cr}$ no solo pode-se induzir deficiência de Fe (GROVE \& ELLIS, 1980). Tal interação negativa ocorre pela proximidade de tamanhos dos seus raios iônicos, o que possibilita ao $\mathrm{Cr}$ substituir o $\mathrm{Fe}$ em processos geoquímicos e biológicos.

O Cr é essencial ao homem e aos animais, pois é componente ativo na formação de elastina (UNDERWOOD, 1977).

\subsubsection{Cádmio}

O teor de Cd na crosta terrestre está ao redor de 0,15 a $0,20 \mathrm{mg} \cdot \mathrm{kg}^{-1} . \mathrm{A}$ quantidade de cádmio total nos solos varia, em função das suas rochas de origem, na faixa de 0,3 a $11 \mathrm{mg} \cdot \mathrm{kg}^{-1}$, com valor médio de $7,5 \mathrm{mg} \cdot \mathrm{kg}^{-1}$ nas rochas sedimentares; de 0,1 a $1,0 \mathrm{mg} \cdot \mathrm{kg}^{-1}$ nas rochas metamórficas e de 0,1 a $0,3 \mathrm{mg} \cdot \mathrm{kg}^{-1}$ 
nas rochas ígneas. Áreas vizinhas às fundiçōes podem apresentar conteúdos de cádmio na camada superficial do solo entre 0,20 e $350 \mathrm{mg}^{-\mathrm{kg}^{-1}}$ (ADRIANO, 1986; ALLOWAY, 1990; FERGUSON, 1990).

O Cd é adicionado ao solo em pequenas proporções através de impurezas dos adubos fosfatados (MALAVOLTA, 1980; ADRIANO, 1986). Em comparação aos fosfatos, o Le tem teor de Cd maior (o mesmo acontecendo com outros metais pesados), que é de 10 a $1500 \mathrm{mg} \cdot \mathrm{kg}^{-1}$ (IPT/CETESB, 1983). As refinarias de zinco $(\mathrm{Zn})$ constituem a principal fonte de poluição do solo com Cd. Óleos lubrificantes e pneus de veículos também contribuem com Cd para o ambiente. Dessa forma, excesso de Cd em solos pode ocorrer ao longo de estradas por contaminação ocasionada pelo tráfego de veículos. No solo, o Cd encontram-se adsorvido e precipitados nas suas partículas e permanece parte dele na forma trocável, sendo pequena a mobilidade deste metal pesado (BERTON, 1992); já o seu teor decresce com a profundidade (ADRIANO, 1986), pois o Cd esta intimamente associado a distribuição da matéria orgânica no perfil do solo. O comportamento do Cd segue praticamente os mesmos padrões do Zn (KIEKENS \& COTTENIE, 1985), ligando-se aos radicais hidroxila e fosfato e precipitando-se; pode ainda ligar-se a radicais orgânicos ou substituir o $\mathrm{Fe}^{3+}$ no solo e nos processos biológicos. Segundo SLAVEK \& PICKERING (1988), a mobilidade no solo e na água de cátions metálicos, como $\mathrm{Cd}^{+2}, \mathrm{Zn}^{+2}, \mathrm{Cu}^{+2}$ e $\mathrm{Pb}^{+2}$, pode ser modificada pela interação com os óxidos de alumínio e ferro e com a matéria orgânica.

Em solos brasileiros o teor de $\mathrm{Cd}$ total se situa entre valores menores que 0,1 até $0,4 \mathrm{mg}^{\mathrm{kg}}{ }^{-1}$ (FERGUSON, 1990). Os solos paulistas apresentam valores 
de Cd solúvel extraídos pelas soluções, de 0,05M de $\mathrm{Ca}\left(\mathrm{NO}_{3}\right)_{2} ; 0,1 \mathrm{M}$ de $\mathrm{HCl}$; e $0,05 \mathrm{M}$ de DTPA pH 7,3, na faixa de 0,01 a 0,05 ; de 0,03 a 0,17 e 0,02 a $0,16 \mathrm{mg} \cdot \mathrm{kg}^{-1}$, respectivamente (MATTIAZZO-PREZOTTO, 1994).

SANCHEZ-MARTINS \& SANCHEZ-CAMAZANOL (1993), verificaram que as formas de $\mathrm{Cd}$ presentes em solos ácidos têm seus comportamentos influenciados pelo conteúdo de argila e ṕela CTC desses solos.

A calagem do solo reduz o teor de $\mathrm{Cd}$ biodisponivel, devido ao aumento da concentração de cálcio no solo e à elevação do pH, acentuando ainda mais a redução quando este for acima de 6,0 (PAGE et al., 1983). A influência do pH do solo é marcante na absorção de Cd pelas plantas. Isto porque, se o pH é de 6,8 , apenas $50 \%$ do metal em relação ao teor original permanecem solúveis, e se há um pH de 10,9, cerca de $98 \%$ do elemento precipitam-se (OLIVEIRA et al., 1992). Variando o $\mathrm{pH}$ de 4,5 a 7,4 de solos contaminados por $\mathrm{Cd}$ originado de fundições dito inorgânico ou de Le na forma de Cd orgânico, foram encontrados teores de 2,86 a $371 \mathrm{mg} \cdot \mathrm{kg}^{-1}$, nas formas de $\mathrm{CdCl}^{+}, \mathrm{CdOH}^{+} \mathrm{e}$ o ion $\mathrm{Cd}^{+}$livre (TILLS \& ALLOWAY, 1983).

Os teores de Cd nas plantas tidos como normais variam entre $0, \mathrm{I}$ a $\mathrm{I}$ mg.kg-1 (FERGUSON, 1990). As plantas variam muito em sua habilidade em absorver, acumular e tolerar $\mathrm{Cd}$. Entre as culturas, o $\mathrm{Cd}$ pode tornar-se um problema sério na lavoura de fumo, pois ocorre um acúmulo mais acentuado de Cd na folha por unidade desse metal no solo do que em qualquer outra espécie vegetal (BERTON, 1982; PAGE et al., 1983). Esta planta apresentou teores foliares de Cd de 1 a $44 \mathrm{mg} . \mathrm{kg}^{-1}$ (base seca), quando cresceu em solos onde o teor total do elemento era de $1 \mathrm{mg} \cdot \mathrm{kg}^{-1}$ 
(LOGAN \& CHANEY, 1983). A habilidade das plantas de fumo em concentrarem Cd no tecido é explicada pela eficiência do seu sistema radicular em absorve-lo (MENCH \& MARTIN, 1991).

CLARK et al. (198I), observaram que o Cd, quando em excesso na parte aérea e nas raízes, provocava uma redução na matéria seca, variando de 10 a 100 partes, em relação à testemunha. FERGUSON (1990) relatou que o alface, o espinafre, o aipo e o repolho acumularam $\mathrm{Cd}$ nas suas partes aéreas em teores que variaram de 175 a 354 mg. $\mathrm{kg}^{-1}$, quando cresciam em solo cujo teor de $\mathrm{Cd}$ total era de $640 \mathrm{mg} \cdot \mathrm{kg}^{-1}$. JURADO (1989) verificou que o arroz reduziu o seu crescimento e as quantidades absorvidas de N, P, K, Ca, Mg e Zn quando a concentração de Cd na solução nutritiva era superior a $0,05 \mathrm{mg} / \mathrm{dm}^{3}$, enquanto no feijão, com o emprego de niveis acima de $0,005 \mathrm{mg} / \mathrm{dm}^{3}$, observou-se redução no crescimento e aumento nos conteúdos de Fe, Cu e Mn.

A absorção do Cd pela planta pode ocorrer nas raizes e nas folhas (KABATA-PENDIAS \& PENDIAS, 1986). Não é comum encontrar plantas com sintomas de fitotoxidez causados pelo $\mathrm{Cd}$. Isto se deve, provavelmente, pelo fato de acumular-se nas raízes e a sua absorção ser inibida ou diminuída pelo antagonismo ao $\mathrm{Ca}^{2+}, \mathrm{Mn}^{2+}$ e $\mathrm{H}_{2} \mathrm{PO}_{4}^{-}$, de modo semelhante ao que ocorre com o $\mathrm{Zn}^{2+}$ (PAGE et al., 1983). Nem todo o Cd absorvido é translocado para a parte aérea das plantas. Segundo BERTON (1992), somente 10 a $50 \%$ da quantidade do metal absorvido é translocado para a parte aérea, dependendo da espécie vegetal e mesmo do cultivar. 
A principal causa da fitotoxidez pelo Cd parece ser devida à sua combinação com grupos tiólicos $\left(\mathrm{SH}^{-}\right.$e $\left.\mathrm{S}^{-2}\right)$ das enzimas e das proteínas citoplasmáticas, formando complexos metal-proteina de alta estabilidade, o que provoca desarranjos no metabolismo pela inativação das primeiras (FERGUSON, 1990). Efeitos tóxicos para o homem têm sido observados quando o teor nas plantas consumidas como alimento excedem a $3 \mathrm{mg} \cdot \mathrm{kg}^{-1}$.

\subsubsection{Chumbo}

Nos solos agrícolas o conteúdo de $\mathrm{Pb}$ total varia de 2 a $200 \mathrm{mg} \cdot \mathrm{kg}^{-1}$, concentrando-se nas camadas superficiais (SWAINE, 1955). Uma pequena fração deste é solúvel em ácido acético $0,5 \mathrm{~N}$ ou em acetato de amônio neutro. Em solos onde há jazidas já foram encontradas concentrações de 3000 a $5000 \mathrm{mg} \cdot \mathrm{kg}^{-1}$, causando toxidez às plantas e aos animais que as ingerem (MALAVOLTA, 1980). Os teores mais comumente encontrados nos solos estão entre 15 a 25 mg.kg ${ }^{-1}$ (AUBERT \& PINTA, 1977).

Em solos muito ácidos, assim como aqueles com reação próxima da neutralidade, $\mathrm{O} \mathrm{Pb}$ pode formar sulfato, preferencialmente na medida que $\mathrm{oH}$ se eleva, e em solos alcalinos, este tenderia a associar-se aos carbonatos praticamente insolúveis (LAMBAIS, 1988). Todas essas formas são muito pouco solúveis, e acentua-se ainda mais a insolubilidade à medida que se eleva $\mathrm{o} \mathrm{pH}$ do meio (OVERCASH \& PAL, 1979). Portanto, a disponibilidade do $\mathrm{Pb}$ do solo às plantas é baixa devido à forte retenção pelo complexo coloidal e às reações de insolubilização 
desse elemento, diminuindo-se ainda mais com adição de calcário e fosfato (BERTON, 1992).

Quando se adicionam residuos orgânicos ao solo, o chumbo e o cobre tendem predominantemente a associar-se com os constituintes orgânicos (KIEKENS \& COTTENIE, 1985). Isto explica porque o $\mathrm{Pb}$ acumula-se nos horizontes húmicos e argilosos dos solos (AUBERT \& PINTA, 1977).

A absorção de $\mathrm{Pb}^{2+}$ pelas plantas sofre a competição do $\mathrm{Ca}^{2+}$, dificultando a absorção radicular daquele, fazendo com que a sua incorporação no vegetal seja baixissima (AUBERT \& PINTA, 1977; BERTON, 1992; entre outros autores). As plantas toleram maiores concentraçòes nas raizes até atingir à fitotoxidez, em relação à parte aérea. Por exemplo, quando o teor de $\mathrm{Pb}$ nas raizes foi de $78 \mathrm{mg} \cdot \mathrm{kg}^{-1}$, provocou uma redução de $63 \%$ na produção destas em comparação à testemunha; quando o teor de $\mathrm{Pb}$ na parte aérea foi de $23,2 \mathrm{mg} \cdot \mathrm{kg}^{-1}$, ocasionou uma produção desprezivel, expressa em matéria seca (CLARK et al., 198I).

Os teores encontrados nas sementes são muito pequenos, na ordem de $0,5 \mathrm{mg} \cdot \mathrm{kg}^{-1}$ de MS. Ressalte-se que o $\mathrm{Pb}$ não é translocado para os grãos não havendo, portanto, possibilidade de causar efeitos deletérios ao homem e a outros animais que têm este produto na sua dieta alimentar na forma de farinhas, óleos ou mesmo "in natura" (BERTON, 1992). 


\subsubsection{Níquel}

Geoquimicamente, o Ni encontra-se quase sempre associado ao $\mathrm{Co}, \mathrm{Cu}$ e $\mathrm{Zn}$, comumente substituindo os íons $\mathrm{Mg}$ e $\mathrm{Fe}$ em muitos minerais, como por exemplo a serpentina. O Ni e Co nas rochas estão geralmente associados, e nos solos estão relacionados ao ín sulfato. No estado puro, dada a sua grande resistência à corrosão, o $\mathrm{Ni}$ é empregado em indústrias de galvanoplastia como revestimento eletrolítico, servindo para proteger ligas de $\mathrm{Fe}$ ou $\mathrm{Cu}$ e, melhorar as propriedades térmicas e mecânicas de numerosas ligas (POMBO et al., 1989). Portanto, efluentes destas indústrias podem conter elevado conteúdo de $\mathrm{Ni}$, dando como conseqüência Le com alto teor deste metal. UREN (1992), acredita que o Ni esteja presente predominantemente em formas associadas a compostos orgânicos.

Os teores de $\mathrm{Ni}$ total nos solos, encontrados na literatura, variam na faixa de 3 a 700 mg.kg-1 (ADRIANO, 1986; MITCHELL, 1945; AUBERT \& PINTA, 1977), mas em média é muito baixo, em torno $100 \mathrm{mg} \cdot \mathrm{kg}^{-1}$ (AUBERT \& PINTA, 1977; MALAVOLTA, 1976 e 1980). Esta amplitude é causada por vários fatores, inclusive o material de origem, sendo que teores menores que o limite inferior são encontrados em solos calcários. MELLO et al. (1988) resumiram valores médios nos solos originários de serpentinas em vários países, os quais variaram de 2600 a 7000 mg.kg-1. Estes teores no solo, segundo MALAVOLTA (1980), provocarão com freqüência a toxidez em plantas e em animais que delas se alimentarem. Os solos do Estado de São Paulo, derivados de rochas básicas, apresentam teores de 52 e $126 \mathrm{mg} / \mathrm{dm}^{3}$ e são mais altos que os solos derivados de sedimentos recentes arenosos ( $\left.<20 \mathrm{mg} \cdot \mathrm{kg}^{-1}\right)$. 
$\mathrm{Na}$ literatura existem vários trabalhos que apresentam valores de $\mathrm{Ni}$ solúvel. Por exemplo, TAYLOR et al. (1992) extrairam o Ni pela solução de Mehlich 1 (HCl $0,05 \mathrm{Ne} \mathrm{H}_{2} \mathrm{SO}_{4} 0,025 \mathrm{~N}$ ) e encontraram teores variando de 2,3 e 4,2 mg.kg ${ }^{-1}$, em solos de áreas degradadas pela mineração. O Ni no solo é praticamente imóvel por estar associado à matéria orgânica, pois o metal forma quelatos com as substâncias húmicas (ADRIANO, 1986; AUBERT \& PINTA, 1977),.

Em quatro solos paulistas, segundo MATTIAZZO-PREZOTTO (1994), os teores de $\mathrm{Ni}$ extraídos por três extratores $\left(0,05 \mathrm{M}\right.$ de $\mathrm{Ca}\left(\mathrm{NO}_{3}\right)_{2} ; 0,1 \mathrm{M}$ de $\mathrm{HCl}$ e $0,05 \mathrm{M}$ de DTPA pH 7,3), foram nas faixas de 0,03 a 0,$36 ; 0,19$ a 0,57 e 0,07 a $0,47 \mathrm{mg} \cdot \mathrm{kg}^{-1}$, respectivamente. Para ROVERS et al. (1983), o teor de Ni em solos, extraídos pelo DTPA, variaram na faixa de $<0,5$ a $1,4 \mathrm{mg} \cdot \mathrm{kg}^{-1}$. VALADARES et al. (1983) demonstraram que existe uma alta correlação entre os teores de Ni-solúveis em DTPA e as doses de Ni adicionadas ao solo, na forma de Le.

O Ni é usualmente absonvido na forma catiônica como bivalente da solução do solo ou da solução nutritiva. A absorção do elemento, de acordo com MISHRA \& KAR (1974) e MALAVOLTA (1976), é relativamente fácil quando fomecido na forma iônica, mas toma-se bastante diminuída quando o mesmo está na forma de quelato, pois este é muito estável, tomando-o menos disponivel às plantas.

A fitotoxidez pode ocorrer quando se cultivam vegetais em solos contaminados por $\mathrm{Ni}$, devido a adição de resíduos industriais (como os de galvanoplastia ricos no elemento), ou em solos próximos a jazidas de minerais que contem Ni. Por exemplo, HUNTER \& VERGANO (1952a), SOANE \& SAUNDER (1959) e HALSTEAD et al. 
(1969), verificaram toxidez de $\mathrm{Ni}$ em aveia, milho, alfafa e fumo, cultivados em solos encontrados próximos a rochas contendo serpentinas.

A essencialidade do $\mathrm{Ni}^{++}$na nutrição de plantas foi estabelecida em 1975, quando se verificou que era componente da enzima urease extraida de plantas de feijão e soja (McGRATH \& SMITH, 1990; UREN, 1992).

HALSTEAD et al. (1969) verificaram que não há possibilidade de se determinar com precisão um teor crítico único para o Ni em plantas de aveia e de alfafa, acima do qual ocorreria a toxidez, pois este variava com a espécie. Os autores verificaram também que o teor no solo que seria tóxico às plantas variou em função do seu teor de argila. Encontraram que na folha e grãos de aveia teores acima de 60 e 28 mg. $\mathrm{kg}^{-1}$ de Ni, assim como em folhas de alfafa com mais de $44 \mathrm{mg} \cdot \mathrm{kg}^{-1}$ de $\mathrm{Ni}$, causariam toxidez. Em geral, ALLAWAY (1968), LOGAN \& CHANEY (1983) e ADRIANO (1986), afirmam que o $\mathrm{Ni}$ é tóxico às plantas em concentrações no tecido superiores a $50 \mathrm{mg} \cdot \mathrm{kg}^{-1}$ e a toxidez está associada indiretamente à deficiência de Co (McGRATH \& SMITH, 1990 e LOGAN \& CHANEY, 1983), de Ca e Zn no feijão e de Ca, Mg, Mn e Zn no arroz (ÁNTON, 1990).

Os sintomas de toxidez de $\mathrm{Ni}$ em gramíneas consistem em clorose ao longo das nervuras, a folha inteira pode ficar esbranquiçada e, em casos extremos, há necrose nas margens (MALAVOLTA, 1980). Nas dicotiledôneas aparece uma necrose intemerval das folhas semelhante à deficiência de Mn, a partir de observação em plantas de tomates e de batatas (HEWITT, 1953). ANTÓN (1990) verificou que o sintoma típico de toxidez de Ni é semelhante ao de carência de Fe em culturas de feijão, indicando o deslocamento do Fe nas reações bioquímicas que participa pelo $\mathrm{Ni}$. 
A absorção da maioria dos elementos é diminuida pelo excesso de $\mathrm{Ni}, \mathrm{o}$ que pode ser explicado por ser este causador de danos às raizes (MALAVOLTA, 1980), pois já foi observado que em tomateiro o elemento danifica o sistema radicular (KNIGHT \& CROOKE, 1956), diminuindo a subsequente absorção e translocação dos elementos essenciais. MISHIRA \& KAR (1974), constataram que excessos de Ni podem causar distúrbios na fase mitótica da divisão celular, nas pontas das raizes. Outro aspecto de fitotoxidez de Ni, discutido por vários autores e, obsenvado também por ANTÓN (1990), é a redução na quantidade de clorofila no tecido foliar do arroz e do feijão, devido a uma desorganização das ultraestruturas celulares nas folhas, o que prejudica o seu sistema fotossintético.

Não aparecem na literatura descrição dos niveis tóxicos de Ni no homem, porque há pequena absorção do elemento pelo organismo, mesmo quando altas quantidades são fomecidas na dieta alimentar (UNDERWOOD, 1977).

\subsubsection{Selênio}

O Se é encontrado em pequenas quantidades na crosta terrestre (100 mg. $\mathrm{kg}^{-1}$ ) e seu teor médio na litosfera é de $0,09 \mathrm{mg} \cdot \mathrm{kg}^{-1}$ (SWAINE, 1955). O Se pode ser encontrado no solo sob três formas que se tomam disponiveis por lentos processos de hidrólise: selênio livre, selênio pirítico e selênio férrico básico (MELLO et al., 1988). Pode estar ainda associado ao material orgânico do solo. Teores muito elevados são encontrados em certos solos humíferos (AUBERT \& PINTA, 1977). 
Segundo MALAVOLTA (1980), as rochas ígneas apresentam teores de Se mais baixos que as rochas sedimentares, por isso há maior freqüência de fitotoxidez causada por Se em solos derivados deste material de origem. Solos com teores de Se que podem causar fitotoxidez tem sido encontrados nos Estados Unidos, Havaí, Porto Rico, Canadá, China e Cuba (MELLO et al., 1988).

No solo, o conteúdo de Se é baixo $\left(0,2 \mathrm{mg} \cdot \mathrm{kg}^{-1}\right)$, segundo MALAVOLTA (1980), sendo sua distribuição no perfil muito variável e dependente de diversos fatores, tais como: idade do solo, textura, composição química, CTC, material de origem e precipitação pluviométrica (MELLO et al., 1988). De um modo genérico, os teores de Se total e solúvel em água, são menores nos horizontes superficiais do que nas camadas mais profundas. Solos ricos em Se são encontrados quase sempre em regiōes áridas, e neles aparecem as plantas acumuladoras de Se ou seleniferas. Em solos com pH $<$ 7,0, o elemento está presente na forma de selenito, podendo estar fixado pelos minerais contendo Fe e formar complexos com a matéria orgânica, dependendo do $\mathrm{pH}$, do grau de aeração e da atividade microbiológica do solo, o que irá definir o estado de oxidação do Se (MALAVOLTA,1980).

As plantas absonem Se na forma de selenatos e possivelmente de alguns compostos orgânicos, os quais aparecem comumente em solos alcalinos e bem arejados. Existem plantas que chegam a acumular $1500 \mathrm{mg} \cdot \mathrm{kg}^{-1}$ de selênio nas regiões de crescimento e nas sementes (MALAVOLTA, 1980). O Se, juntamente com os ions molibdato e nitrato, podem ser absorvidos pelas plantas as quais, se ingeridas como forragem, podem causar efeitos deletérios aos animais (FERGUSON ,1990; BERTON, 1992 e MALAVOLTA, 1994). 
As propriedades químicas do Se são muito parecidas com as do $\mathrm{S}$, sendo que os dois elementos competem pelo mesmo sítio de absorção. O Se é incorporado aos aminoácidos no lugar do enxofre formando outros compostos, como selenometionina e selenocisteina, por exemplo (BERTON, 1992; MALAVOLTA,1980; KABATA-PENDIAS \& PENDIAS, 1986 e AUBERT \& PINTA, 1977). A literatura relata que na cultura da salsinha, o Se pode substituir o S na ferredoxina, sendo necessário para a atividade da redutase do nitrato (KABATA-PENDIAS \& PENDIAS, 1986; MALAVOLTA,1980).

Em condições de baixas concentrações, o Se tem mostrado um pequeno efeito estimulante no crescimento das plantas. As formas de Se presentes no Le e estercos são de baixa solubilidade no solo e por isso raramente são absorvidas pelas plantas até atingir um nível tóxico, mesmo quando o cultivo se dá em solos onde altas doses do mesmo são aplicadas (BERTON, 1992).

\subsection{Respostas de Culturas à Adição de Le}

\subsubsection{Culturas alimenticias}

No Brasil, culturas como soja, arroz e milho já foram empregadas como indicadores da possibilidade de uso do Le como fertilizante, (BETTIOL \& CARVALHO, 1982).

BETTIOL et al. (1982), estudando os efeitos da utilização do Le como fertilizante para o arroz cultivado em casa de vegetação, verificaram a não ocorrência de diferenças significativas entre as produções obtidas com a adubação mineral e o resíduo. 
Verificaram também que qualquer das doses empregadas de Le foram superiores à testemunha absoluta (sem adição do resíduo), em produção de material vegetal.

GUSHI et al. (1982) e GUIMARÃES et al. (1982), comparando o efeito de doses crescentes de Le, suplementadas ou não com nitrogênio e potássio, verificaram haver respostas positivas na produtividade da cultura do feijão.

As produções de matéria seca de plantas de milho, arroz e soja obtido com a dose de 9 tha de Le, conduzidos em pequenos vasos em cas d/de vegetação, não diferiram significativamente das obtidas com a fertilização mineral (BETTIOL, 1982a). Já BERTON et al. (1989) e CUNNINGHAM et al. (1975), verificaram efeitos positivos na cultura do milho quando empregaram doses de Le mais elevadas (40 a 80 t/ha), e o mesmo fato se repetiu ainda para a cultura de sorgo granifero, onde foram aplicadas as doses de 30 e 60 tha de Le (DIAS, 1994).

KEEFER et al. (1979) obtiveram, em comparação à testemunha, um pequeno ganho de produção de milho doce fomecendo $P$, na forma de Le, nas doses de 20 a 60 t/ha. Entretanto, verificaram que o Le provocou deficiências de nitrogênio e de potássio nas plantas, não ocorrendo problemas com metais pesados.

ROS et al. (1993) verificaram que o Le aplicado em doses de 80 e 160 t/ha, pode elevar a produtividade em matéria seca, sendo que o efeito pode se dar de dois modos distintos: o efeito imediato sobre a produção de milheto e o efeito residual na produção de grãos de aveia, em associação com ervilhaca. Os autores atribuíram os aumentos de produtividade citados ao fomecimento de nutrientes, devido à mineralização pela população microbiana do solo da fração orgânica mais facilmente oxidável do Le. KELLING et al. (1977) e CARVALHO \& BARRAL(198I) observaram que o Le proporciona 
um melhor aproveitamento de nutrientes pelas plantas, visto que os mesmos estão na forma orgânica e são liberados gradativamente e podem melhor atender às exigências nutricionais no decorrer do ciclo biológico. Entretanto, VLAWS \& WLLIANS(1971) recomendam que não se deve dispensar inicialmente uma complementação com fertilizantes minerais, para compensar esta lenta mineralização.

A literatura traz vários trabalhos nos quais o Le é usado como fonte de $P$ para culturas alimentícias (BOARETTO, 1986 e 1992; CABRE et al. , 1990; AYUSO et al., 1992; CARVALHO \& BARRAL, 1981 e SABEY et al., 1977). BOARETTO et al. (1992), verificaram que a aplicação do Le teve uma tendência de aumento de produtividade de grãos de feijão, mas constataram uma baixa disponibilidade do $\mathrm{P}$ do Le em comparação ao P do superfosfato triplo. Nos grãos de feijão não obsenaram aumento do teor de Cd provocado pela adubação com Le, mas houve tendência de aumento do seu teor de $\mathrm{Ni}$. Em outro experimento, BOARETTO (1986) verificou que a disponibilidade do P do Le para soja e amoz foi de 37 a 82 e de 21 a $52 \%$, respectivamente, tendo o superfosfato simples como padrão, igual a $100 \%$. Todavia, a complementação do Le em 10 a $20 \%$ com adubo fosfatado mostrou-se superior ao próprio adubo químico aplicado, individualmente. Os benefícios do Le como fonte de P melhorando a sua disponibilidade no solo, refletindo em maior produtividade, podem ser explicados pela produção de agentes complexantes que facilitam a mobilização de fosfatos que normalmente acham-se combinados com ferro e aluminio do solo, devido à decomposição do Le (CARVALHO \& BARRAL, I98I).

DIAS (1994) observou que o Le proporcionou aumento na produção de matéria seca do sorgo granífero, comparado com a fertilização mineral. O Le sofrendo mineralização no solo fomeceu nutrientes $(\mathrm{N}, \mathrm{K}, \mathrm{Ca}$ e $\mathrm{S})$ para as plantas. BERTON et al. 
(1989) constataram que o Le é fomecedor de N, P, Ca, Mg e Zn para a cultura do milho, enquanto que os dados de CUNNINGHAM et al. (1975) indicaram maior absorçāo de N, P e K pela planta, adubados com Le, em comparação à testemunha. De acordo com MILLeR et al. (1979), 10 a 17,5 t/ha de Le atendem as necessidades nutricionais da cultura do milho. Todavia , salientou-se na pesquisa de GOTO(1983), que o Le fomeceu $\mathrm{N}, \mathrm{P}, \mathrm{Ca}, \mathrm{Mg}$ e S, que se acumularam na parte aérea e bulbo da cebola, mas não houve aumento na produção de biomassa. DUDAS \& PAWLUK (1975) observaram que a dose de 80 a 160 t/ha de Le incorporado ao solo, em condições de casa de vegetação, ocasionou desequilíbrio fisiológico na cultura de alface, reduzindo o crescimento inicial e ċausando clorose e crestamento na borda das folhas, e o sistema radicular se desenvolveu menos que na testemunha.

LOGAN \& MATTIAZZO-PREZOTTO (1992), verificaram que a biodisponibilidade de metais ( $\mathrm{Fe}, \mathrm{Cu}, \mathrm{Zn}$ e $\mathrm{Mn}$ ) é maior no solo tratado com mistura de resíduo de fomos da indústria de cimento (CKD) + Le, e que $30 \%$ do $\mathrm{N}$ total e $50 \%$ do $\mathrm{P}$ total adicionados na forma da citada mistura foram absorvidos por planta forrageira, e não houve qualquer fitotoxidez pelo aumento nos metais acumulados no vegetal.

O Le sem os cuidados de natureza sanitária teria seu uso agronômico limitado , pois se empregado na adubação de culturas para consumo "in natura" de hortaliças e frutas pelo homem, poderia oferecer risco à saúde, além de possibilitar a entrada de metais pesados na cadeia alimentar. Devido ao risco de atuar como vetor na transmissão de doenças à população, ALMY et al. (1977) recomendam empregar o Le como fertilizante em cereais e forrageiras, podendo-se acrescentar a esta lista a cana-deaçúcar e as florestas. 


\subsubsection{Cana-de-açúcar}

A sustentabilidade da produção da cultura de cana-de-açúcar só pode ser atingida quando os nutrientes no sistema têm balanço nulo ou positivo. Portanto, é essencial conhecer-se as perdas de nutrientes mais importantes no agrossistema. Dentre as possiveis causas de saida de nutrientes do solo, merecem destaque as quantidades exportadas pelos colmos. Tais quantidades, expressas em $\mathrm{g}^{-\mathrm{t}^{-1}} \mathrm{de}$ colmos, encontradas na literatura, foram de: 740 a 1100 de N, de 27 a 62 de $P$, de 820 a 3000 de K, de 89 a 213 de Ca, de 109 a 220 de Mg, 116 a 359 de S, de 0,9 a 2,1 de Zn, de 0,5 a 0,9 de Cu, de 19 a 36 de Fe, de 8 a 21 de Mn e de 9 a 35 de Al (PRIMAVESI et al., 1992 e ORLANDO F, 1983).

Os nutrientes exportados pelos colmos, podem ser compensados pela adição de resíduos orgânicos, adubação verde, entre outras técnicas de cultivo que maximizam a atividade biológica e mantêm a fertilidade e a produtividade do solo. Existem diversos residuos passiveis de uso agronômico na cultura de cana-de-açúcar, sendo o Le um deles.

Para avaliar os efeitos advindos da aplicação do Le ao solo, é necessário ter-se técnicas capazes de medir as alterações que ocorrem no solo e na planta: Para o primeiro caso, emprega-se usualmente a análise química das terras, que é de custo baixo (ORLANDO Fo, 1983). Já para o segundo caso, tem-se duas opções viáveis em se tratando de cana-de-açúcar, que são as análises químicas das folhas (RAlJ, 1991) ou as do caldo (BITTENCOURT et al., 1992). A análise dos macronutrientes no caldo para avaliar o estado nutricional da cultura de cana-de-açúcar foi proposta por BITTENCOURT 
et al. (1992): justificando que a mesma permite aproveitar a estrutura laboratorial já existente e empregada na determinação do teor de sacarose, no sistema de pagamento de cana (SPCTS), e porque é a metodologia analítica mais simples e rápida, pois dispensa a digestão da matéria vegetal. O método tem como hipótese de que é necessário ter um teor mínimo dos elementos no caldo para que as produtividades agricola e industrial sejam otimizadas. Assim, se o caldo não apresentar teores mínimos desejados de nutrientes é porque houve, durante o desenvolvimento da canade-açúcar, deficiências de nutrientes. No Estado de São Paulo a diagnose foliar e a análise de macronutrientes ( $\mathrm{N}, \mathrm{P}, \mathrm{K}, \mathrm{Ca}$ e $\mathrm{Mg}$ ) no caldo têm sido pouco usadas na cultura de cana-de-açúcar, talvez devido ao fato dos resultados serem pouco consistentes.

A seguir, são relatados os poucos trabalhos encontrados na literatura sobre o uso de Le como fertilizante na cultura da cana-de-açúcar.

MARQUES (1990) avaliou o comportamento tecnológico e composição em N, P e K do caldo de cana-de-açúcar adubada com doses crescentes de Le, aplicado na cana-planta e na cana-soca, comparativamente com a testemunha e a fertilização quimica NPK. O autor verificou que a aplicação de 4 a $8 \mathrm{t}$ /ha de Le na cana-planta, não teve efeito na concentração de $\mathbf{N}$ total no caldo e, aumentando as doses para 16 e 32 tha, houve redução nos teores desse nutriente no caldo em toda a safra. Este fato pode estar relacionado com o atraso da maturação dos colmos de cana ocorrida com a aplicação das maiores dosagens; pois de acordo com ALeXANDER (1973) o N poderia atrasar a maturação da cana-de-açúcar. Provavelmente, a necessidade de $\mathrm{N}$ na fase inicial de crescimento como nutriente que se relaciona à síntese protéica na planta, pode ter sido suprida nas primeiras doses de Le. 
O efeito "residual" do Le (aplicado no plantio da cana-planta), quanto ao fomecimento de $\mathrm{N}$ pelo citado resíduo à cana-soca foi pequeno, indicando que o fomecimento de N, restringiu-se à cana-planta. Este aspecto pode ser comprovado, pois quando reaplicarão Le ao solo, proporcionou aumentos de concentrações de $\mathbf{N}$ no caldo da cana-soca, em relação ao tratamento testemunha.

A ausência de efeito, ou mesmo a pequena redução no teor de $\mathbf{N}$ do caldo obtido na cana-planta, devido a adubação com Le poderia ser esperada, tendo em vista os resultados encontrados na literatura (ORLANDO $\mathrm{F}^{\circ}, 1983$ ). Verifica-se que a resposta à adubação nitrogenada em cana-de-açúcar em geral é baixa, principalmente no primeiro cultivo, em solos argilosos (ORLANDO F \& ZAMBELLO JR, 1980).

Um aspecto que deve ser lembrado é que a interpretação de resultados de $\mathrm{N}$-solúvel no caldo é muito difícil, pois os mesmos praticamente não foram influenciados pelos fertilizantes nitrogenados aplicados na lavoura e não estavam associados aos parâmetros de solo, como afirma BEAUCLAIR (1994).

O fósforo tem importância para a cana-de-açúcar, manifestada no desenvolvimento das raizes, na intensidade de perfilhamento e no crescimento do colmo (HUMBERT, 1968 e ALEXANDER, 1973). Na fase industrial, o teor de $\mathrm{P}$ no caldo está relacionado com a sua clarificação, para propiciar a obtenção do açúcar branco ( CESAR et al., 1987; SERRA, 1973) e é necessário na nutrição das leveduras, que fazem a fermentação do mosto para a produção do álcool etílico (AMORIM, 1985).

No Estado de São Paulo, com uma boa freqüência a cana-planta tem respondido, com aumento da produtividade à adubação fosfatada, como indicam os resultados de MALAVOLTA et al. (1963); FREIRE et al. (1968) e SERRA (1973). 
O fósforo, apesar de sua baixa exportação pelos colmos, tem necessidade de ser sempre aplicado na adubação (ORLANDO F, 1983), pois é fortemente adsorvido e precipitado no solo (MELLO et al., 1988). A concentração de $P$ nos colmos é crescente inicialmente, com uma queda do quarto ao oitavo mês, estabilizando-se a partir desta idade (HAAG et al., 1980).

O Le aplicado na dose de 32 t/ha em cultivo de cana-planta, propiciou um aumento substancial do fósforo extraído do solo com a resina, até os $\mathbf{2 3 0}$ dias após o plantio da cana, chegando a atingir a classe de teores de fertilidade média a alta (MELO \& MARQUES, 1992). No caldo de cana-de-açúcar, MARQUES (1990) analisou o $\mathrm{P}_{2} \mathrm{O}_{5}$, constatando um teor de fosfato solúvel significativamente maior do que o seu teor na testemunha do ensaio, embora tais teores tenham ficado aquém do teor ideal para a adequada clarificação para a produção do açúcar branco, conforme estabelecido em HONIG (1969). MARQUES (1990) verificou ainda que o maior acúmulo de $P$ no caldo foi obtido pela aplicação de 8 t/ha de Le. Segundo BEAUCLAIR (1994), o P acumulado no caldo da cana-planta sofre interferência dos teores de $\mathrm{K}$ e de Mg presentes neste.

O K atua em vários processos bioquímicos do metabolismo de carboidratos, de modo direto na fotossintese e na respiração, refletindo no ritmo de crescimento e na maturação. A participação do elemento no metabolismo de carboidratos refere-se principalmente no tocante aos processos de assimilação de $\mathrm{CO}_{2}$ e nitrogênio pela planta, favorecendo a formação de proteínas e a translocação e o amazenamento da sacarose no colmo (ALEXANDER, 1973). Entretanto, quando há excesso de potássio no solo, ocorre desequilíbrio fisiológico na planta, o que tem sido constatado em áreas onde se aplicam doses excessivas de vinhaça. Há então, como conseqüência, redução de pol 
da cana (GLORIA \& MAGRO, 1967; SILVA, 1982), aumento do teor de cinza do caldo (ORLANDO FILHO, 1978) e acúmulo acentuado de compostos orgânicos no ciclo de Calvin , como o amido (CESAR et al., 1978) e o ácido aconítico (CASANOVAS \& ARMAS, 1983; GUTIERREZ et al., 1988). BEAUCLAIR (1994) verificou que há correlação significativa entre o teor de $\mathrm{K}$ no caldo e as quantidades de pol e de ATR por tonelada de cana.

O Le não é um eficiente fomecedor de potássio à cana-de-açúcar, como se observa nos resultados de MARQUES (1990). O autor obteve aumento na concentração de $\mathrm{K}_{2} \mathrm{O}$ do caldo decorrente mais da aplicação de potássio mineral, do que pela aplicação do citado elemento na forma de Le. BEAUCLAIR (1994) verificou que o aumento da pol e do ATR da cana foi explicado pelas relações entre os teores de $\mathrm{K}$ e de $\mathrm{Ca}+\mathrm{Mg}$ no caldo.

Do ponto de vista tecnológico, MARQUES (1990) verificou que o emprego do Le não causou dificuldades adicionais para a cultura canavieira, pois não houve efeito do Le na pureza do caldo, embora tenha havido pequenas diminuições no valor do Brix e da pol da cana. Quanto à produtividade da cana-planta, não houve efeito do Le, mesmo se cultivada em solo com teores baixos de P e Ca e médio de K e ainda, elevada acidez. A provável explicação para o limitado desempenho do Le como fertilizante para a cultura de cana-de-açúcar, verificado por MARQUES (1990), pode ser devido à cultivar empregada (CB41-76), para a qual sabe que, embora tendo boa produtividade em biomassa, tem baixa a média riqueza em açúcar nos colmos, tem alta rusticidade e é pouco exigente em fertilidade do solo (CESAR \& SILVA, 1993). Portanto, a 
probabilidade desta cultivar responder em aumento de produtividade à melhora da fertilidade do solo, devido a aplicação de Le seria baixa.

Em outro experimento, MARQUES et al. (1994) avaliaram novamente a incorporação ao solo de 32 t/ha de Le em cultivo de cana-planta, mas já usando a cultivar SP70-6163. Observou-se então, em relação à fertilização mineral NPK de 413 kg/ha de 4-20-20, que a aplicação do Le resultou em redução de $6 \%$ no valor monetário da matéria prima (ágio). Notou-se ainda que a umidade da cana variou de forma diretamente proporcional às doses de Le, o mesmo ocorrendo com a relação açúcares redutores/cinzas no caldo, o que teoricamente favoreceria o seu maior esgotamento do melaço na fabricação do açúcar branco.

Verifica-se portanto, nos poucos resultados disponiveis na literatura onde se relata o emprego de Le na cultura canavieira, que o enfoque centrou-se nos aspectos agrotecnológicos, não havendo referência aos seus efeitos na fertilidade do solo e na nutrição da planta. 


\section{MATERIAL E MÉTODOS}

\subsection{Características Gerais do Local , do Le e do Cultivar de Cana-de- açúcar}

\subsubsection{Localização}

O experimento foi levado a efeito em área comercial na Fazenda Santa Helena, pertencente à Usina Costa Pinto S/A, situadas no municipio de Piracicaba, Estado de São Paulo, cujas coordenadas geográficas médias são: $22^{\circ} 42^{\prime}$ de latitude sul; $42^{\circ} 25^{\prime}$, de longitude oeste; $580 \mathrm{~m}$ de altitude.

\subsubsection{Clima}

A região de Piracicaba-SP apresenta clima característico do tipo Cwa (segundo classificação de Koeppen) tropical, úmido, com inverno seco (junho-julhoagosto), verão quente e úmido. A umidade relativa do ar apresenta média anual de $74 \%$, tendo insolação real e potencial médias mensais de 201,9 e 365,1 horas, respectivamente. A temperatura média do ar durante o verão é de $24,0^{\circ}$ e, durante o inverno é de $17,2^{\circ} \mathrm{C}$, apresentando uma média anual de $21,1^{\circ} \mathrm{C}$. 


\subsubsection{Características de Fertilidade do Solo e a Recomendação de} Fertilizantes.

O experimento foi instalado na primeira semana de março de 1993, em solo do grande grupo Podzólico Vermelho Amarelo, abrupto a moderado, textura arenosa/média, unidade Serrinha (Arenic Abruptic Paleudult).

A análise química de amostras compostas retiradas antes da instalação do ensaio nas profundidades de $0-20 \mathrm{~cm}$ e de $20-50 \mathrm{~cm}$, revelou o que se segue :

\begin{tabular}{|c|c|c|c|c|c|c|c|c|c|c|}
\hline Prof & M.O. & $\mathrm{pH}$ & $\mathrm{Ca}^{2+}$ & $\mathrm{Mg}^{2+}$ & $\mathrm{K}^{+}$ & $\mathrm{H}+\mathrm{Al}$ & SB & $T$ & $\mathbf{v}$ & P.res \\
\hline $\mathrm{cm}$ & $\overline{\text { g. } . \mathrm{kg}^{-1}}$ & $\mathrm{CaCl}_{2}$ & \multicolumn{6}{|c|}{$\mathrm{mmol}_{\mathrm{d}} / \mathrm{dm}^{3}$ de terra } & $\%$ & $\mathrm{mg} / \mathrm{dm}^{3}$ \\
\hline $0-20$ & 13,5 & 4,3 & $\overline{5,2}$ & 1,8 & $\overline{1,6}$ & 24,5 & $\overline{8,6}$ & 33,1 & 26 & $\overline{4,5}$ \\
\hline $20-50$ & 7,0 & 4,4 & 6,8 & 2,0 & 0,8 & 20,0 & 9,6 & 29,6 & 32 & 3,0 \\
\hline
\end{tabular}

\begin{tabular}{ccccccccc}
\hline Prof & $\mathrm{Fe}_{2} \mathrm{O}_{5}$ & $\mathrm{Al}_{2} \mathrm{O}_{5}$ & $\mathrm{Cd}$ & $\mathrm{Cr}$ & $\mathrm{Cu}$ & $\mathrm{Mn}$ & $\mathrm{Ni}$ & $\mathrm{Pb}$ \\
\hline $\mathrm{cm}$ & $\%$ & $\%$ & \multicolumn{6}{c}{$\mathrm{mg} \cdot \mathrm{dm}^{-3}$} \\
\hline $0-20$ & 2,8 & 2,2 & 0,05 & 0,06 & 0,6 & 30 & 0,20 & 0,97 \\
$20-50$ & 2,0 & 1,9 & 0,02 & 0,01 & 0,4 & 32 & 0,08 & 0,75 \\
\hline
\end{tabular}

Em face dos resultados de fertilidade do solo, calculou-se a recomendação de adubação de 60-80-100 (kg/ha de $\left.\mathrm{N}-\mathrm{P}_{2} \mathrm{O}_{5}-\mathrm{K}_{2} \mathrm{O}\right)$ na cana-planta, usando-se como fertilizantes sulfato de amônio, superfosfato triplo e cloreto de potássio (RAIJ et al, 1985). Os fertilizantes químicos quando recomendado no tratamento foram aplicados no sulco de plantio, empregando todo o fósforo, 1/3 das 
doses de potássio e de nitrogênio. Os restantes do $\mathrm{N}$ e $\mathrm{K}$ foram parcelados em duas aplicações de cobertura, aos 30 e 45 dias após plantio (dap). O lodo de esgoto foi aplicado no fundo do sulco de plantio.

\subsubsection{Composição do Lodo de Esgoto}

O Le foi fornecido pela Estação de Recuperação da Qualidade da Água (ERQ) de Barueri-SP, integrante do Projeto SANEGRAM (SABESP).

Obteve-se por incineração em mufla, o C total, e determinou-se o teor de $\mathbf{N}$ total, após digestão sulfurica pelo método do semi-micro Kjeldahl (SARRUGE \& HAAG, 1974). Mediu-se a condutividade elétrica do material na forma de pasta. Para os demais elementos do lodo de esgoto procedeu-se a digestão, via úmida, com extração em água régia $\left(\mathrm{HCl}+\mathrm{HNO}_{3}: 1+3\right)$, potencializada pela ação das microondas do forno da CEM Corporation S/A, o qual seguiu a técnica de NIEUWENHUIZE et al.(1991).

A composição média deste na matéria seca foi: C $\left(71^{*}\right) ; N\left(22^{*}\right)$; $\mathrm{Al}\left(2,0^{\star}\right), \mathrm{P}\left(10^{*}\right) ; \mathrm{K}\left(1,5^{\star}\right) ; \mathrm{Ca}\left(11,5^{\star}\right) ; \mathrm{Mg}\left(3,5^{\star}\right) ; \mathrm{S}\left(10^{\star}\right) ; \mathrm{Fe}\left(50^{\star}\right)$, expressos em $\mathrm{g}\left(\mathrm{hg}_{\mathrm{g}}^{*}\right) ; \mathrm{B}\left(8,5^{\star \star}\right), \mathrm{Cu}\left(905^{\star \star}\right) ; \mathrm{Zn}\left(1800^{\star \star}\right) ; \mathrm{Mn}\left(505^{\star \star}\right) ; \mathrm{Cd}\left(25^{\star \star}\right) ; \mathrm{Cr}\left(645^{\star \star}\right) ; \mathrm{Ni}\left(445^{\star \star}\right)$; $\mathrm{Pb}\left(265^{\star \star}\right)$, sendo $\mathrm{mg} \cdot \mathrm{kg}^{-1}\left({ }^{\star \star}\right) ; \mathrm{pH}(10,2) ;$ C.E. $(5,82$ milisiemens/cm); água $=620$ g.kg-1 e relação $\mathrm{C} / \mathrm{N}$ de 3,24 .

A determinação dos elementos químicos foi efetuada por espectrometria de emissão atômica com plasma acoplado (Apêndice 2). 


\subsubsection{Cana-de-açúcar}

A variedade empregada foi a RB $72-454$, sendo a mesma fornecida pela Usina Costa Pinto S/A. Esta foi escolhida em face de sua baixa exigência em fertilidade do solo, ótima produtividade agroindustrial do meio para o final da safra (CESAR \& SILVA, 1993), além de encontrar-se em expansão de área em todas as regiões canavieiras do Estado de São Paulo.

\subsection{Delineamento Experimental}

O delineamento experimental foi em blocos ao acaso, com 15 tratamentos e três repetições, totalizando 45 parcelas.

A parcela foi constituida de 5 linhas de 12 metros de comprimento, espaçadas nas entrelinhas em 1,10 m (SILVA et al., 1993).

A área útil da parcela compreendeu as três linhas centrais com $10 \mathrm{~m}$ de comprimento, descontando-se a bordadura ( $1 \mathrm{~m}$, de cada lado) ou seja, uma área efetiva de amostragem de $34 \mathrm{~m}^{2}$.

\subsection{Tratamentos, Amostragens de Solo, de Perfilhos, Material Vegetal e Preparo de Amostras}

Os tratamentos testados foram: 


$\begin{array}{lll}\text { T01 - Testemunha. } & T_{06}-20 \text { tha de Le+NK } & T_{11}-N P K \\ \text { T02 - NP } & T_{07}^{\prime}-40 \text { t/ha de Le+NK } & T_{12}-20 \text { t/ha de Le+NPK } \\ \text { T03 - } 20 \text { t/ha de Le+NP. } & T_{08}-P K & T_{13}-40 \text { t/ha de Le+NPK } \\ \text { T04 - } 40 \text { t/ha de Le+NP. } & T_{09}-20 \text { t/ha de Le+PK } & T_{14}-20 \text { t/ha de Le } \\ \text { T05 - NK } & T_{10}-40 \text { t/ha de Le+PK } & T_{15}-40 \text { t/ha de Le }\end{array}$

O esquema que segue mostra as épocas de amostragem do solo e de materiais vegetais :

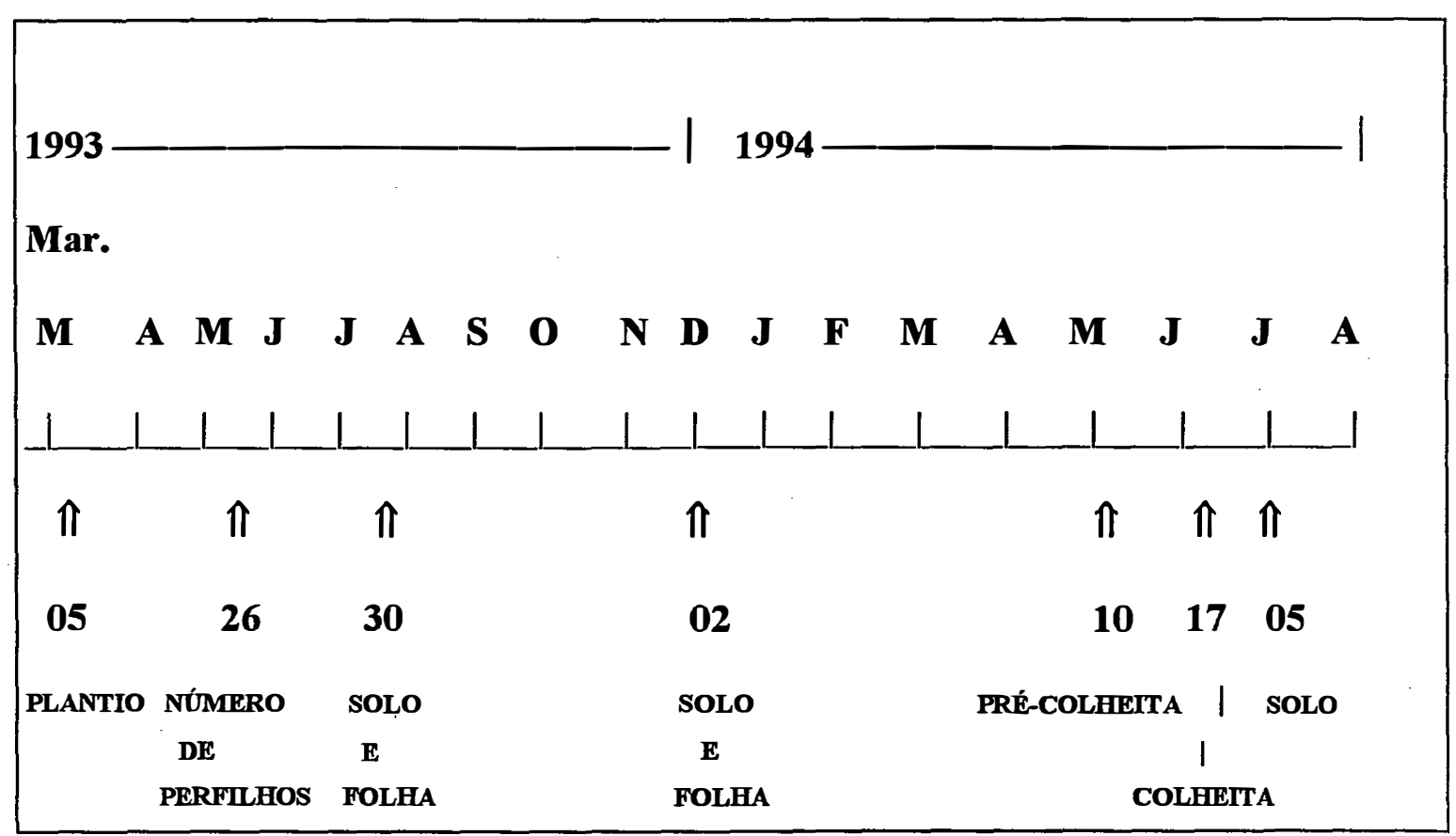

PERFILHAMENTO: a contagem do número de perfilhos por metro linear, por tratamento, foi realizada na área útil das parcelas em 82 dap (26/05/93), em toda a parcela. Em cada parcela, nas três linhas centrais, escolheu-se ao acaso em 12 
pontos, marcaram-se 2 metros de comprimento e procedeu-se a contagem e, a seguir, calculou-se o número médio de perfilhos.

SOLO : a amostragem foi realizada por tradagem a $0-20 \mathrm{~cm}$ de profundidade, em nove pontos, localizados na projeção do sulco de plantio da cultura, região que recebeu o lodo de esgoto. Estas foram então agrupadas e constituiu a amostra composta da parcela. Na seqüência, procedeu-se a secagem ao ar e à sombra destas amostras compostas, com posterior peneiragem em malha de $0,5 \mathrm{~mm} e$ acondicionamento em caixas de papelão. As amostragens, em número de três, ocorreram aos 146dias após o plantio (30/07/93), 272 dap (02/12/93) e 484 dap (05/07/94). Na última amostragem procedeu-se o acréscimo de uma outra amostra na profundidade de $20-50 \mathrm{~cm}$, visando avaliar o eventual movimento de nutrientes no perfil do solo.

FOLHAS: as amostragens foram feitas em duas épocas, ou seja aos 146 dap (30/07/93) e 272 dap (02/12/94), de acordo com ORLANDO FILHO \& CAMPOS (1975). A coleta da folha foi efetuada no período da manhã e constou da retirada, por parcela, de dezoito lâminas foliares da folha+1 na primeira época e +3 na última, de acordo com ordenação do "Método de Kuijpel" ( GALLO et al.,1962). Após a coleta das folhas de cada uma das três linhas centrais da parcela, procedeu-se ao corte e separação de cerca de $20 \mathrm{~cm}$ da região mediana. As amostras foram lavadas, colocadas para secagem em estufa com circulação forçada de ar, até peso constante $\left(65-70^{\circ} \mathrm{C}\right)$, moidas (40 mesh) e acondicionadas em frascos de vidro.

PRÉ-COLHEITA: para se determinar a exportação de nutrientes pela biomassa total (parte aérea), foram coletadas cinco canas, em seqüência, em cada uma das três 
linhas centrais da parcela. As amostras coletadas aos 431 dap (10/05/94), foram devidamente enfeixadas e etiquetadas. A produtividade de biomassa fresca dos colmos com ponta e folhas foi estimada pela contagem do número médio de canas por metro linear de cada tratamento, multiplicado pelo peso médio das canas. Tendo por base o valor de peso úmido de biomassa calculou-se a produção de matéria seca da parte aérea, que foi usada para chegar-se a exportação de nutriente.

COLHEITA FINAL: na amostragem final de colmos da parcela ocorrida aos 469 dap (17/06/94), adotou-se como critério a coleta de cinco canas em seqüência em cada uma das três linhas centrais da parcela. Tais amostras foram devidamente enfeixadas e etiquetadas. Os colmos foram despalhados pela ação do fogo e também despontados, isto é, houve a supressão da porção não madura do colmo. A maturação foi antecipada pela aplicação de Ethrell (2 L/ha), aos 411 dap (20/06/94). A colheita final da biomassa fresca dos colmos sem ponta do experimento foi realizada aos 469 dap (20/06/94),e então foram feitas as pesagens dos colmos da parcela (PBF), com auxilio de correntes presas à carregadora, com dinamômetro.

PREPARO DAS AMOSTRAS DE MASSA VEGETAL: as amostras de biomassa fresca da parte aérea e de colmos despontados, foram desagregadas em desintegrador tipo forrageira, e homogeneizadas em betoneira. Retirou-se então subamostras de 300 gramas, que foram levadas para secagem em estufa de circulação forçada de ar, até peso constante $\left(65-70^{\circ} \mathrm{C}\right)$, e determinou-se a umidade. Face à relação peso seco/peso fresco da sub-amostra, estimou-se a produção de biomassa seca dos colmos com ponta e folhas e colmos sem ponta . A matéria seca obtida foi 
passada em moinho tipo Wiley (40 mesh) e acondicionada em frascos, para posterior dosagem do conteúdo de nutrientes e metais pesados.

\subsection{Determinações Analíticas}

\subsubsection{Nas Características Agrotecnológicas}

Das amostras de canas já desintegradas retiraram-se sub-amostras de 500 g para a extração do caldo, através da prensa hidráulica (TANIMOTO, 1964). Obtiveram-se então o caldo extraído (CE) e o bagaço fibroso da prensa, que foram empregados nas determinações dos parâmetros tecnológicos. Com os resultados procederam-se os cálculos, conforme encontra-se em CESAR \& SILVA (1993).

a) Brix \% CE, determinado por refratometria a $20^{\circ} \mathrm{C} / 20^{\circ} \mathrm{C}$ (SCHNEIDER, 1979);

b) Pol \% CE, dosado pelo método de Schmitz sem diluição, segundo ICUMSA (SCHNEIDER, 1979);

c) Pureza aparente do CE, calculada pela relação entre a Pol \% CE/Brix \% CE x 100;

d) Peso úmido do bagaço fibroso da prensa (PBU), através da pesagem do resíduo fibroso, resultante da prensagem; 
e) Peso seco do bagaço fibroso da prensa (PBS), obtido através da pesagem do resíduo fibroso seco, até peso constante $\left(100-105^{\circ} \mathrm{C}\right)$, em estufa de circulação forçada de ar;

f) Açúcares Redutores \% CE (AR \% CE), expresso em glicose, dosados pelo método colorimétrico de Somogyi \& Nelson.

g) Cinzas \% CE, dosado pelo método do rafinômetro de Buse-Tödt-Gollnow (BROWNE \& ZERBAN, 1941);

h) $\mathrm{P}_{2} \mathrm{O}_{5}$, expresso em $\mathrm{mg} \cdot \mathrm{L}^{-1}$, determinado pelo método colorimétrico (DELGADO \& CESAR, 1984);

i) Açúcares Totais \% CE (AT \% CE), expressos em glicose e determinados pela fórmula:

$$
A T \% C E=\frac{P O L \% C E}{0,95}+A R \% C E
$$

Posteriormente, tendo como base os resultados anteriores, calcularam-se:

a) Fibra \% Cana (F), utilizando metodologia de TANIMOTO (1964) adaptada por STURION \& FERNANDES (1979), segundo a fórmula:

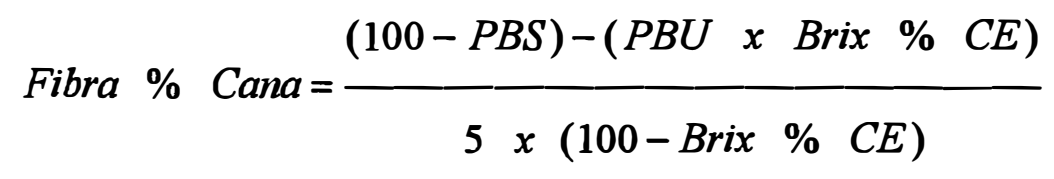


b) Pol da cana, segundo CESAR \& SILVA (1993), através da seguinte expressão:

$$
\text { Pol \% Cana }=\text { Pol \% CE } \times(0,9428-0,010469 \times \text { F }) \text {, }
$$

c) Brix da Cana, segundo CESAR \& SILVA (1993), através da seguinte expressão:

Brix \% Cana = Brix \% CE x(1,01083 - 0,,0124 x F ),

d) Açúcares Redutores \% Cana (AR \% cana), segundo a equação:

$$
A R \% \text { Cana }=\text { AR \% CE }(0,9428-0,010469 \times F)
$$

Açúcar Teórico Recuperável (ATR) nas condições normais de industrialização (FERNANDES, 1986), expresso em $\mathrm{kg} / \mathrm{t}$ de colmos frescos, cuja fórmula baseia-se em valores médios de perdas de eficiência na indústria para recuperar o açúcar produzido no campo. Ou seja, a pol ou a sacarose aparente passivel de cristalização por tonelada de cana, menos as perdas na lavagem, no bagaço, na torta e indeterminadas, resultando no açúcar que chega à seção de cozimento, o que permite avaliar os tratamentos agrícolas de modo global em um único valor. Empregou-se a fórmula da COPERSUCAR ( FERNANDES, 1986): 


$$
A T R=(10 X S-0,76 X F-6,9) \times \frac{5}{3}-\frac{200}{3 X(P j-1)}
$$

sendo:

$\mathrm{S}=$ pol da cana

F $=$ Fibra \% cana

$\mathrm{Pj}=$ Pureza do caldo

6,9 = soma de perdas de açúcar na lavagem, na torta de filtro e indeterminadas.

Para estimar-se a produtividade econômica dos tratamentos adotaramse como critérios de avaliação a Tpol/ha e a TAH, calculadas como se demonstra a seguir:

- A produtividade de sacarose (pol) por hectare (TPol/ha):

$$
T \text { pol / ha }=\frac{P B F \quad x \quad \text { Pol } \% \text { Cana }}{100}
$$

- A produtividade de ATR por hectare (TAH), em t.ha-1:

$$
T A H=\frac{P B F \times A T R}{1000}
$$




\subsubsection{Nutrientes e metais pesados nas amostras vegetais}

Para determinação do $\mathbf{N}$ total nas amostras de matérias secas e moidas das folhas, dos colmos + folhas e dos colmos despontados, empregou-se a digestão sulfúrica e dosagem pelo método do semi-micro Kjeldahl (SARRUGE \& HAAG, 1974).

Para a determinação dos outros nutrientes e metais pesados na matéria seca das folhas e o B em todos os tecidos vegetais, foi empregada a digestão por via seca (BATAGLIA et al., 1983b). Já para a determinação dos seus teores nas matérias secas dos tecidos dos colmos com e sem folhas, empregou-se a digestão nítricoperclórica (SARRUGE \& HAAG, 1974).

Nos extratos, para os demais nutrientes e metais pesados foram determinados por espectrômetro de emissão atômica por plasma com acoplamento indutivo Jobin Yvon-J45OP-simultâneo, sendo eles os seguintes elementos: $\mathrm{Ca}, \mathrm{Cd}$, $\mathrm{Cr}, \mathrm{Cu}, \mathrm{Fe}, \mathrm{K}, \mathrm{Mg}, \mathrm{Mn}, \mathrm{Ni}, \mathrm{P}, \mathrm{Pb}, \mathrm{S}, \mathrm{Se}$ e $\mathrm{Zn}$. Os limites de detecção do método usado nas análises dos multielementos no tecido vegetal foram de $0,5 \mathrm{mg} \cdot \mathrm{kg}^{-1}$ de MS para o Ca, Mg, S e P; de $3^{*}$ para o Al; de 1 a $2^{\star}$ para o $\mathrm{Zn}, \mathrm{Cu}$ e $\mathrm{Fe}$; de $0,2^{\star}$ para o $\mathrm{Mn}, \mathrm{Pb}, \mathrm{Cd}, \mathrm{Ni}, \mathrm{Cr}$ e Se, onde os valores foram expressos em $\mathrm{mg} \cdot \mathrm{kg}^{-1} \mathrm{de} \mathrm{MS}\left({ }^{*}\right)$.

\subsubsection{Análises Químicas do Solo}

Foram feitas as análises químicas de rotina pelo sistema IAC, obtendo: 
a) Matéria Orgânica ( RAIJ et al., 1987);

b) $\mathrm{pH}$ em solução de $\mathrm{CaCl}_{2}$ 0,01M (RAlJ et al., 1987);

c) Acidez potencial $(\mathrm{H}+\mathrm{Al})$, determinada potenciometricamente pela solução tampão SMP (RAIJ et al., 1987);

d) Fósforo, potássio, cálcio e magnésio extraídos pela resina trocadora de íons e determinados por espectrofotometria de absorção atômica (RAlJ, et al., 1987);

e) Enxofre- $\mathrm{SO}_{4}{ }^{2-}$, extraído com solução de $\mathrm{CaCl}_{2}\left(1,5 \mathrm{~g} \cdot \mathrm{kg}^{-1}\right)$ e determinado como $\mathrm{BaSO}_{4}$ por turbidimetria (WILLIANS \& STEINBERG, 1959);

f) Nitrogênio total, pelo método semi-micro Kjeldahl (SARRUGE \& HAAG, 1974);

g) Boro extraído em cloreto de bário em forno de microondas e determinado colorimetricamente com curcumina ( IAC, 1994);

h) Cobre, manganês, zinco, cromo, niquel, chumbo, ferro e cádmio, os quais foram extraídos pela solução DTPA pH 7,3 (LINDSAY \& NORVELL, 1978) e determinados por espectrometria de plasma de emissão atômica, nos mesmos comprimentos de onda citados para os materiais vegetais. 
i) Oxidos de ferro e de aluminio totais, pelo método do ataque sulfúrico (VETTORI,1969).

\subsection{Métodos Estatisticos}

O procedimento de montagem do experimento foi em blocos ao acaso, com três repetições e quinze tratamentos. Em fase inicial procedeu-se a Análise da Variância do ensaio, e o Contraste entre médias para os fatores doses de Le e complementação com fórmula química, pelo Teste de Tukey a $5 \%$ de probabilidade e, para as doses de Le utilizou-se modelo polinomial de $1^{\circ}$ e $2^{\circ}$ graus (GOMES, 1986).

Para melhor avaliar as componentes dos tratamentos promoveu-se a separação das causas de variação (doses de lodo e fórmulas químicas) e ainda o fator Época de Amostragem para o delineamento em blocos ao acaso, com parcelas sub-divididas no tempo para análise de folhas e de solo, através de contrastes ortogonais das médias e Análise de Variância (teste F).

A dose recomendada do lodo de esgoto com a possivel suplementação de nutrientes foi definida com a técnica de regressão polinomial de $2^{\circ}$ grau, onde $X=$ doses de Le, t/ha e $y=$ nutriente no solo, na planta ou parâmetros da biomassa fresca.

Para se aprofundarem os conhecimentos sobre os parâmetros do solo e da planta que causariam alterações nas produções de biomassas e na produtividade em açúcar, utilizou-se a seleção de índices edáficos e biológicos 
variáveis nos métodos de seleção de equações de regressão linear múltipla, adotando-se como procedimento o uso da técnica de todos os possíveis modelos pelo Cp de Mallöws(1975), que foram calculados em microcomputador PC-IBM 386, usando o Software SANEST, versão 3.0, e a teoria de base pormenorizada em MATTIOLLI (1983). 


\section{RESULTADOS E DISCUSSÃO}

\subsection{Condições Agrometeorológicas Durante o Experimento}

A precipitação média no período foi abaixo da necessidade da cultura, compreendendo de maio até outubro/94, ocorrendo deficiência hídrica (Apêndice 1). A falta de água e o uso de Ethrell, favoreceram a plenitude da maturação dos colmos da cultura de cana-de-açúcar, o que possibilitou antecipação da colheita do ensaio para junho.

\subsection{Lodo de Esgoto: Composição e Legislação.}

Pela composição média de macronutrientes do Le, constatou-se o baixo teor de K, em relação aos dados da literatura (item 3.1.4.). Quando se comparou o Le utilizado no ensaio com o resíduo dos Estados Unidos (PURVES, 1985), verificou-se que o primeiro possuía cerca da metade do $\mathrm{N}$ e do $\mathrm{P}$ contidos no segundo. No tocante à composição do Le em micronutrientes e metais pesados, como pode ser observado na Tabela 2 (no item 2.3.), constatou-se que o teor de $\mathrm{Ni}$ era pouco mais elevado do que o resíduo usado nos Estados Unidos, Reino Unido e Canadá (ADRIANO, 1986). Do ponto de vista da Legislação, ao comparar-se a 
composição do Le usado no ensaio com as especificações de uso e disposição agricola deste, verificou-se que o resíduo preenche as normas estabelecidas pela Agência Americana de Proteção ao Meio Ambiente no Registro Federal de 19/03/1993 (53 FR [32]: 9248-9415) na 40CFR parte 503 (ESTADOS UNIDOS, 1993). Observa-se, entretanto, que o teor de $\mathrm{Ni}$ do Le usado no ensaio encontrava-se muito próximo do limite máximo estabelecido pela Legislação citada, que é de $420 \mathrm{mg} \cdot \mathrm{kg}^{-1}$ de MS. Esta Legislação da Agência Americana citada é mais tolerante e ampliou os limites para diversos metais pesados, possibilitando assim que maior volume de Le seja empregado na agricultura. O valor mais elevado de Ni no Le usado no ensaio não implica necessariamente em teor extraído com DTPA mais alto no solo, pois o teor de $\mathrm{Ni}$ no solo depende diretamente da sua solubilidade neste, a qual é função de diversos fatores, como teores de matéria orgânica, argila, óxidos de $\mathrm{Fe} \mathrm{e} \mathrm{Al,} \mathrm{pH} \mathrm{,}$ entre outros (ADRIANO, 1986; KABATA-PENDIAS \& PENDIAS, 1986 e KIEKENS \& COTTENIE, 1985).

\subsection{Lodo de Esgoto e a Fertilidade do Solo}

$\mathrm{Na}$ caracterização inicial para fins de fertilidade do solo (PVa) onde foi instalado o ensaio, verificou-se que as camadas de $0-20$ e $20-50 \mathrm{~cm}$ de profundidade eram homogêneas e apresentavam CTC $=33 \mathrm{mmol}_{\mathrm{c} . \mathrm{dm}^{-3}}$ e os teores de matéria orgânica baixo, e de nutrientes, muito baixo (Ca, $\mathrm{Mg}, \mathrm{K}$ e P); $\mathrm{pH}$ em $\mathrm{CaCl}_{2}$ baixo, $\mathrm{H}+\mathrm{Al}$ elevada, SB e $\mathrm{V}$ baixas (RAlJ et al., 1985). O solo assim caracterizado 
indica que há possibilidade de resposta da cana-de-açúcar ao aumento da $\mathrm{V}$ e à aplicação do P e K.

Nas figuras 1 a 5 , encontram-se os resultados do comportamento dos parâmetros empregados para avaliação da fertilidade do solo, em três épocas distintas. Procederam-se os desdobramentos estatísticos (Apêndice 3) e os gráficos foram elaborados apenas para as variáveis de solo onde a adubação química complementar e a interação Le $\mathrm{x}$ adubação química foram significativas. Para as variáveis que não foram significativas para os fatores Fórmula quimica e a interação Le x Fórmula procedeu-se então ao uso de médias para as doses do resíduo aplicado no solo. Ocorreram efeitos significativos para a adição do Le $\left(F^{\star \star}\right)$, para a época $\left(F^{\star \star}\right)$ e para a interação Le $x$ época $\left(F^{\star \star}\right)$ para as seguintes variáveis de solo: $\mathrm{pH}$ em $\mathrm{CaCl}_{2}$ ; P; Ca; H+Al; SB e V; CTC, Zn; B; Cu; S e Mn.

Os coeficientes de variação do fator tratamento (resíduo A) dos indices de fertilidade do solo (Apêndice 3), foram: baixo (< 10 \%) para pH, médio (de 10 a 20 \%) para MO, $\mathrm{H}+\mathrm{Al}, \mathrm{CTC}, \mathrm{V}, \mathrm{B}, \mathrm{Fe}$ e $\mathrm{Mn}$ e alto (de 20 a $30 \%$ ) para P-resina, $\mathrm{K}^{+,} \mathrm{Ca}^{2+}$, $\mathrm{Mg}^{2+}, \mathrm{SB}, \mathrm{Cu}^{2+}, \mathrm{SO}_{4}{ }^{2-}$ e $\mathrm{Zn}^{2+}$, de acordo com critério de GOMES (1985). Os valores altos de coeficiente de variação para algumas das variáveis e para o fator época de amostragem de solo ( resíduo B), indicam que houve problema de amostragem, porque o Le foi aplicado no sulco de plantio, que tem $30 \mathrm{~cm}$ de profundidade em média, e que logo após, juntamente com o tolete com 15 a $20 \mathrm{~cm}$ de terra, mas com o passar do tempo, praticamente desaparece o sulco, devido receber mais terra diluindo os nutrientes do Le desigualmente. 


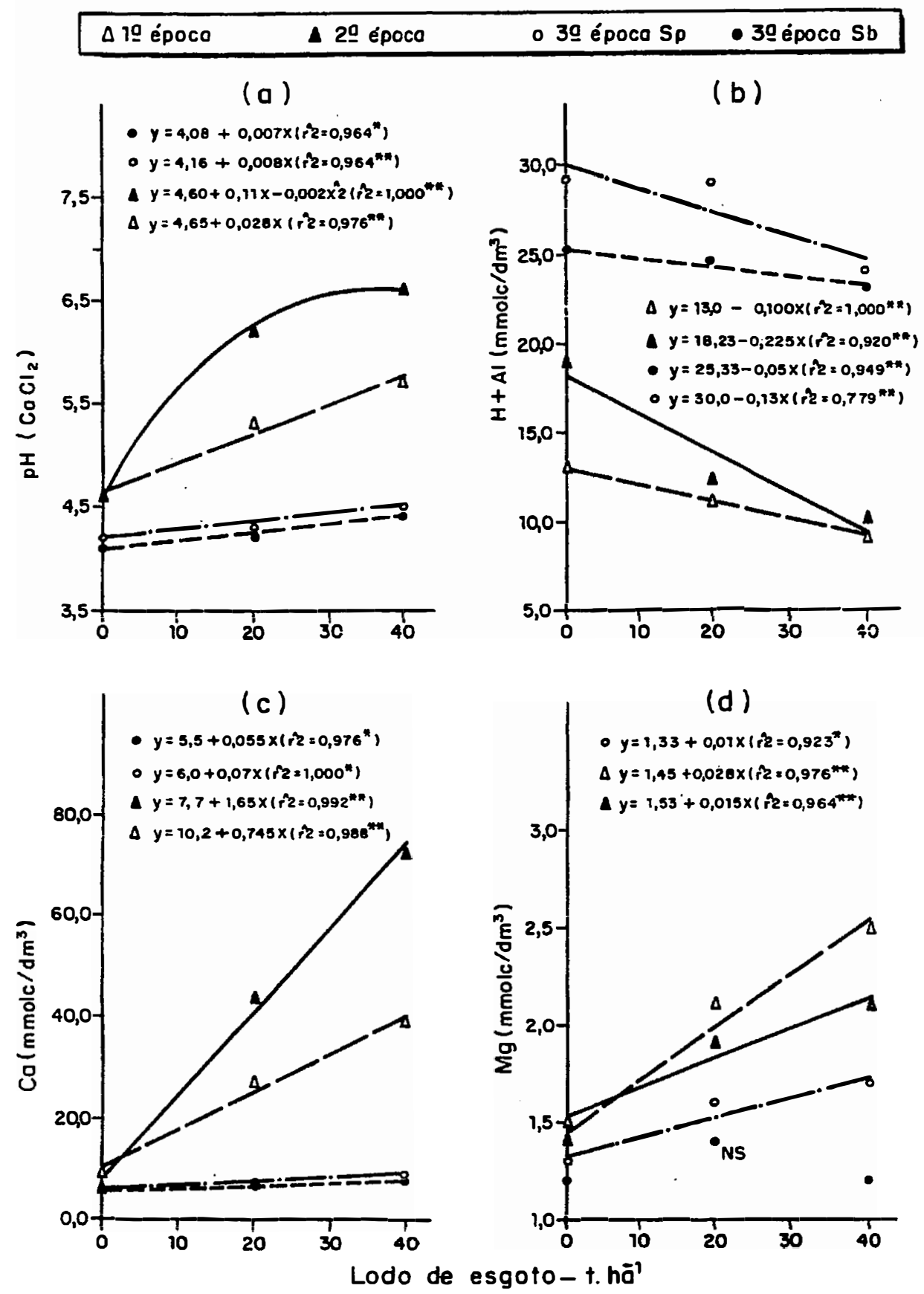

Figura 1 - Influência do oplicaçāo de doses de lodo de esgoto na acidez ativa $(a=p H)$ e potencial $(b=H+A l)$, teores de cálcio (c) e magnésio(d) no solo, oos 146, 272 e 484 dap.

* significativo a $5 \%$ de probabilidade, no teste $F$ * significativo a $1 \%$ de probabilidade, no teste $F$ NS não significativo, no teste $F$.

Sp-amostra de superficie, de 0 a $20 \mathrm{~cm}$ Sb-amostra de superfície, de 20 a $50 \mathrm{~cm}$ 

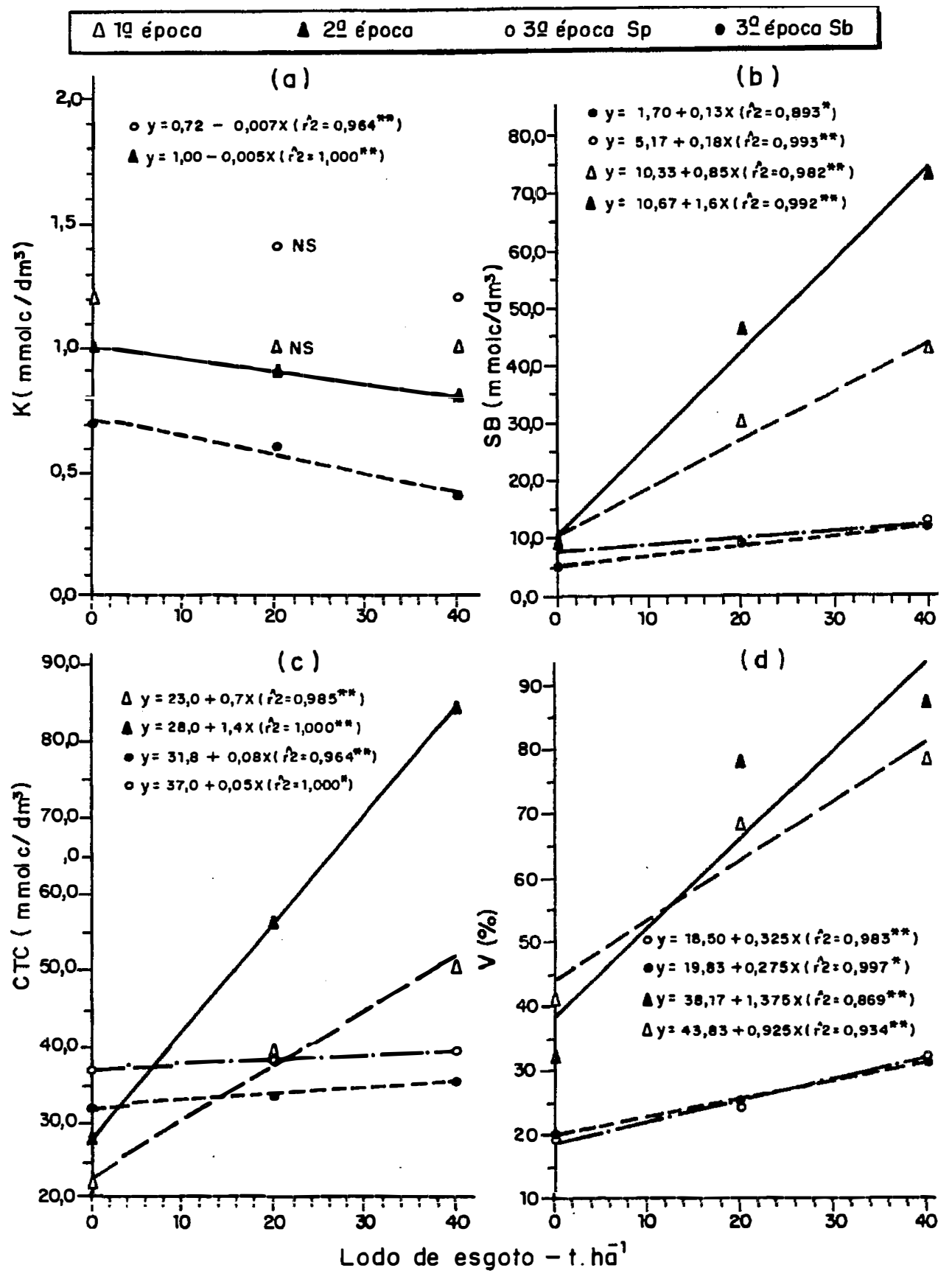

Figura 2-Influência da aplicaçāo de doses de lodo de esgoto nos teores de potássio (a), de bases(b), capacidade de troca cationica (c) e saturaçáo de bases (d) no solo, aos 146, 272 e 484 dap.

*-significativo a $5 \%$ de probabilidade, no teste $F$. ** - significotivo a $1 \%$ de probobilidade, no teste $F$. NS - nōo significotivo, no teste $F$. $S p$ - omostro de superfície, de 0 o $20 \mathrm{~cm}$ $\mathrm{Sb}$ - amostro de superfície, de 20 a $50 \mathrm{~cm}$ 


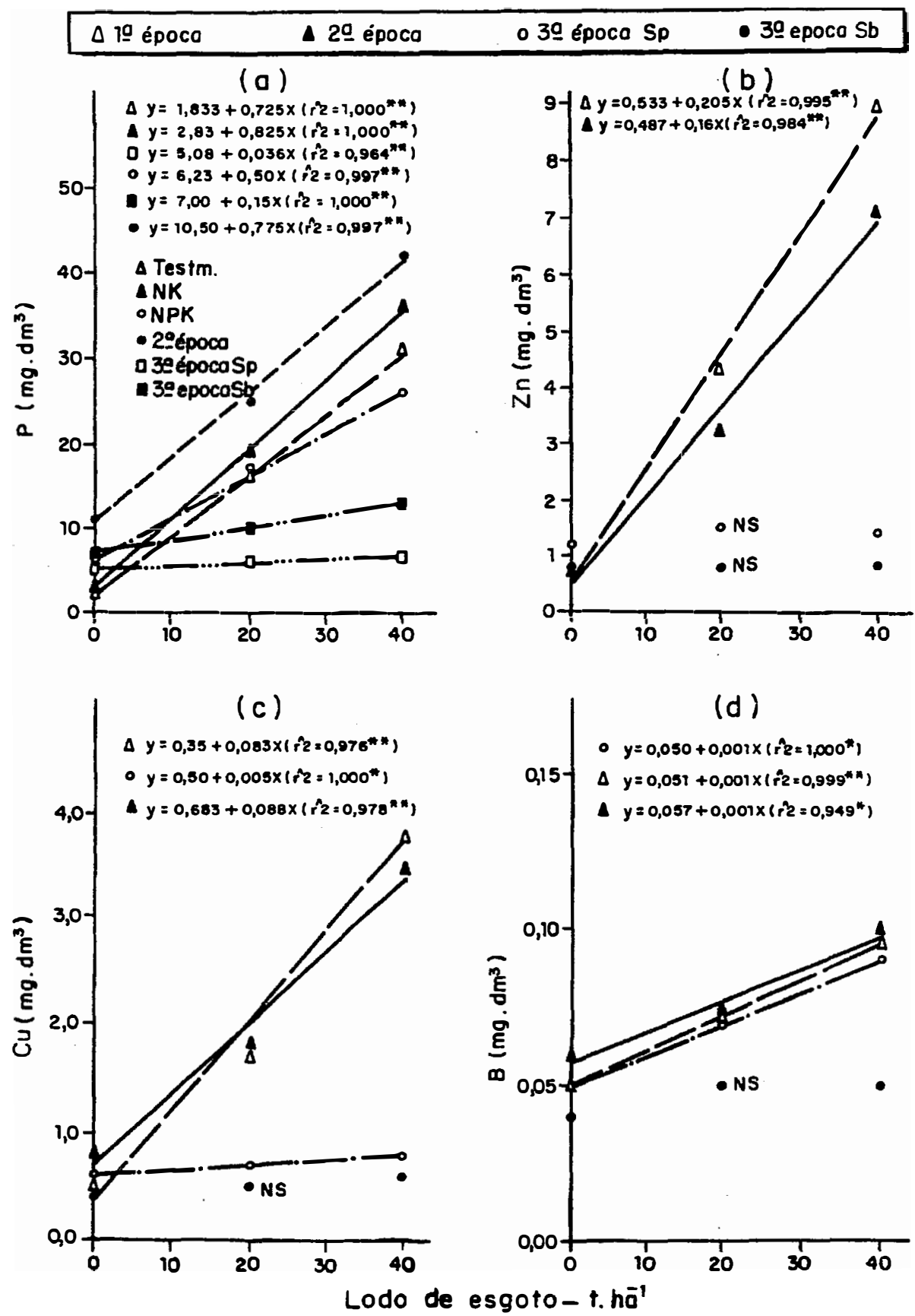

Figura 3-Influência da aplicacōo de doses de lodo de esgoto nos teores de fósforo (a), de zinco (b), de cobre (c), de boro (d) no solo, aos 146,272 e 484 dap.

*-significativo a $5 \%$ de probabilidade, no teste $F$ **-significativo a $1 \%$ de probabilidade, no teste $F$ NS-nōo significativo, no teste $F$

Sp-omostra de superfície de 0 o $20 \mathrm{~cm}$ Sb-amostra de superfície de 20 a $50 \mathrm{~cm}$ 

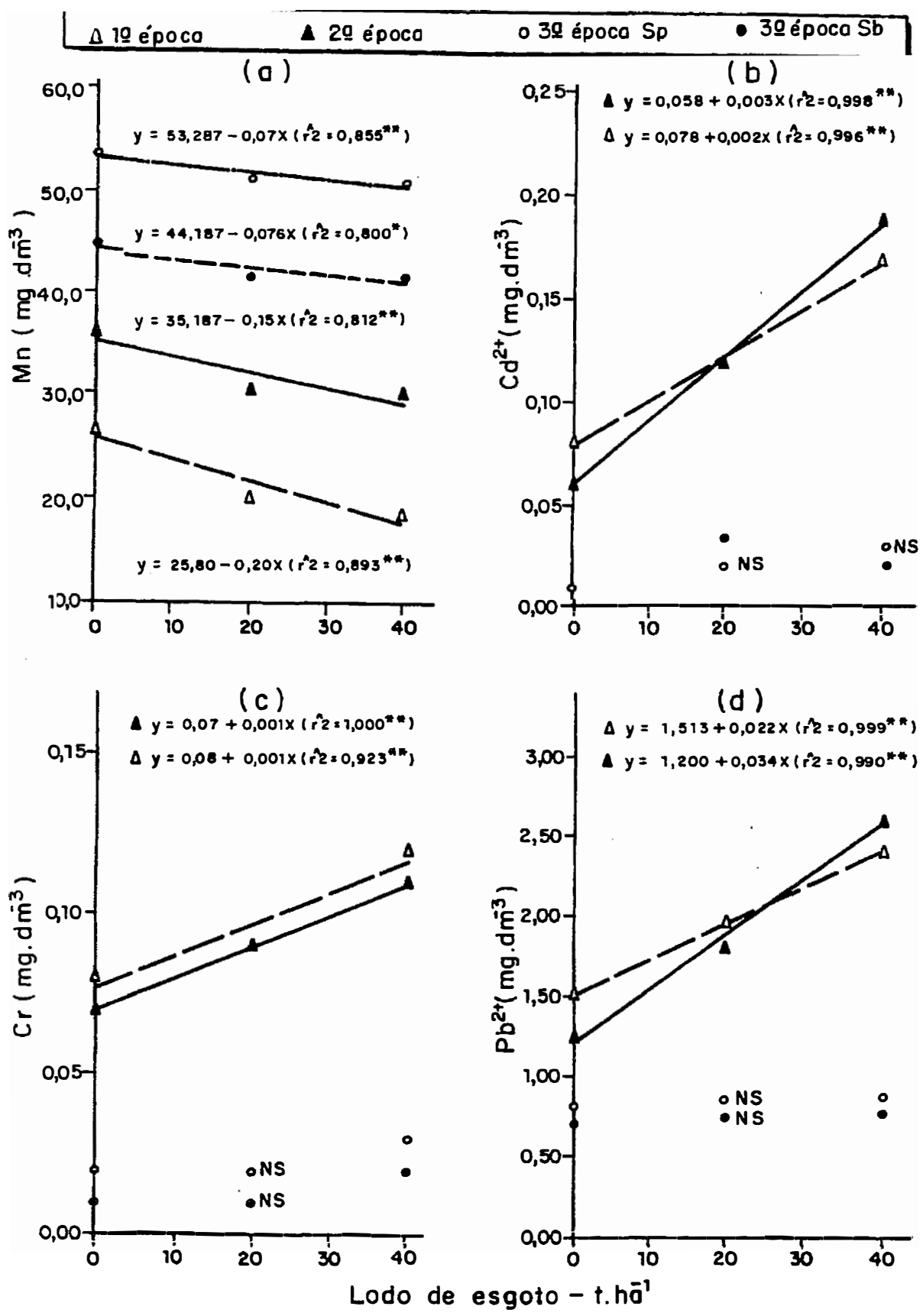

Figura 4- Influêncio da oplicaçōo de doses de esgoto nos teores de manganês(a), de códmio (b), de crômio (c) e chumbo (d) no solo, extraidos por DTPA $\mathrm{pH} 7,3$, oos 146, 272 e 484 dap.

*-significativo a $5 \%$ de probabilidade, no teste $F$ **-significativo a $1 \%$ de probabilidade, no teste $F$ NS-nōo significativo, no teste $F$ $\mathrm{Sp}$-amostra de superfície de $\mathrm{O}$ o $20 \mathrm{~cm}$ Sb-amostra de superfície de 20 a $50 \mathrm{~cm}$ 


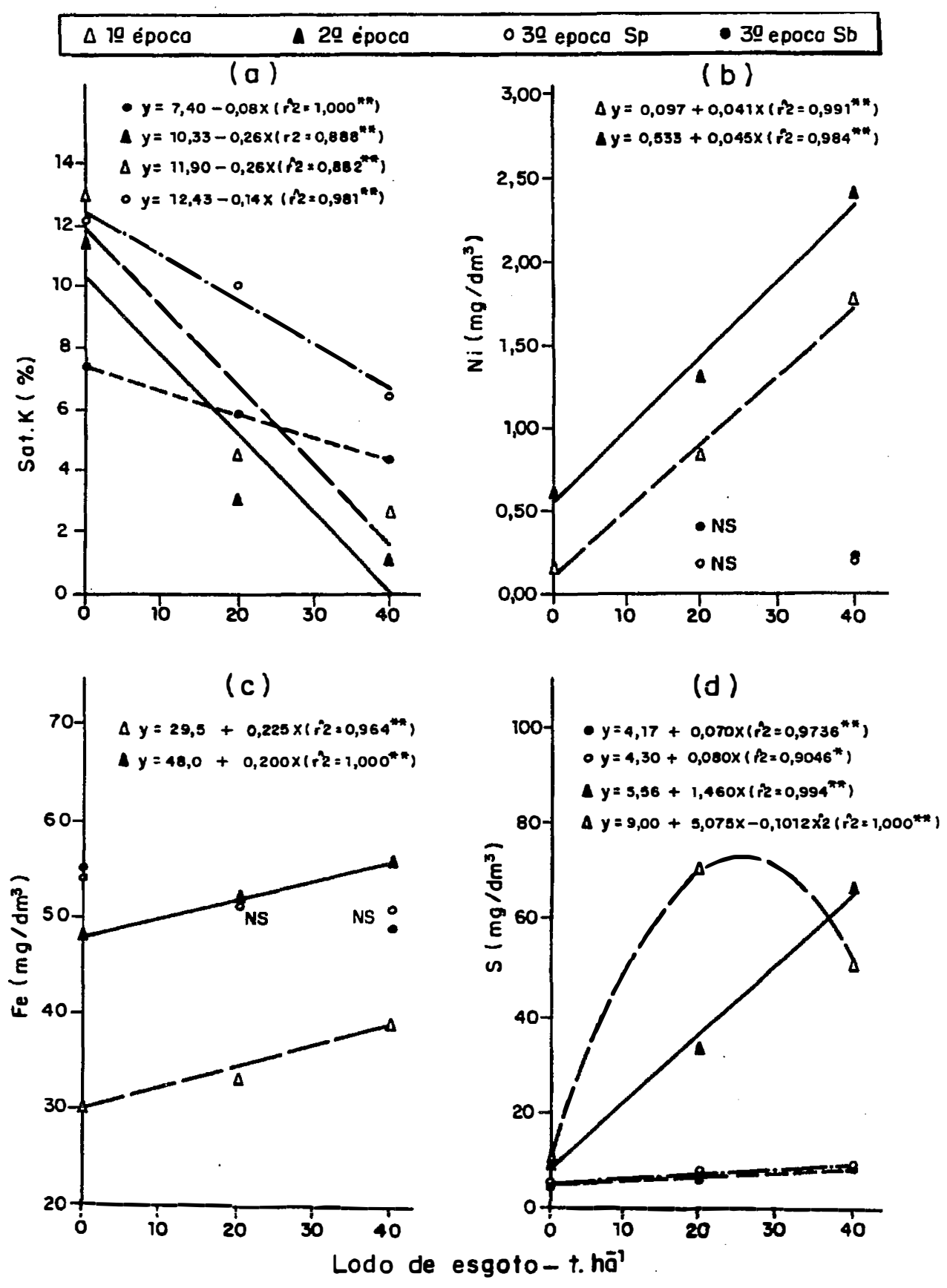

Figura 5-Influência da aplicaçõo de doses de lodo de esgoto na saturaçāo de potóssio (a) e teores de níquel (b), de ferro(c) e enxofre (d) no solo, oos 146, 272 e 484 dap.

*-significativo a $5 \%$ de probabilidade, no teste $F$.

* *-significativo a $1 \%$ de probabilidade, no teste $F$.

NS-nāo significativo, no teste $F$.

Sp-omostra de superficie de 0 a $20 \mathrm{~cm}$

Sb-amostra de superficie de 20 a $50 \mathrm{~cm}$ 
Inicialmente, verifica-se nas Figuras 2c e 6d, que o Le promoveu aumento drástico no valor da CTC, atingindo o valor máximo ao redor de 250 dias após o plantio (dap). Este efeito foi passageiro pois na amostragem final, feita após a colheita da cana-de-açúcar, a CTC já havia retornado a valor próximo do inicial ( Figura 6d), fato também observado por MELO \& MARQUES(1992). O aumento da CTC, proporcional à dose aplicada de Le no solo não surpreende, pois esse resíduo é um material que possui cargas negativas devidas aos radicais $\mathrm{R}^{-\mathrm{COO}^{-}}$e R-O- (MELLO et al., 1988). O que surpreende foi o fato de ter havido curta duração deste efeito ou seja, mesmo na dose de 40 t.ha $^{-1}$ de Le, e de haver maior diminuição de CTC em um período curto de tempo, entre a $2^{a}$ e $3^{a}$ amostragens de solo (Figura 6d). A queda da CTC a partir de 250 dap, poderia ser explicada pela decomposição rápida e o predomínio do processo de polimerização da fração húmica liberada pela matéria orgânica, após 250 dias da aplicação do Le. Estes mesmos acontecimentos foram observados por MELO et al.(1994), verificando que, na dose de 32 t.ha ${ }^{-1}$ de Le, o aumento de CTC do solo correlacionou-se com a fração húmica $\left(r=0,59^{\star}\right)$ da matéria orgânica, o que se tornou mais evidente até 230 dias o que, segundo o autor, prevaleceria então o processo de polimerização do material orgânico contido no Le. Portanto, a mineralização e as formas presentes da matéria orgânica são partes importantes das mudanças ocorridas no complexo coloidal. Ë interessante assinalar que pela análise do solo não se constatou a variação no teor de matéria orgânica que explicasse a alteração da CTC, o que também foi observado por DIAS (1994). 


$\Delta$ Testemunhols/Le) $\Delta 20$ t/ho Le 040 t ha Le

(a)

$\Delta y=4,1+0,002 \times(\hat{r}=0,994 *)$

- $y=4,109+0,014 x-0,0001)\left\langle 2\left(\hat{r} 2=0,940^{* *}\right)\right.$

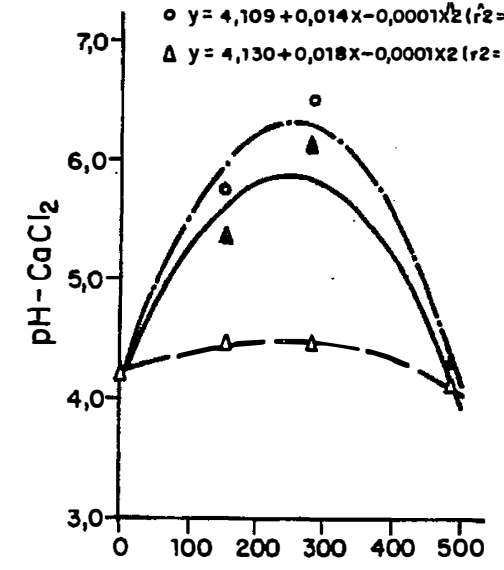

(b)

- $y=18,9+4,8 x-0,01 \times \hat{2}(\hat{f} 2=0,887 * \ldots)$

$\left.\Delta y=38,9+2,9 x-0,01 x^{\hat{2}}(\dot{r} 2=0,92)^{\text {knx }}\right)$

$\Delta y=62, B+0,2 x\left(\hat{r} 2=0,709^{*}\right)$

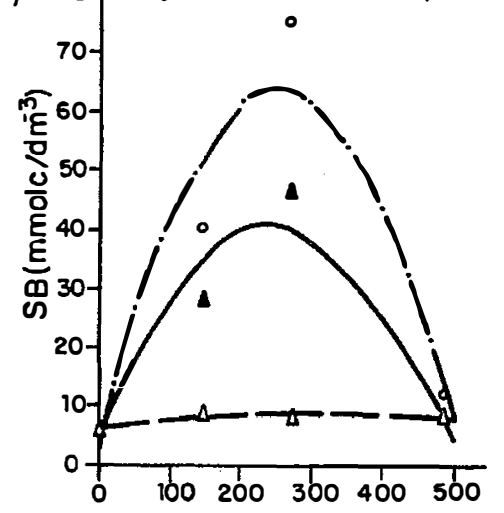

(C) $0 y=24,51+0,436 x-0,001 x^{\hat{2}}\left(\hat{r} 2=0,99 \theta^{\text {** }}\right)$

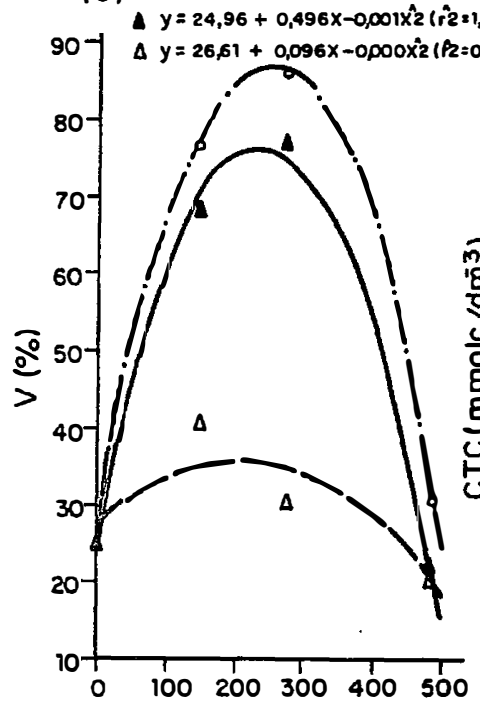

(d)

(e)

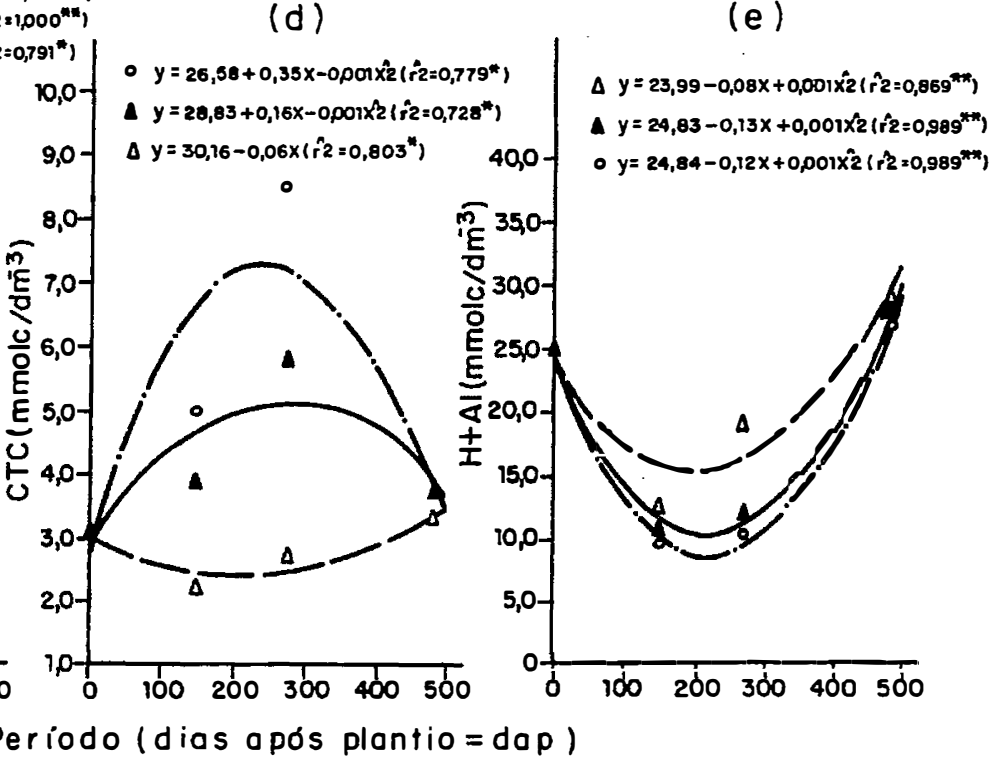

Figura 6-Influêncio da aplicaça de doses de lodo de esgoto na acidez ativa ( $p H=a)$, no soma $(S B=b)$, e soturação de bases $(V \%=c)$, capacidade de troco catiônica $(C T C=d)$ e acidez potencial $(H+A l=e)$ no solo, com decorrer do tempo (dap).

* significativo a $5 \%$ de probabilidade, no teste $F$. * * significativo a $1 \%$ de probabilidade, no teste $F$. 
De forma semelhante ao ocorrido para a CTC, ocorreu também uma variação muito grande na $V$ motivada pelo uso do Le (Figuras $2 d$ e 6c). Houve a elevação do seu valor inicial baixo, até atingir o valor máximo, considerado alto e mesmo acima da exigência da cana-de-açúcar. Posteriormente houve queda, retornando ao valor inicial do solo. Estas variações observadas são conseqüências dos aumentos significativos de cátions adsorvidos ao complexo coloidal do solo, o que pode ser visto nas Figuras $2 b$ e $6 b$, preparadas com os resultados da SB. Observam-se ainda as variações do pH (Figuras 1a e 6a) e da H+Al do solo (Figuras 1b e 6e).

Ressalte-se que a ação do Le no solo promoveu simultaneamente os aumentos da $\mathrm{SB}$ e do índice $\mathrm{pH}$ e a redução da $\mathrm{H}+\mathrm{Al}$, ocorrências essas que podem ser explicadas em dois aspectos distintos associados ao resíduo. Primeiramente, pela ação inicial do Le, adicionando ao solo cátions e sendo seus componentes do tipo base forte pela própria alcalinidade do material $(\mathrm{pH}>10$ ). Lembre-se que no processo de geração do Le adiciona-se até $6 \%$ de $\mathrm{CaO}$ no processamento das águas servidas (SABESP, 1979). Com o passar do tempo, deve predominar outro fenômeno, ou seja, o de oxidação do carbono que, a exemplo do que ocorre também com a vinhaça no solo, pode ser explicado pela introdução de limitada reserva deste composto contido no resíduo apto a ser oxidado no solo (GLORIA, 1992), levando, deste modo, a uma neutralização temporária da acidez do solo. O processo ocorrerá enquanto houver liberação de elétrons pela carga orgânica que seriam recepcionados pelo $\mathrm{H}^{+}$do complexo coloidal que passaria a $\mathrm{H}_{2}$, ou indiretamente pela recepção de $\mathrm{O}_{2}$ que formaria íons oxigênio, que reagem com $\mathrm{H}^{+}$, resultando em 
$\mathrm{H}_{2} \mathrm{O}$. Com isto haveria uma redução na $\mathrm{H}+\mathrm{Al}$ e aumentaria o pH do solo. A teoria proposta por GLÓRIA (1992) foi confirmada para o comportamento do Le no solo, pelos resultados de MELO et al. (1994) e de ROS et al. (1993), que verificaram que o citado residuo tinha efeito no solo por curto espaço de tempo.

Verifica-se então que os efeitos da aplicação do Le sobre o complexo coloidal tem curta duração, pois após 1 ano da sua aplicação ao solo, os efeitos já haviam desaparecidos, sendo os valores iguais ao da testemunha, como se pode verificar pela V\% (Figura 6c), SB (Figura 6b), H+Al (Figura 6e) e pH (Figura 6a).

As duas bases adicionadas ao solo pelo Le, responsáveis pelo aumento da SB e da V do solo são o Ca (Figuras 1c e 7c) e o Mg (Figura 1d), principalmente o primeiro, que teve em seu teor trocável um aumento, em relação à testemunha, de 8 vezes (1 ${ }^{\text {a }}$ amostragem) e quase 4 vezes ( $2^{\text {a }}$ amostragem), quando a dose de 40 t.ha ${ }^{-1}$ de Le foi aplicada. No Le, o Ca e o Mg são os dois cátions que aparecem em maior concentração. O Le foi pobre em K e com a aplicação deste resíduo no solo houve mesmo redução da disponibilidade do elemento (Figura 2a) e a sua participação na saturação em bases (Figura 5a), apesar do teor de $\mathrm{K}$ ainda permanecer na classe considerada baixa ( $<1,5 \mathrm{mmol}_{d} / \mathrm{dm}^{3}$. Saliente-se que o Le tem Ca e $\mathrm{K}$ que foram extraídos pelo método da resina obteve-se no residuo respectivamente 36,7 e 1,5 $\mathrm{mmol}_{\mathrm{c}} / \mathrm{dm}^{3}$, porém não tem $\mathrm{Mg}$ prontamente extraivel pelo mesmo extrator. Era de se esperar alto teor de Ca no Le, pois no final do tratamento das águas servidas há adição de $\mathrm{CaO}$, o que propiciou ao Le que $63 \%$ do $\mathrm{Ca}$ total fossem imediatamente extraiveis pela resina. 


\begin{tabular}{|lll|}
\hline$\Delta$ Testemunho(s/Le) & $\Delta 20$ t/ho Le & 040 t/ha Le \\
\hline
\end{tabular}

(a)

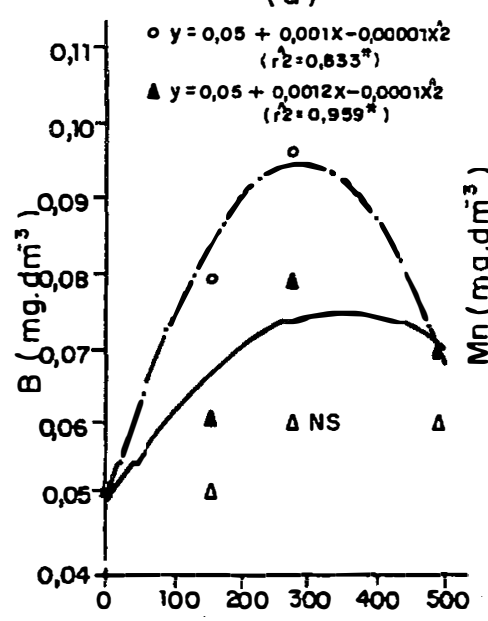

(d)

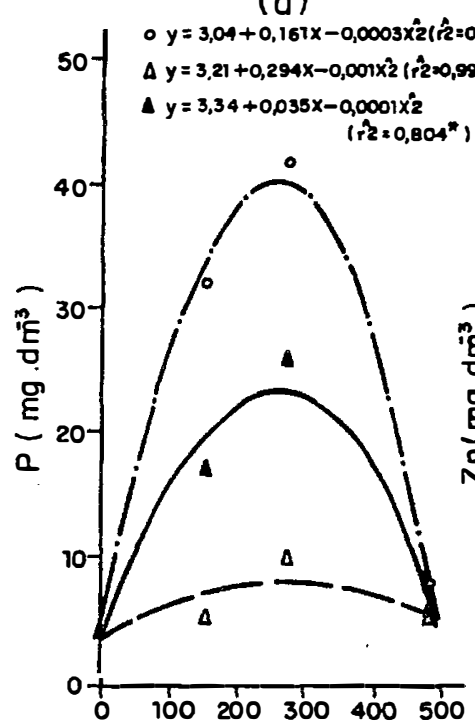

(b)

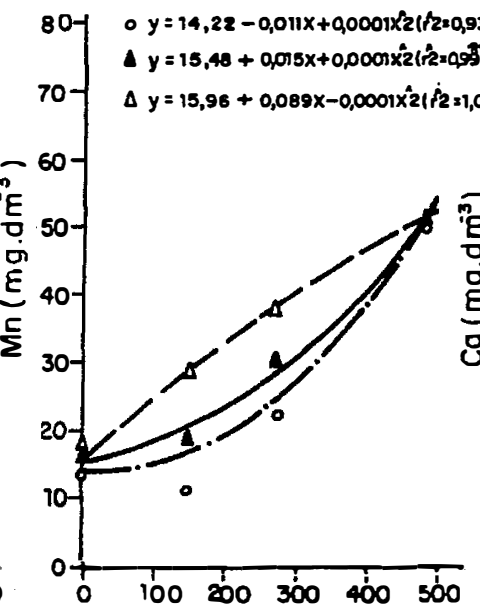

(e)

$\Delta y=0,500+0,001 x+0,0001 \times \hat{2}\left(\hat{r}_{2}=0,982^{*}\right)$ $\Delta y=0,852+0,025 x-0,0001 \times \hat{2}\left(\dot{r} 2=0,54 t^{n}\right), 80$ - $y=1,178+0,063 x-0,0001 \times 2(r 2=0,800 \mathrm{~mm})$ (c)

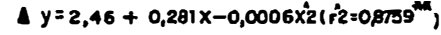
$\Delta y=3,38+0,398 x-0,0008 \times \hat{2}\left(\hat{r} 2=0,973^{n+m}\right)$

$0 y=4,93+0,021 \times\left(\dot{r} 2=0,980^{\prime \prime}\right)$

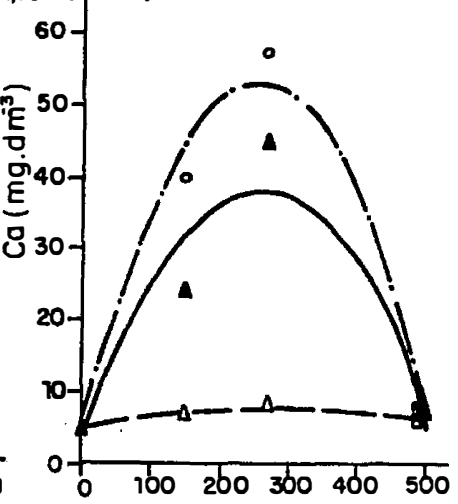

( $f$ )

$\Delta y=3,4591+0,0484 x-0,0001 \times \hat{2} 2(\hat{r} 2=0,8723$ ) - $y=1,4876+0,4783 x-0,001 \times \hat{2}$ (í2 $\left.=0,983 \hat{3}^{4}\right)$

$\Delta y=9,7753+0,3749 x-0,0008 \times 2(\hat{r} 2=0, \oplus 1010)$
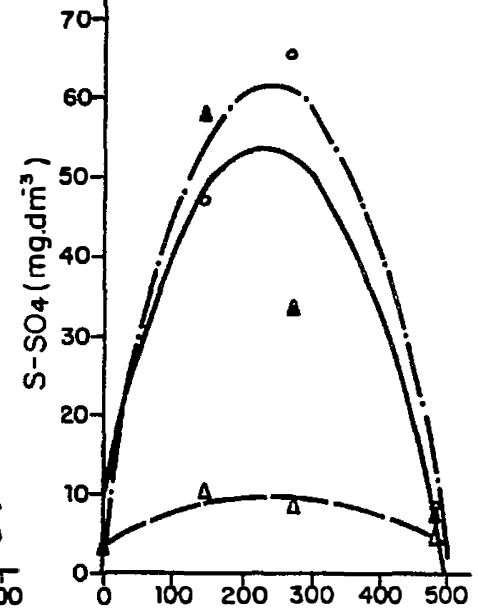

Periodo (dias após plantio $=$ dap)

Figura 7-Influência da aplicação de doses de lodo de esgoto nos teores de boro(o), de manganês (b), de cálcio (c), de fósforo (d), de zinco (e) e na enxofre (f) no solo, com o decorrer do tempo (dap).

* significativo o $5 \%$ de probabilidade, no teste $F$. * * significativo o $1 \%$ de probabilidade, no teste $F$. NS não significativo, no teste $F$. 
Constata-se também neste aspecto que o efeito do Le se restringe ao periodo de 1 ano, como se pode verificar pelos teores de Ca do solo que voltaram aos valores iniciais (Figura 7c). Por outro lado, é difícil explicar as diminuições drásticas ocorridas nos teores de $\mathrm{Ca}$ e $\mathrm{Mg}$ do solo, quando se comparam as amostragens aos 272 dap e 484 dap, porque foram adicionadas as quantidades totais de $175 \mathrm{~kg}$ de Ca e de $53 \mathrm{~kg}$ de $\mathrm{Mg}$, ao se aplicar à dose de 40 t.ha $^{-1}$ de Le. A única explicação possivel seria a lixiviação destas bases num espaço de tempo relativamente curto, entre a $2^{a}$ e $3^{a}$ amostragens do solo, já que ocorreu chuva neste periodo, como pode ser comprovado pelos dados meteorológicos . Se o fenômeno de fato ocorreu, a análise química das amostras da subsuperfície $(20-50 \mathrm{~cm})$, da $3^{\text {a }}$ época (aos 484 dap) teria detectado aumento dos teores desses elementos nesta camada no tratamento com Le, mas isto não ocorreu, como se pode notar nas Figuras 1c e 1d. A outra possivel explicação relaciona-se aos reflexos da decomposição da matéria orgânica do Le que permitiria a formação de complexos orgânicos com os cátions no solo. Deste modo, os cátions teriam um comportamento no solo semelhantes a CTC, no decorrer do tempo após a aplicação do resíduo. Os nutrientes poderiam ainda ser incorporados ao complexo coloidal do solo e a biomassa microbiana. No caso dos nutrientes que foram absorvidos pelas plantas podem ter sido acumulados preferencialmente nas raizes.

As quantidades totais dos demais nutrientes adicionados ao solo pela dose de 40 t.ha $^{-1}$ de Le foram $334 \mathrm{~kg} \cdot \mathrm{ha}^{-1}$ de N, $152 \mathrm{~kg} \cdot \mathrm{ha}^{-1}$ de P, $23 \mathrm{~kg} \cdot \mathrm{ha}^{-1}$ de K, $152 \mathrm{~kg} \cdot \mathrm{ha}^{-1}$ de S, $775 \mathrm{~kg} \cdot \mathrm{ha}^{-1}$ de Fe e 129 g.ha ${ }^{-1}$ de B. Destas quantidades totais adicionadas, apenas uma pequena parte foi extraida por resina ou por soluções 
extratoras. Assim, de fato prontamente solúvel naqueles extratores aplicou-se 0,5 kg.ha-1 de P, 0,9 kg.ha' ${ }^{-1}$ de K, 0,7 kg.ha-1 de Fe e 75 g.ha-1 de B. Saliente-se que as quantidades de nutrientes prontamente disponiveis no Le são baixas, por se encontrarem no citado residuo preferencialmente precipitados (COTTENIE, 1981), o que pode ser explicado pela alcalinidade do Le.

Quanto ao efeito desta adição de $P$, verifica-se nas Figuras $3 a$ e 7d que há aumento considerável no teor do elemento extraido pela resina, pois passou de teores considerados baixos (<15) para teores médios (RAlJ et al., 1989), quando a dose mais alta de Le foi aplicada. Resultados semelhantes foram obtidos por MELO \& MARQUES (1992). Isto demonstra que, pelo menos em parte, o $P$ do Le foi disponivel aos vegetais, que normalmente encontra-se nele como polifosfato originário, na sua maioria, de detergentes (AYUSO et al., 1992). Ressalte-se que foi pouca a contribuição imediata do Le como fornecedor de $\mathrm{P}$ ao solo, quando foi extraido pela resina esteve ao redor de $21 \mathrm{mg} / \mathrm{dm}^{3}$, indicando que a liberação do elemento a ser absorvido pelas plantas dá-se gradualmente com o decorrer do tempo pelo processo de mineralização das formas orgânicas do fosfato. BOARETTO (1986) verificou que do total adicionado que foram aproveitados pelas plantas 7 a $59 \%$ para a soja, $10 \%$ para 0 arroz e $7 \%$ para o feijão. Segundo LOGAN \& MATTIAZZO-PREZOTTO (1992), $50 \%$ do total adicionado ao solo no composto de Le com resíduo de cimento, o P poderia ser absorvido pelas forrageiras. Entretanto, saliente-se que o $\mathrm{P}$ fornecido pelo Le e disponivel à cultura de cana-de-açúcar deve ser maior que a fração aproveitada pela soja e mesmo pela forrageira, pois esta graminea tem ciclo maior e o seu sistema radicular é muito desenvolvido. 
Verifica-se pela Figura 7d, que houve efeito do Le no teor de P do solo, efeito que é também de curta duração, o que foi verificado por MELO \& MARQUES (1992). Neste caso, poderia se prever sobre uma possivel fixação do $P$. Inicialmente, o P estaria protegido por estar na forma de polifosfato, já que a matéria orgânica bloquearia os sítios de adsorção especifica para o elemento no solo (TISDALE \& NELSON, 1975). Entretanto, com o passar do tempo a matéria orgânica se polimeriza ou se decompõe, liberando o $\mathrm{P}$ e os sítios de adsorção favorecendo a sua fixação e dai o elemento torna-se pouco extraivel pela resina. Ressalte-se que, apesar de não se ter avaliado a composição do sistema radicular, parte do $\mathrm{P}$ como de vários nutrientes pode ter sido acumulada nas raizes da cana (MALAVOLTA, 1994), como foi observado em sorgo granifero (DIAS, 1994)..

Algo semelhante ao que ocorreu ao $\mathrm{P}$ também foi observado para o $\mathrm{S}$ (Figuras 5d e 7f). Os teores de $S$ no solo, que inicialmente eram da classe de teor baixo, pelo critério de KLIEMANN (1987) foram aumentados pela adição do Le. Este autor encontrou como nivel crítico no solo o teor de $19 \mathrm{mg} \cdot \mathrm{kg}^{-1}$ (extraído em $\mathrm{CaCl}_{2}$ 1,5 g. $\mathrm{kg}^{-1}$ ) para o milho. No presente experimento, este valor foi atingido aos 114 e 254 dap com a dose de 20 t.ha $^{-1}$ de Le. Ao final do cultivo estes efeitos do Le nos teores de $S$ extraído do solo não se faziam sentir, indicando a possibilidade de perda por lixiviação, como $\mathrm{SO}_{4}{ }^{2-}$. Isto pode ter ocorrido pela formação de par iônico com Ca e $\mathrm{Mg}$, por exemplo, mas permanece ainda a suspeita de que este composto esteja relacionado com o complexo coloidal do solo e a incorporação pela biomassa microbiana, como já explicado anteriormente quando se discutiu o $\mathrm{Ca}, \mathrm{Mg}$ e $\mathrm{P}$. Isto porque, se o primeiro aspecto fosse verdadeiro, nas amostras de solo da 
subsuperficie $(20-50 \mathrm{~cm}$ de profundidade), retiradas aos 484 dap, ocorreriam o enriquecimento em S, o que não aconteceu. $\quad$ L Le como fornecedor de $S$ ao solo foi anteriormente observado por DIAS (1994).

Em relação aos micronutrientes do solo extraídos por DTPA : Cu( Figuras 3c e 8f), Zn (Figuras 3b e 7e), Fe (Figuras 5c e 8c) e Ni (Figura 5b e 8d), verificam-se efeitos positivos do Le. Explicam-se estes efeitos pelo fato do material orgânico empregado conter tais elementos, o que corresponderia a uma aplicação em kg.ha-1 dos metais, na dose de 40 t.ha $^{-1}$ do Le, de : 7 de Ni, 14 de $\mathrm{Cu}, 28$ de $\mathrm{Zn}$ e 750 de Fe. Entretanto, somente parte dos metais presentes no Le foi extraída pelo DTPA. Isto foi comprovado pela comparação entre os teores totais dos microelementos do Le com os teores extraídos pelo DTPA. Poder-se-ia dizer que $15 \%$ de $\mathrm{Ni} ; 9 \%$ de $\mathrm{Cu} ; 12 \%$ de $\mathrm{Zn} ; 7 \%$ de $\mathrm{Mn}$ e $0,1 \%$ de $\mathrm{Fe}$, são disponiveis nos solos, isto é, mais de $90 \%$ dos micronutrientes, em forma não extraída, possivelmente estariam precipitados, como observou COTTENIE (1981).

O fornecimento de micronutrientes pelo Le ao solo foi notável e importante, principalmente Zn (Figuras 3b e 7e) e Cu (Figuras 3c e 8f), fato também observado por NIKITIN (1960). Os aumentos poderiam ser maiores ainda, se o Le não alterasse também $\circ \mathrm{pH}$ do solo, que se sabe ter influência sobre o $\mathrm{Cu}, \mathrm{Zn}, \mathrm{Fe}$ e $\mathrm{B}$, diminuindo-se suas disponibilidades à medida que aumenta o pH (LINDSAY, 1972 ;MALAVOLTA, 1980 e MELLO et al., 1988). Os aumentos não tão expressivos de Zn e de $\mathrm{Cu}$, devido ao Le, que teoricamente poderiam ser esperados, podem ser explicados pela reduzida capacidade de tamponamento do solo empregado (Pva), pois houve um aumento do pH já comentado. Com a elevação do pH', há diminuição 
da disponibilidade dos micronutrientes citados, os quais se precipitam no solo. Os metais que não foram precipitados devem estar preferencialmente associados à fração orgânica, na forma de complexos (STEVENSON \& ARDAKANI, 1972). Porém, com o tempo, os componentes orgânicos introduzidos pelo Le já estariam polimerizados, liberando os metais que então seriam insolubilizados, refletindo em diminuição de suas disponibilidades, conforme pode ser visto nas Figuras $6 e$ (Zn), 7a (B), $8 f(\mathrm{Cu})$ e $8 a(\mathrm{Ni})$.

No caso específico do Mn (Figura 4a), apesar do Le contê-lo em sua composição, o efeito do $\mathrm{pH}$ foi mais forte, a ponto de haver diminuição do seu teor extraído do solo com DTPA, em função do aumento da dose do Le. O teor de Mn solúvel em DTPA no solo foi influenciado significativamente pela época de amostragem $\left(F^{\star \star}\right)$ e pelo uso de Le, como se observa na Figura. $7 b$, onde se verifica uma redução da disponibilidade de $\mathrm{Mn}$ no solo, face ao aumento das doses deste resíduo. Como se verificou, o comportamento do Mn foi oposto ao observado para $\mathrm{Zn}, \mathrm{Cu}, \mathrm{Fe}$ e B. A causa que pode ter motivada esta diferença seria a maior influência da elevação do pH do solo sobre o Mn. Uma outra possivel explicação seria a preferência da matéria orgânica em ligar-se ao $\mathrm{Cu}$ e $\mathrm{Zn}$ para a formação de complexos orgânicos com ácidos húmicos e fúlvicos, oriundos da sua mineralização no sistema (AUBERT \& PINTA, 1977 ; MANAHAN, 1990 e LUCAS \& NEZER, 1972), o que levaria o Mn comportar-se no solo mais independente da carga orgânica contida no Le e, portanto, mais sujeito à insolubilizacão.

A redução da disponibilidade dos metais pesados $(\mathrm{Cu}, \mathrm{Zn}, \mathrm{Mn}$ e $\mathrm{Fe})$ nas amostras do solo, a partir de $\mathbf{2 5 0}$ dap, podem também serem relacionadas com as já 
discutidas questões da acumulação relativa dos metais nas raizes e a incorporação dos mesmos ao complexo coloidal do solo e a biomassa microbiana.

Numa análise conjunta dos micronutrientes analisados, podem-se verificar os efeitos do Le nos niveis de suficiência dos mesmos no solo, com base na tabela de interpretação modificada, que foi elaborada por MALAVOLTA(1994). A citada tabela foi elaborada tendo como base os resultados obtidos pelo extrator de Mehlich 1, que tem correlação com os teores extraídos pela solução de DTPA pH 7,3 (BATAGLIA \& RAIJ, 1983). É necessário que seja levado em consideração que o extrator de Mehlich 1 extrai os micronutrientes em quantidades menores que o DTPA; portanto, recalculou-se a partir das faixas adequadas estabelecidas por MALAVOLTA(1994) e obteve-se: Fe (65 a 126), Cu (1,6 a 3,2), Mn (18 a 35) e Zn (2,0 a 3,0), sendo estes expressos em $\mathrm{mg} \mathrm{kg}^{-1}$ de terra. Não foi possivel estimar a faixa de adequação para os teores de B no solo, devido não se conhecer a correlação entre o valor estabelecido por MALAVOLTA (1994) usando um extrator, enquanto que os resultados do $B$ no presente ensaio foram extraídos em cloreto de bário em forno de microondas e determinados por colorimetria com curcumina ( IAC, 1994).

Deste modo, podem-se classificar os teores encontrados nos solos amostrados nas parcelas sem adição de Le como suficientes para o Mn (Fig. 7b) e para o Fe (Fig. 8c) , mas inferiores ao necessário para o Cu (Fig. 8f) e o Zn (Fig. 7e). Com a adição de 40 t.ha $^{-1}$ de Le os niveis de suficiência no solo elevaram-se, tornando-os suficiente para a cultura da cana-de-açúcar para o $\mathrm{Cu}$ e o Zn, conforme estabelecido por MARINHO \& ALBUQUERQUE, (1978), realizando ensaios em solos de tabuleiro èm Alagoas. 
Tomando-se por base agora os niveis totais no solo que poderiam causar fitotoxidez, estabelecidos por PEPIN \& COLEMAN (1984), em mg.kg-1, podese verificar que os mesmos eram menores que as faixas limites, que são: $\mathrm{Cu}$ (60 125), Zn (70-400), e Mn (1500-3000). Os valores máximos para o $\mathrm{Cu}, \mathrm{Zn}$ e $\mathrm{Mn}$

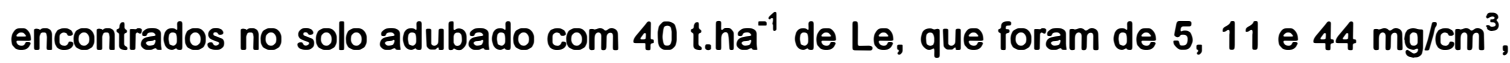
representam uma margem de segurança de 12,7 e 30 vezes os valores críticos ( PEPIN \& COLEMAN, 1984 e MALAVOLTA, 1994), respectivamente.

Numa análise mais generalizada pode-se dizer que a adubação potássica, em complementação ao uso do Le era necessária, pois este residuo é pobre nesse macronutriente e o solo empregado tinha um teor inferior ao nivel de suficiência de $2,1 \mathrm{mmol}_{\mathrm{c}} \mathrm{K}^{+} / \mathrm{dm}^{3}$ de terra que é necessário à cultura (RAlJ et al., 1974 e 1989). Devido a este aspecto, pode-se deduzir que a pobreza de $\mathrm{K}$ no Le poderia limitar a sua aplicação isolada como fertilizante (BUNTING, 1963), problema também ressaltado por diferentes autores, como LINDEN et al. (1983), ROS et al.(1990), BOARETTO (1986), WILLSON et al. (1980) e IPT/CETESB (1983).

Quanto à complementação do Le com $\mathrm{P}$, pode-se verificar pelos resultados analíticos do solo que não haveria necessidade, pois o Le ao ser aplicado em quantidades acima de 20 tha $^{-1}$, já forneceria quantidades suficientes deste nutriente ao solo para se ter niveis compativeis com as exigências da planta. Verificou-se ainda que o Le adiciona, se aplicado em doses acima de 20 t.ha $^{-1}$, quantidades adequadas de $\mathrm{Ca}, \mathrm{Mg}, \mathrm{S}$ e micronutrientes. 


\subsection{Metais Pesados no Sistema Solo-Planta e o Lodo de Esgoto}

A definição química de "metais pesados", encontrada em MATTIAZZOPREZOTTO (1992) e MALAVOLTA (1994), engloba os metais, semi-metais e não metais, incluindo-se $\mathrm{Cd}, \mathrm{Ni}, \mathrm{Pb}, \mathrm{Se}, \mathrm{Al}$ e os micronutrientes ( $\mathrm{Cu}, \mathrm{Fe}, \mathrm{Mn}$, Mo e $\mathrm{Zn}$ ). Alguns autores consideram o Ni como elemento essencial para as leguminosas, pois participa da enzima urease, porém, outros autores o consideram como elemento benéfico (MALAVOLTA, 1994).

O Ni contido no Le, embora estivesse pouco acima do limite máximo da Legislação. Americana que estabelece normas para o uso agronômico deste resíduo (ESTADOS UNIDOS, 1993), não significa que na dose aplicada do Le chegue os metais a niveis no solo que se tornem tóxicos à cana-de-açúcar, porque apenas $15 \%$ do Ni, foi extraído do Le pelo DTPA. Porque os metais pesados não são absorvidos proporcionalmente pelas plantas em relação aos seus teores no solo (BECKETT, 1991).

Na Tabela 4, verifica-se que foram adicionados 6,8 kg.ha- ${ }^{-1}$ de $\mathrm{Ni}$, quando se aplicaram 40 t.ha $^{-1}$ de Le e o teor de Ni extraído com DTPA foi de 2,3 $\mathrm{mg} \cdot \mathrm{dm}^{-3}$ de terra , bem menor que o teor máximo aceitável no solo, independente da fonte consultada. Deste modo, o teor de Ni encontrado no solo não oferece risco de contaminação do ambiente e está dentro da faixa de variação encontrada para a média dos solos paulistas ( ROVERS et al. , 1983). 
Os teores médios no solo para os demais metais pesados ( $\mathrm{Cd}, \mathrm{Cr}, \mathrm{Ni}$ e $\mathrm{Pb}$ ), elevaramse pela adição de Le, como se nota nas Figuras 4b, 4c, 4d e 5b. Pela análise estatística dos teores no solo de cada metal pesado, os valores foram significativamente afetados pela adição de $\operatorname{Le}\left(F^{\star \star}\right)$, época $\left(F^{\star \star}\right)$ e pela interação Le $x$ época $\left(F^{\star *}\right)$, como se verifica no Apêndice 3, na camada de terra de 0 a $20 \mathrm{~cm}$ de profundidade.

Tabela 4. Enriquecimento do solo após aplicação de 40 t.ha $^{-1}$ de Le (úmido)

\begin{tabular}{|c|c|c|c|c|c|}
\hline \multirow[t]{3}{*}{ Elemento } & \multirow{3}{*}{$\begin{array}{c}\text { Conteúdo no } \\
\text { Le } \\
\mathrm{mg} \cdot \mathrm{kg}^{-1} \text { de MS }\end{array}$} & \multirow{3}{*}{$\begin{array}{c}\text { Quantidade de } \\
\text { metal aplicada } \\
\text { kg.ha' }\end{array}$} & \multirow{3}{*}{$\begin{array}{c}\text { Teor no solo, } \\
\text { aos } 272 \text { dap } \\
\text { mg.dm }\end{array}$} & \multicolumn{2}{|c|}{$\begin{array}{l}\text { Quantidade máxima aceitável } \\
\text { em teor total no solo }\end{array}$} \\
\hline & & & & (1) & (2) \\
\hline & & & & \multicolumn{2}{|c|}{$\mathrm{mg} \cdot \mathrm{kg}^{-1}$} \\
\hline $\mathrm{Cd}$ & 25 & 0,4 & 0,2 & 3 & $3-8$ \\
\hline $\mathrm{Ni}$ & 445 & 6,8 & 2,5 & 50 & 100 \\
\hline $\mathrm{Cu}$ & 905 & 13,8 & 5 & 50 & $60-125$ \\
\hline $\mathrm{Cr}$ & 645 & 9,8 & 0,2 & 100 & $75^{-} 100$ \\
\hline $\mathrm{Pb}$ & 265 & 4,0 & 2,5 & 200 & $100-400$ \\
\hline Mn & 505 & 7,7 & 28 & 400 & $1500-3000$ \\
\hline $\mathrm{Zn}$ & 1800 & 27,8 & 9,0 & 300 & $70-400$ \\
\hline $\mathrm{Fe}$ & 50000 & 760 & 39 & - & - \\
\hline
\end{tabular}

FONTE: (1) COTTENIE, 1981 e (2) PEPIN \& COLEMAN, 1984. 
Nota-se nas Figuras $8 a, 8 b, 8 d$ e $8 e$, que em relação à testemunha sem Le, os teores médios de metais pesados encontrados no solo adubado com o citado resíduo, amostrado aos 146 e 272 dap, sofreram a duplicação na maioria dos casos, exceto o $\mathrm{Ni}$ e $\mathrm{Zn}$, que tiveram aumentos de mais de dez vezes. Embora isto tenha acontecido, os teores máximos de $\mathrm{Ni}$ (Fig. 8d) e $\mathrm{Cr}$ (Fig. 8e), Cd (Fig. 8a) e Pb (Fig.8b) estão muito aquém dos teores totais máximos aceitáveis encontrados na literatura mundial (PEPIN \& COLEMAN, 1984 e MALAVOLTA, 1994), como se vê na Tabela 4. Isto quer dizer que os teores de $\mathrm{Ni}, \mathrm{Cr}, \mathrm{Cd}$ e $\mathrm{Pb}$ no solo estão abaixo dos níveis críticos considerados tóxicos às plantas e aos animais que deles se alimentam, oferecendo uma margem de segurança de 33, 25, 6 e 200 vezes os limites propostos pelos autores, respectivamente, para os metais pesados acima citados. Os valores máximos observados no presente trabalho encontram-se dentro da faixa usual de variação dos solos de São Paulo (MATTIAZZO-PREZOTTO, 1994).

Todavia, embora tenha havido efeito linear significativo das doses de Le nos teores de $\mathrm{Cd}, \mathrm{Cr}, \mathrm{Pb}$ e $\mathrm{Ni}$ no solo, pode-se esperar que tais metais irão se acumular principalmente nas raizes das plantas (ADRIANO, 1986; MALAVOLTA, 1994; DIAS, 1994). Com a adição de 40 t.ha $^{-1}$ de Le, os teores de metais pesados no solo foram variáveis no tempo, o que reflete a variabilidade da composição intrínseca do resíduo e velocidade de reação diferenciada dos componentes orgânicos do Le (FULLER \& WARRICK, 1986). A citada variabilidade no comportamento dos metais pesados no solo é indicada nos seus coeficientes de variação considerados como médios ( $\mathrm{Cd}$ e $\mathrm{Pb}$ ) e altos ( $\mathrm{Cr}$ e $\mathrm{Ni}$ ). 


\section{$\Delta$ Testemunho(s/Le) $\quad$ 20t/ho Le - o 40t/ho Le}

(a)

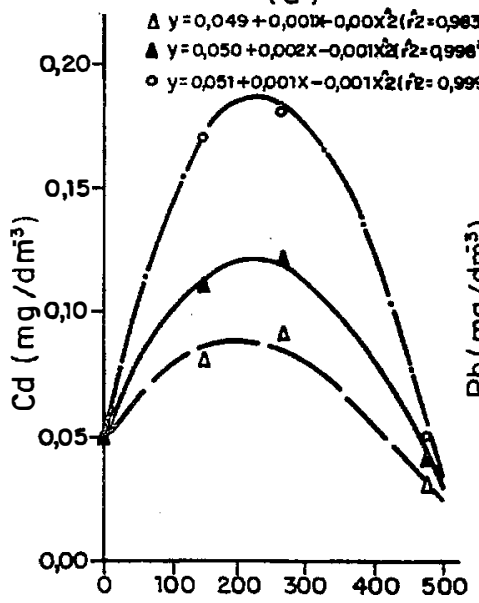

(b)

$\Delta y=1,185+0,011 x-0,0001 \times 2$ (ŕ2*0,990*) $\Delta y=1,191+0,007 x-0,0001 x^{2}\left(\hat{r} 2=0,999^{n * n}\right)$ o $y=1,211+0,003 x-0,0001 \times \hat{2}(\hat{r} 2=0,98 \hat{\theta}) 60$ (c)

$\Delta y=25,65+0,085 x-0,00005 x_{2}(\hat{r} 2=0,926 * *)$ - $y=26,77-0,059 \times\left(r^{2}=0,8511^{* n}\right)$

$\Delta y=26,86+0,097 x-0,0001 x^{\hat{2}}\left(i \dot{z}=0,999^{\mathrm{min}}\right)$
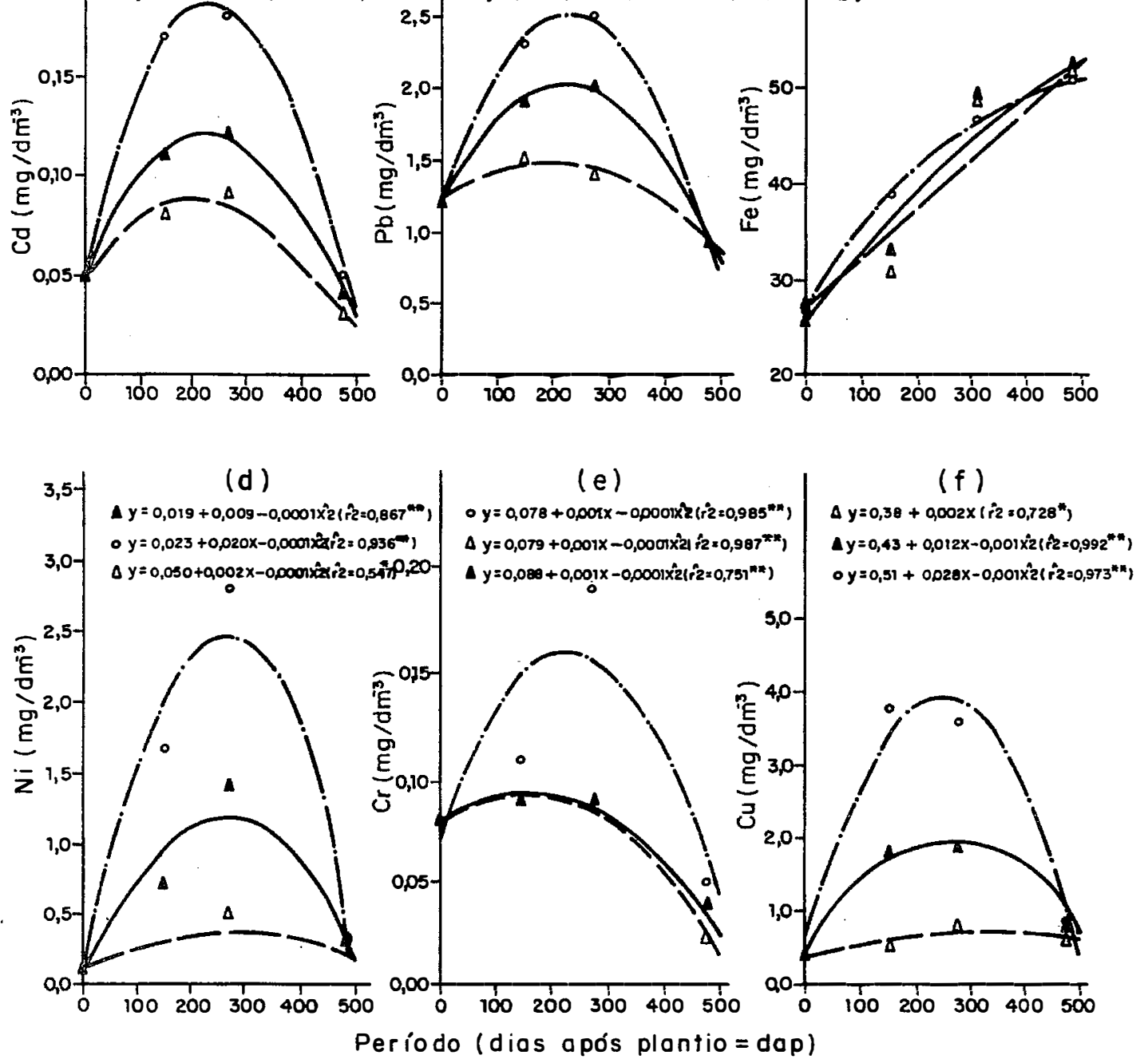

Figura 8 - Influência da oplicaçōo de doses de lodo de esgoto nos teores de cádmio(a), de chumbo (b), de ferro (c), de níquel (d), de crômio (e) e de cobre (f) no solo, com o decorrer do tempo (dap).

*-significativo a $5 \%$ de probabilidade, no teste $F$. **-significativo a $1 \%$ de probabilidade, no teste $F$. 
Após 1 ano do aplicação do Le, na amostragem aos 484 dap (Apêndices 3 e 4), praticamente já haviam desaparecido seus efeitos nos teores dos metais pesados do solo analisado.

Não se observou qualquer efeito no solo da adubação química complementar aos 484 dap ( $F=N S)$, sobre os teores de qualquer dos metais pesados estudados, apesar da literatura dizer que os metais pesados podem ser adicionados ao solo pelos fertilizantes quimicos (MALAVOLTA, 1994; ADRIANO, 1986; entre outros).

Das possiveis conseqüências no sistema solo-planta referentes aos metais pesados contidos no Le, torna-se necessário verificar a passagem destes do solo para a planta. Pela análise das plantas colhidas aos 146 e 272 dap, verificou-se que houve efeito significativo da adição do Le $\left(F^{\star \star}\right)$, da época $\left(F^{* \star}\right)$ e da interação Le $x$ época( $\left.F^{\star}\right)$ nos teores de Se (Fig. 9c), Ni (Fig. 9d) e Cd (Fig. 10e), indicando que estes elementos tóxicos do Le após serem liberados ao solo, foram absorvidos parcialmente pela cana-de-açúcar (Apêndice 5). Os teores foliares encontrados oferecem margem de segurança de 50 vezes o limite inferior para causar a fitotoxidez em espécies sensiveis (ALLAWAY, 1968; LOGAN \& CHANEY, 1983 e ADRIANO, 1986).

Não houve efeito significativo da adição do Le (F=NS) nos teores de $\mathrm{Pb}$ e de $\mathrm{Cr}$ nas folhas, porém, ocorreu diferença significativa para o fator época $\left(\mathrm{F}^{\star}\right)$, embora se verifique uma tendência discreta de elevação dos conteúdos destes 
metais com o aumento da dose do resíduo no solo. Isto indica ação direta dos metais pesados contidos no Le, e os teores foliares só não foram maiores devido à redução de disponibilidade desses metais pela elevação do pH do solo (LINDSAY, 1972 e PAGE et al., 1983).

Ressalte-se que não houve passagem do $\mathrm{Pb}$ e $\mathrm{Ni}$ e, na maioria das vezes, do $\mathrm{Cd} \mathrm{e} \mathrm{Cr}$, para os colmos+folhas ou colmos da cana-planta, pois a correlação entre o teor do elemento no solo e nos tecidos vegetais foi não significativa. Não houve efeito da adição de Le nas concentrações desses metais nos tecidos e nas exportações de $\mathrm{Cd}, \mathrm{Cr}, \mathrm{Ni}, \mathrm{Pb}$ e Se nos colmos+folhas (Apêndice 6), aos 431 dap, e nos colmos (Apêndice 7) aos 469 dap, na cana-planta ( $F=N S$ ). A baixa concentração dos metais pesados nos colmos e colmos + folhas pode ser atribuída à provável concentração nas raízes (MALAVOLTA, 1994) e à limitada absorção de $\mathrm{Cd}^{2+}$ e $\mathrm{Pb}^{2+}$ pela planta, o que pode ser atribuído, em parte, ao efeito de antagonismo com os cátions bivalentes $\left(\mathrm{Ca}^{2+}, \mathrm{Mn}^{2+}\right.$ e $\left.\mathrm{Zn}^{2+}\right)$ no solo (PAGE et al., 1983 e OLIVEIRA et al., 1992).

Finalmente, ressalte-se que os metais pesados que tiveram aumentos de seus teores nos colmos, devido ao uso de Le, estes foram da ordem de valor que não ofereceu qualquer risco de passagem destes metais à cadeia trófica. Tais aspectos, podem ser comprovados nas Figuras 15a a 15j e no Apêndice 6, onde se encontram as quantidades exportadas pelos colmos, considerando-se a produtividade média de matéria seca e de concentração de determinado elemento no tecido para as diferentes doses de Le. É necessário verificar que dentre os metais pesados mais acumulativos nas plantas e que poderiam ser perigosos ao homem, verificou-se que 
- $\mathrm{Cr}$ foi o que mais passou para os colmos (Figura 15b), mas não atingiu um nível para se considerado pernicioso ao homem (Tabela 4)

\subsection{Efeito do Le no Estado Nutricional e no Estabelecimento da}

\section{Cultura}

A análise química de folhas, conhecida como diagnose foliar, é um método que tem sido empregado para avaliar o estado nutricional das culturas. A composição mineral da folha ou a concentração dos nutrientes que nela se encontram, é conseqüência dos efeitos dos fatores que conjuntamente atuaram até o momento em que o órgão é colhido para análise. Isolando-se o fator fertilidade do solo, a diagnose foliar consistiria, em última análise, em mais um modo para se conhecer a fertilidade do solo usando-se a planta como extratora dos nutrientes. A concentração suficiente de nutrientes para o crescimento da cultura de cana-de-açúcar, em um dado momento, reflete a integração de vários fatores: solo, clima, idade e posição do tecido no vegetal, variedade e ano de corte (cana-planta ou soqueira), o que explica existirem diversas recomendações para interpretação das análises foliares (ORLANDO FILHO et al. , 1983).

O N do solo não é analisado rotineiramente. Neste caso, pela diagnose foliar, pode-se constatar que, apesar do Le conter $N$, não teve um efeito marcante na nutrição nitrogenada. Aliás, o fato da cana-planta não responder à adubação nitrogenada não surpreende, pois isto é comum ocorrer quando do cultivo desta gramínea nos solos paulistas (ORLANDO $\left.F^{\circ}, 1993\right)$. Fato semelhante foi observado 
por MARQUES (1990), quando analisou o $\mathrm{N}$ no caldo de cana-planta cultivada onde houve adição de diferentes doses de Le.

Os demais nutrientes que tiveram seus teores no solo influenciados pela aplicação de Le, também tiveram modificados os seus teores foliares. Verificaram-se aumentos nos teores de Ca (Fig. 11c), P (Fig. 11b), Mg (Fig. 11a), S (Fig. 10a), Zn (Fig. 9a), B (Fig. 10d) e Cu (Fig. 10b).

A exemplo do que aconteceu no solo, houve diminuição no teor de $\mathrm{K}$ na folha, pela adição de Le (Fig. 11d). São duas as possíveis explicações para o fato. A primeira se deve à diminuição nǫ teor de $K$ no solo pela ação de diluição no complexo coloidal pela simples adição de Le e a segunda, devido ao antagonismo na absorção entre este e o Ca e Mg (RAIJ, 1991), os quais foram fornecidos pelo Le e liberados no solo. O balanceamento no solo destes nutrientes foi importante, pois tem efeito na produtividade da cana-de-açúcar nos solos paulistas (BEAUCLAIR, 1994).

Comportamento diferente observou-se para o Mn (Fig. 9b ) e o Fe (Fig. 10c). Neste caso, a adição de Le no solo diminui o seu teor extraído em DTPA, das amostras de terra, mas este efeito não foi verificado no teor foliar.

No caso do Fe, houve aumento no seu teor extraído do solo pelo DTPA pela aplicação de Le, mas seu teor sofreu redução nas folhas, conforme aumentou a dose deste resíduo (Figura 10c). A explicação possível é o fato do Fe se acumular nas raizes, conforme constatou DIAS (1994) para o sorgo granifero. Um outro aspecto pode estar relacionado com o antagonismo na absorção com outros nutrientes e mesmo metais pesados que tiveram seus teores aumentados no solo, devido a aplicação de Le. 


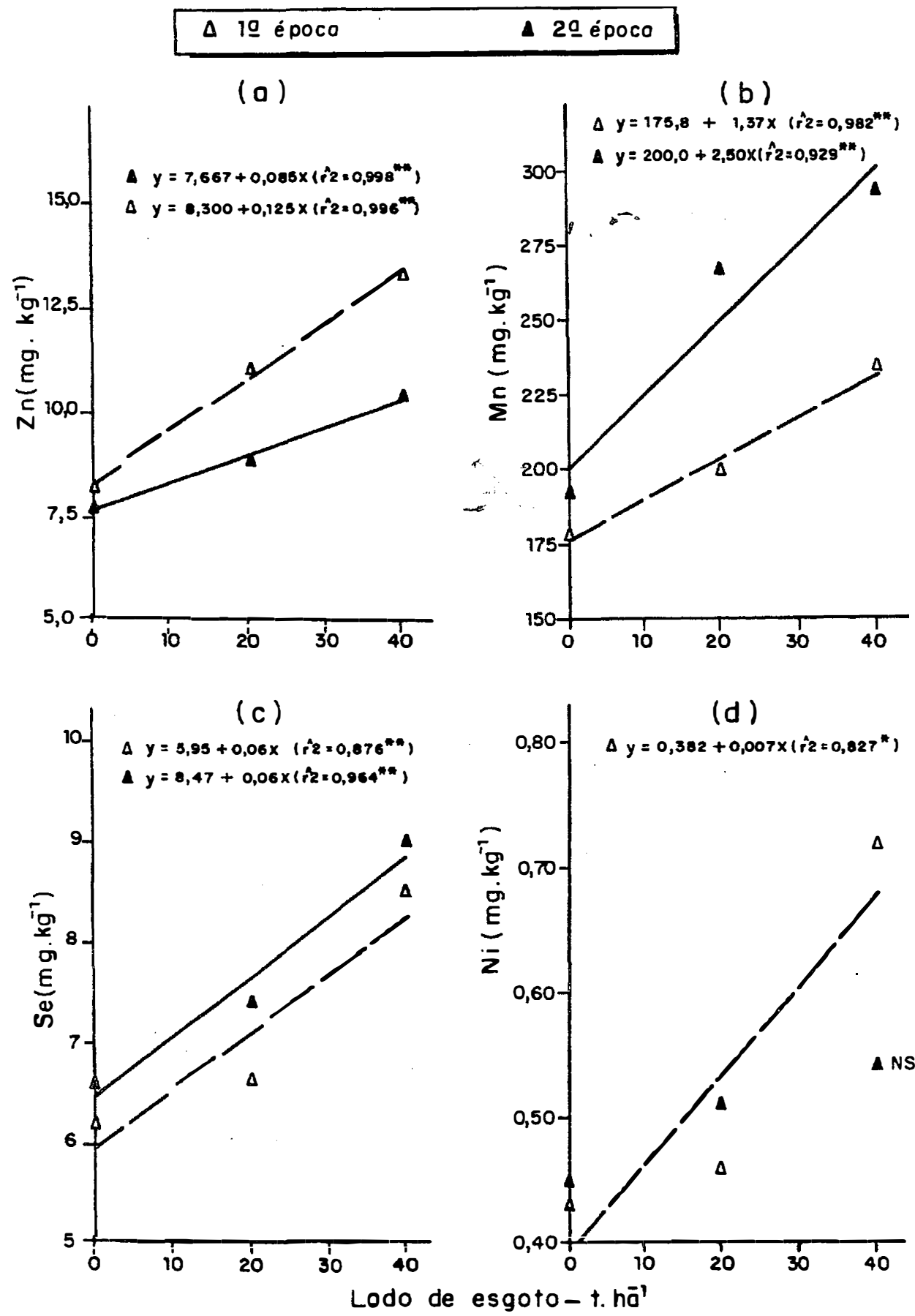

Figura 9 - Influêncio das doses de esgoto ao solo, nos conteúdos foliares de zinco (a), de manganês (b), de selênio (c) e de níquel(d) na canoplanto, aos 146 e 272 dap.

*-significativo a $5 \%$ de probabilidade, no teste $F$ **-significativo a $1 \%$ de probabilidade, no teste $F$ NS-não significativo, no teste $F$ 


\section{$\Delta$ IO époco $\Delta 29$ époco}

(a)

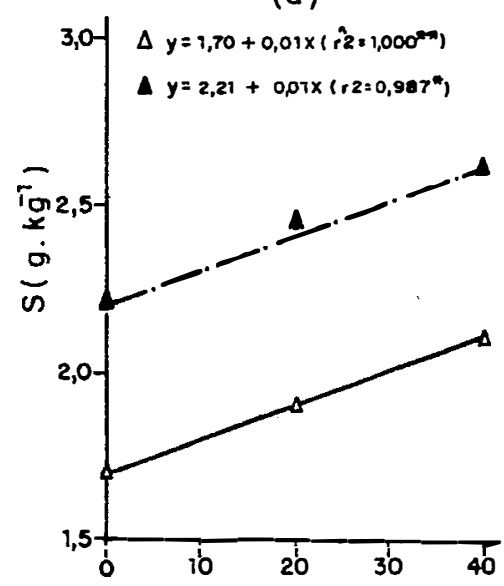

(b)

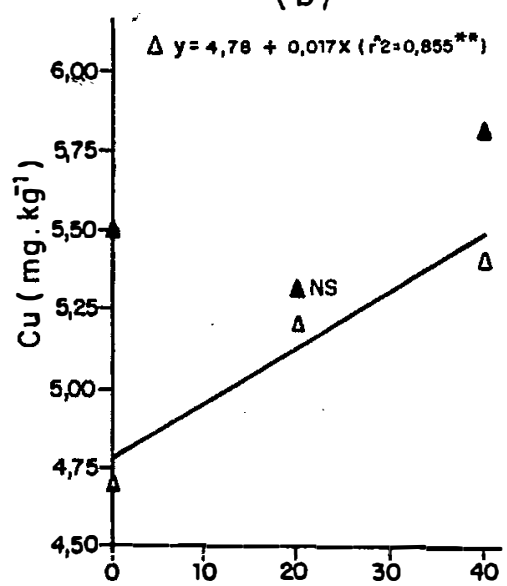

(c)

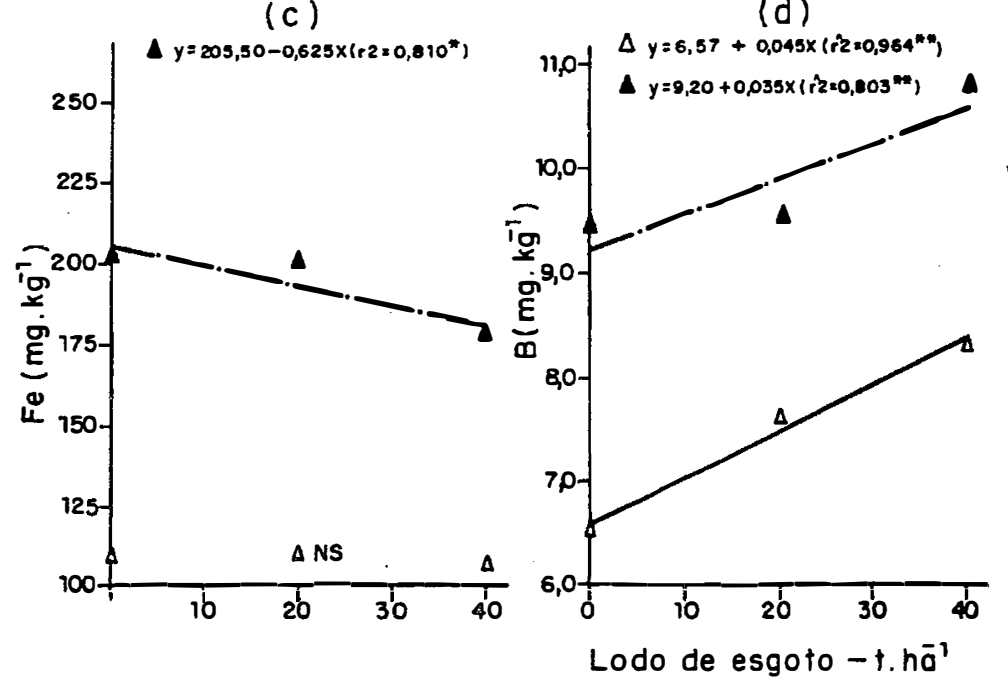

(e)

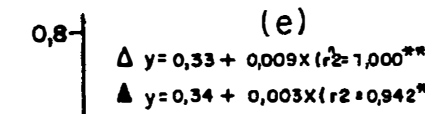

$\Delta y=0,33+0,009 \times\left(r^{2}=7,000^{* *}\right.$

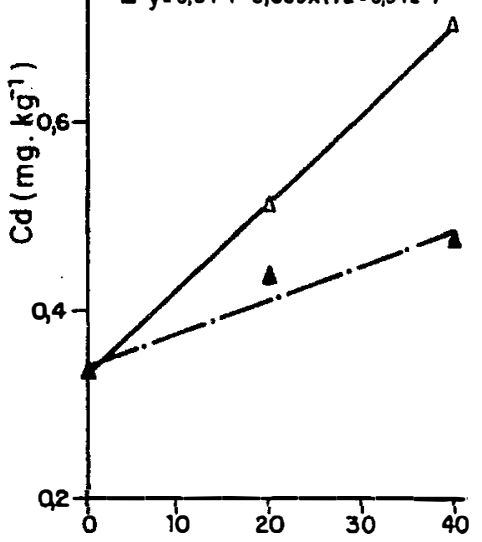

Figura 10-Influêncio dos doses de lodo de esgoto ao solo, nos conteúdos foliares de enxofre (a), de cobre(b), de ferro(c), de boro(d) e de códmio (e) no canaplanto, oos 146 e 272 dop.

* significativo a $5 \%$ de probabilidade, no teste $F$. * * significativo a $1 \%$ de probabilidade, no feste $F$. NS nōo significativo, no teste $F$. 


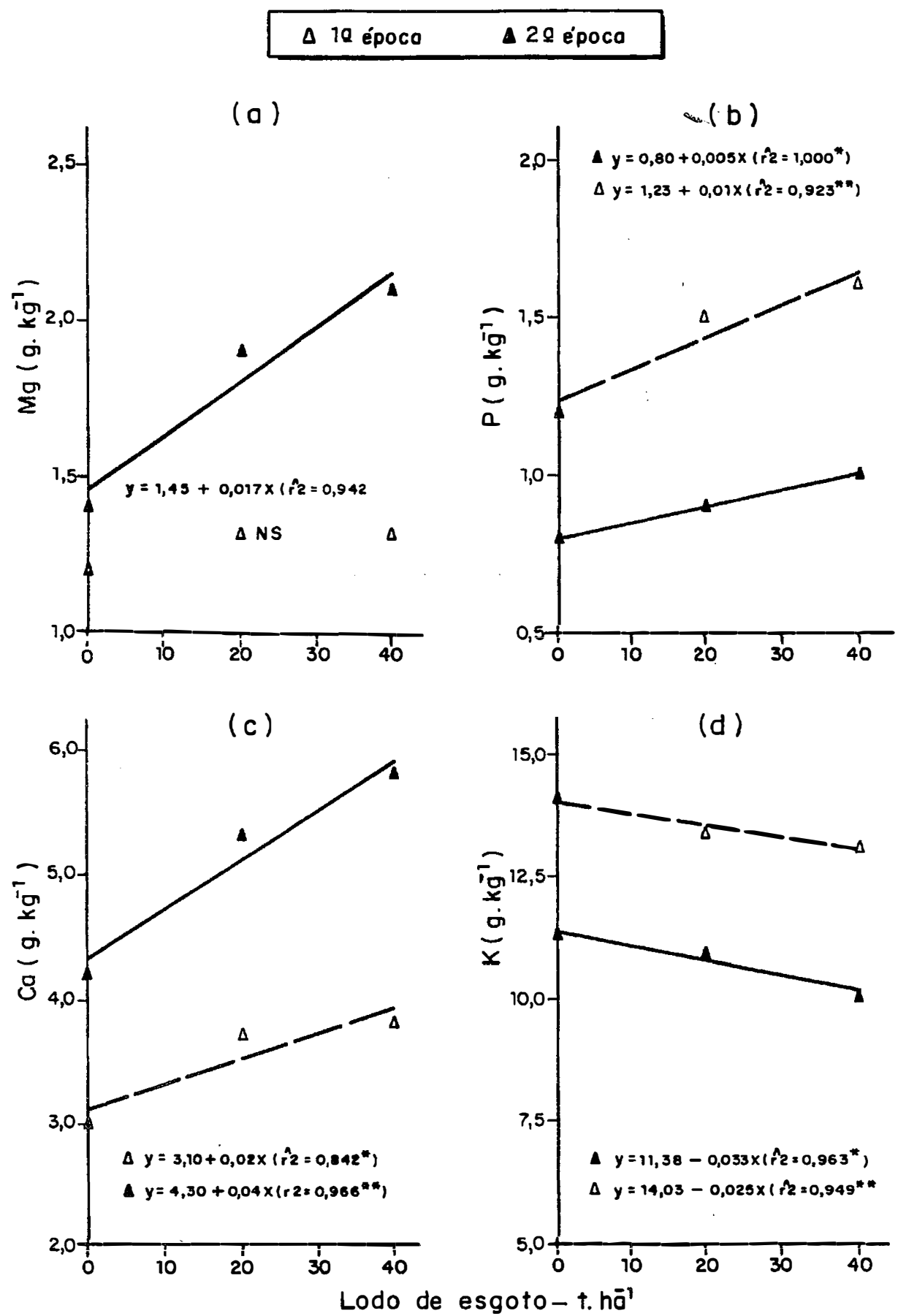

Figura 11 - Influéncia da aplicação de doses de lodo de esgoto ao solo nos conteúdos foliares de magnésio (a), de fósforo(b), de cálcio(c) e de potássio (d) no cano-planta, aos 146e 272 dap.

*-significativo o $5 \%$ de probabilidade, no teste $F$. * *-significativo a $1 \%$ de probabilidade, no teste $F$. NS-nōo significativo, no teste $F$. 
As concentrações dos nutrientes encontrados aos 146 dap nas folhas da cana-planta determinadas na testemunha e que recebeu $40{\mathrm{t} . h a^{-1}}^{\text {de Le, e os }}$ niveis críticos para "suficiência" encontrados por vários autores, dispostos entre os parênteses , são os seguintes, expressos em $\mathrm{mg} \cdot \mathrm{kg}^{-1}\left(^{\star}\right)$ e $\mathrm{g} \cdot \mathrm{kg}^{-1}$ de $\mathrm{MS}\left(^{\star \star *}\right)$ : B de 7,0 a $11,5^{\star}\left(6,0^{\star}\right.$; ORLANDO $\left.F^{\circ}, 1983\right) ;$ Ca de 3 a 5,7** $\left(4,3^{\star \star} ;\right.$ ORLANDO $F^{\circ}$ et al., 1977); Cu de 4,4 a 5,4* (4*; EL WALI \& GASCHO, 1984); Fe de 202 a $177^{*}$ (5 a 10*; EL WALI \& GASCHO, 1984); K de 14,2 a 13,0** (12 **, MALAVOLTA, 1994); Mg de 1,2 a $1,3^{\star *}\left(1,0^{\star *} ;\right.$ ORLANDO F॰, 1983); Mn de 158 a $234^{*}\left(>10^{*} ;\right.$ HUMBERT, 1968); P de 1,2 a $1,5^{\star \star}\left(1,5^{\star \star} ;\right.$ ORLANDO $\left.F^{\circ}, 1983\right) ; \mathrm{N}$ de 11,4 a $14,5^{\star \star}\left(10^{\star \star} ;\right.$ HUMBERT, 1968); S de 1,6 a $2,5^{\star \star}\left(1,3^{\star \star}\right.$; ORLANDO $F^{\circ}, 1983$ e ORLANDO $F^{\circ}$ et al ., 1977) e do Zn de 8 a $12^{*}\left(15^{\star} ;\right.$ GOLDEN, 1976).

Verifica-se que, com exceção ao $\mathrm{Ca}, \mathrm{P}$ e $\mathrm{Zn}$, todos os demais nutrientes, independente da adubação, já estariam ẹ̣ niveis na planta considerados adequados, ou seja, sem limitar a produção. $\mathrm{O}$ Ca passou de nível baixo na testemunha para alto quando foram empregadas $40 \mathrm{t}^{\mathrm{h}} \mathrm{a}^{-1}$ de Le. $\mathrm{O} P$, apesar de ter sido aumentado seu teor foliar pelo uso do Le, chegou somente no limite inferior de suficiência e finalmente, o teor de $\mathrm{Zn}$, mesmo com a adição do elemento através do Le, esteve nas duas épocas sempre abaixo do nivel de suficiência.

O estabelecimento inicial da cultura está muito associado ao seu estado nutricional; portanto, plantas que têm no solo à sua disposição quantidades adequadas de nutrientes, teriam teoricamente estado nutricional adequado, e isto possibilitaria um melhor estabelecimento inicial, refletindo no caso da cana-de-açúcar, um adequado perfilhamento. Além do aspecto de fornecimento de nutrientes do solo, 
deve-se considerar ainda a correção do complexo coloidal feita pelo Le, medido no aumento da CTC, soma e saturação por base (Tabela 5), pois isto poderia propiciar também melhores condições de estabelecimento inicial da cultura. Outro aspecto, não menos importante, a ser considerado, seria a influência do Le nas propriedades físicas do solo, pois o solo Pva empregado neste experimento tem relação textural entre os horizontes de superfície e subsuperfície arenosa/média e retém pequena quantidade de água disponível. O Le adicionado no fundo do sulco de plantio pode, além de propiciar melhor disponibilidade de água, favorecer ainda a formação de estrutura física mais adequada no solo o que, em última análise, refletiria também no perfilhamento (Fig. 12a).

A avaliação inicial do perfilhamento da cana-planta ocorreu aos 86 dap. As médias do número de perfilhos, encontradas na Figura 12a, evidenciam clara resposta à adubação com $\mathrm{P}$, seja proveniente do Le, seja da adubação química. Entretanto, verifica-se que, na ausência de Le, o perfilhamento foi incrementado pelo adubo químico, mas não foi igual quando o Le foi aplicado. Isto indicaria que o efeito do Le não se prende apenas ao aumento de disponibilidade de P no solo, mas houve também outros efeitos. Além do citado efeito do $P$, cabe ressaltar que o aumento no número de perfilhos da cana-planta (Fig.12a) pode ser explicado também pelo efeito indireto do Le na correção do complexo coloidal do solo, destacando-se a sua acidez (CTC, SB, pH e V), e o fornecimento de vários nutrientes, como Ca e Zn (Tabela 5).

De fato, nas Tabelas 5 e 6, evidencia-se que o perfilhamento é correlacionado com diversos nutrientes no solo e na folha. 
Foram feitas no campo, na mesma época da contagem de perfilhos, observações visuais da cultura. Com os dados do número de perfilhos e das observações, procedeu-se ao agrupamento dos tratamentos em três conjuntos distintos.

O primeiro grupo, de mais baixo valor de contagem de perfilhos, foi constituido pela testemunha e por aqueles tratamentos sem adição de fertilizante fosfatado. Observou-se, nas plantas cultivadas em solo que receberam estes tratamentos, uma carência muito acentuada de $P$, caracterizada pela coloração verde-azulada roxo nas folhas e pelo menor crescimento. Este fato era previsivel, haja vista que o teor original de $\mathrm{P}$ do solo extraido pela resina era de valor muito baixo, e o teor foliar, abaixo do nivel adequado, já comentado anteriormente.

No segundo grupo, encontram-se os tratamentos que receberam 20 t.ha ${ }^{-1}$ de Le. Notou-se que, quando se aplicou o Le sem suplementação de $N$, houve um ligeiro amarelecimento das folhas mais velhas, característico da deficiência de $\mathbf{N}$. Isto ocorreu possivelmente devido à imobilização do $\mathrm{N}$ nativo do solo, em fase inicial de mineralização do Le recém-adicionado.e. Todavia, essa imobilização de $\mathbf{N}$ do solo não deve ter sido muito intensa porque a relação original de $\mathrm{C}: \mathrm{N}$ do Le era inferior a 5 e no solo, aos 272 dap, encontrava-se a citada relação na ordem de 1:16.

No terceiro grupo, encontram-se os tratamentos que receberam 40 t.ha $^{-1}$ de Le, tendo sido observada nas plantas uma ligeira deficiência de $K$, que pode ter sido induzida pelo já discutido efeito antagônico deste elemento com o Ca e $\mathrm{Mg}$, que tiveram seus teores no solo elevados pelo Le. 

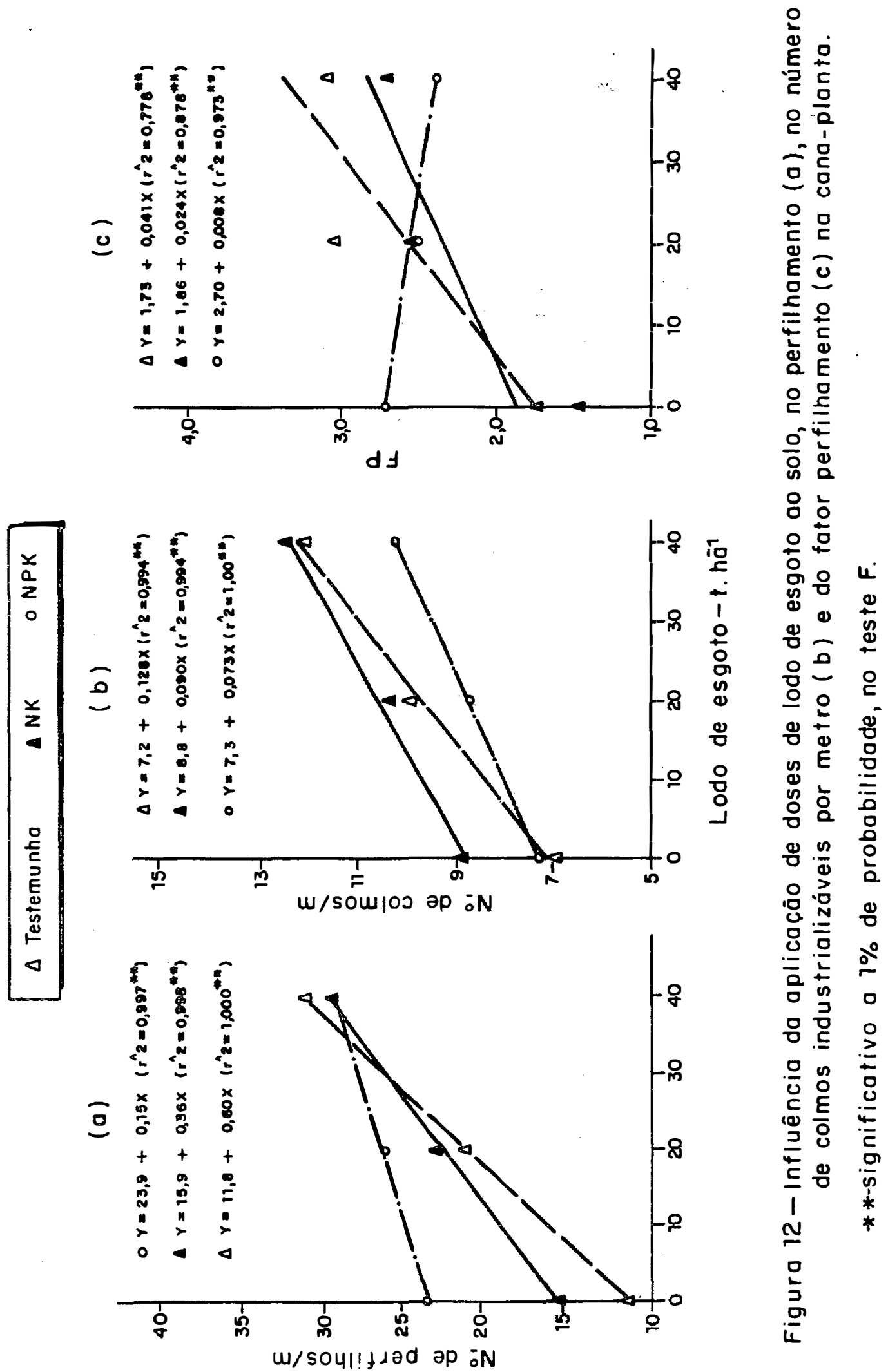
Existe relação estreita entre o perfilhamento e o número de colmos por unidade de área. Por isso, os mesmos fatores que determinam o número de perfilhos também o fazem no número de colmos . Verifica-se visualmente nas Figuras 12a e $12 b$, que são semelhantes em comportamento, embora sejam diferentes os valores da ordenada; isto porque nem todo o perfilho torna-se colmo. Quando a nutrição não é adequada, ou seja, há falta de nutriente, nem todos os perfilhos produzem colmos. Estes aspectos ficaram evidentes na Figura 12c, onde se visualiza o fator perfilhamento, que é a razão entre o número de perfilhos / número de colmos. Assim, no tratamento NPK, praticamente todos os perfilhos produziram colmos, independente da dose de Le, mas nos tratamentos em que o $P$ na forma química não foi adicionado (tratamento testemunha e NK), o fator perfilhamento foi dependente da dose de Le, evidenciando a importância do $\mathrm{P}$ no estabelecimento da cultura e no número final de colmos. Entretanto, verifica-se que o $\mathrm{P}$ não é $\mathrm{o}$ único fator que influencia $\mathrm{O}$ perfilhamento, o número de colmos por metro e o fator perfilhamento, pois estes parâmetros correlacionaram-se também com os teores foliares de $\mathrm{N}, \mathrm{P}, \mathrm{Ca}, \mathrm{Fe}, \mathrm{Zn}$, S, B e Ni na cana-de-açúcar, aos 272 dap (Tabela 6), condicionados pela simples presença dos nutrientes na constituição química do Le. Há, entretanto, outros fatores do solo relacionados à neutralização da acidez do solo que também têm influência no estabelecimento da cultura (Tabela 7).

No tocante aos efeitos de época e da interação época $x$ Le foram significativas $\left(F^{\star \star}\right)$, alterando as concentrações foliares de $\mathrm{B}, \mathrm{Ca}, \mathrm{Mn}, \mathrm{P}, \mathrm{Pb}, \mathrm{S}, \mathrm{Se}$, $\mathrm{N}$ e Zn, o que possibilita interpretarem-se os dados em uma única época. Observando-se os teores dos elementos nas folhas amostradas aos 272 dap e aos 
146 dap, salienta-se que os conteúdos de P (Fig.11b), K (Fig.11d), S (Fig.10a), B (Fig.10d) e Zn (Fig. 9a) reduziram -se nos valores de concentração entre as amostragens, concordando com os resultados de ORLANDO $F^{\circ}$ \& HAAG (1979). 
Tabela 5. Valor de correlação entre os perfilhos $/ \mathrm{m}$, colmos $/ \mathrm{m}$ e o fator perfilhamento (FP) com teores de algumas espécies químicas no solo, amostrados aos 272 dap.

\begin{tabular}{|c|c|}
\hline $\begin{array}{l}\text { Parâmetro de } \\
\text { Planta }\end{array}$ & Variáveis de solo correlacionadas ( $r$ ) \\
\hline $\begin{array}{l}\text { número de } \\
\text { perfilhos/m }\end{array}$ & $\begin{array}{c}\text { Indiretamente: } \mathrm{pH}\left(0,75^{\star \star}\right), \mathrm{H}+\mathrm{Al}\left(-0,74^{\star \star}\right), \mathrm{SB}\left(\left(0,78^{\star \star}\right), \mathrm{CTC}\right. \\
\left(0,74^{\star \star}\right) \text { e V\% }\left(0,87^{\star \star}\right) \text {. Diretamente : } \mathrm{Ca}\left(\left(0,60^{\star \star}\right), \mathrm{Mg}\left(0,65^{\star \star}\right), \mathrm{P}\right. \\
\left(0,81^{\star \star}\right), \mathrm{Cu}\left(0,69^{\star}\right), \mathrm{Zn}\left(\left(0,74^{\star \star}\right), \mathrm{Ni}\left(0,68^{\star}\right) \text { e } \mathrm{B}\left(0,54^{\star}\right),\right.\end{array}$ \\
\hline $\begin{array}{l}\text { número de } \\
\text { colmos/m }\end{array}$ & $\begin{array}{c}\text { Indiretamente: } \mathrm{pH}\left(0,73^{\star \star}\right), \mathrm{H}+\mathrm{Al}\left(-0,68^{\star}\right), \mathrm{SB}\left(\left(0,74^{\star \star}\right), \mathrm{CTC}\right. \\
\left(0,76^{\star \star}\right) \text { e V\% }\left(0,80^{\star \star}\right) . \text { Diretamente: } \mathrm{Ca}\left(0,63^{\star}\right), \mathrm{P}\left(0,75^{\star \star}\right), \mathrm{Cu} \\
\left(0,64^{\star \star}\right), \mathrm{Fe}\left(0,54^{\star}\right), \mathrm{Zn}\left(0,68^{\star \star}\right), \mathrm{Ni}\left(0,69^{\star \star}\right) \text { e B }\left(0,65^{\star \star}\right) .\end{array}$ \\
\hline Fator Perfilha- & Indiretamente: $\mathrm{pH}\left(0,74^{\star \star}\right), \mathrm{H}+\mathrm{Al}\left(-0,76^{\star \star}\right)$, SB $\left(0,75^{\star \star}\right)$, СТC \\
\hline $\begin{array}{l}\text { mento (n. } \\
\text { perf./n.c.) }\end{array}$ & $\begin{array}{l}\left(0,70^{\star \star}\right) \text { e V\% }\left(0,84^{\star \star}\right) . \quad \text { Diretamente: } \mathrm{Ca}\left(0,56^{\star \star}\right), \mathrm{Mg}\left(0,66^{\star}\right), \mathrm{P} \\
\left(0,80^{\star \star}\right), \mathrm{Cu}\left(0,66^{\star \star}\right), \mathrm{Fe}\left(0,50^{\star}\right), \mathrm{Zn}\left(0,73^{\star \star}\right), \mathrm{Ni}\left(0,66^{\star \star}\right), \mathrm{B}\left(0,49^{\star}\right),\end{array}$ \\
\hline
\end{tabular}

${ }^{*} \mathrm{e}^{\star \star}=$ significativos a 5 e $1 \%$ no teste $\mathrm{F}$ 
Tabela 6. Valor de correlação entre os perfilhos $/ m$, colmos $/ m$ e o fator perfilhamento(FP) com teores de algumas espécies químicas nas folhas +3 , amostradas aos 272 dap.

\begin{tabular}{cl}
\hline Parâmetro Fitotécnico & Espécies químicas na folha +3 relacionadas(r) \\
\hline número de perfilhos/m & $\mathrm{N}\left(0,74^{\star \star}\right), \mathrm{P}\left(0,78^{\star \star}\right), \mathrm{Ca}\left(0,79^{\star \star}\right), \mathrm{Fe}\left(-0,61^{\star}\right)$, \\
& $\mathrm{Mn}\left(0,65^{\star}\right), \mathrm{Zn}\left(0,47^{\star}\right), \mathrm{Ni}\left(0,65^{\star \star}\right), \mathrm{B}\left(0,61^{\star \star}\right)$ e \\
& $\mathrm{Al}\left(-0,60^{\star}\right)$ \\
número de colmos/m & $\mathrm{P}\left(0,52^{\star \star}\right), \mathrm{Ca}\left(0,66^{\star \star}\right), \mathrm{Fe}\left(0,62^{\star}\right), \mathrm{Mn}\left(0,72^{\star \star}\right)$, \\
$\mathrm{Ni}\left(0,59^{\star \star}\right), \mathrm{B}\left(0,52^{\star}\right), \mathrm{S}\left(0,70^{\star \star}\right)$ e Al $\left(-0,74^{\star \star}\right)$ \\
Fator Perfilhamento $\left(n^{\circ} \quad \mathrm{N}\left(0,73^{\star \star}\right), \mathrm{P}\left(0,79^{\star \star}\right), \mathrm{Ca}\left(0,77^{\star \star}\right), \mathrm{Fe}\left(-0,63^{\star}\right)\right.$, \\
perf./n.c.)
\end{tabular}

${ }^{*} e^{* *}=$ significativos a $5 \%$ e $1 \%$, no teste $F$ 


\subsection{Efeitos do Le nas Produtividades, nas Características Tecnológicas e na Composição Química da Cana-de-Açúcar}

Nas Figuras 13b, 13c e 13d encontram-se as produtividades em biomassa fresca e de açúcar (pol e açúcar teórico recuperável) nos colmos da canaplanta. Verificou-se, pela análise estatística, os efeitos da adição de Le $\left(F^{\star \star}\right)$, da complementação química NPK $\left(F^{\star \star}\right)$ e a interação Le $x$ adubação $\left(F^{\star \star}\right)$ naqueles parâmetros. Sabe-se que a produtividade agrícola de uma cultura qualquer é dependente das condições ambientais, das caracteristicas físicas e da fertilidade do solo. No caso do presente experimento, constatou-se que houve deficiência hídrica (item 4.1.), mas mesmo assim a menor produtividade obtida foi ao redor de 130 t.ha $^{-1}$ de colmos frescos (Figura 13b), acima da média do Estado de São Paulo.

Com referência ao efeito do Le, devem-se destacar os aspectos ligados à fertilidade do solo e à nutrição vegetal. Antes de iniciar os comentários a respeito dos mesmos, contudo, é necessário lembrar que no trabalho presente não se isolam os fatores, e eles não são independentes. Por exemplo, pela adição de Le altera-se o complexo coloidal, mas adicionam-se simultaneamente $\mathrm{P}, \mathrm{Ca}$, micronutrientes, entre outros. Separar então os fatores determinantes dos aumentos de produtividade é tarefa difícil neste caso; portanto, sempre devem ser vistos com certa reserva os comentários que se seguem.

O primeiro aspecto se refere ao fato do Le, quando aplicado isoladamente, aumentar linearmente as produtividades dos colmos frescos e de açúcar (Figuras 13c e 13d), verifica-se que a dose de 40 t.ha $^{-1}$ de Le possibilitou 
produtividades de colmos e de açúcar próximas das produtividades obtidas no tratamento NP (sem Le). Esta correspondência entre estes tratamentos se deve ao fato que o Le forneceu $\mathrm{P}$ ao solo, originalmente deficiente nesse elemento, possibilitando uma nutrição fosfatada mais adequada da cana-de-açúcar.

Constata-se que nem a análise do solo, nem a análise de tecido vegetal foram técnicas adequadas para demonstrar a importância da adubação fosfatada, pois não houve correlação entre os teores de $\mathrm{P}$ extraídos pela resina do solo(Tabela 7) e os teores foliares no elemento (Tabela 8) com a produtividade de colmos despontados. Entretanto, foram observadas correlações positivas entre as produtividades de pol e de açúcar recuperável e os teores de $\mathrm{P}$ no solo e nas folhas, o que talvez seja explicado pelo fato do elemento citado ser um nutriente importante no metabolismo energético da planta. Este é um processo dependente da atividade da fosfatase ácida, estando inversamente relacionado à produção de MS pela planta (SILVA \& BASSO, 1993). Em última análise, o referido procesșo está correlacionado ao balanço secundário das fosfatases pelo conjunto dos metais $\mathrm{Cu}, \mathrm{Zn}$ e $\mathrm{B}$ como observado por BESFORD (1979), não sendo, portanto, o P, o único elemento responsável pelo aumento de produtividade dos colmos através da incorporação de compostos carbônicos. Entretanto, sabe-se que a adubação fosfatada tem sido um fator importante para o aumento da produtividade da cana-de-açúcar no Estado de São Paulo, como está amplamente demonstrado na literatura (MALAVOLTA et al., 1963; FREIRE et al. ,1968 e SERRA, 1973). 


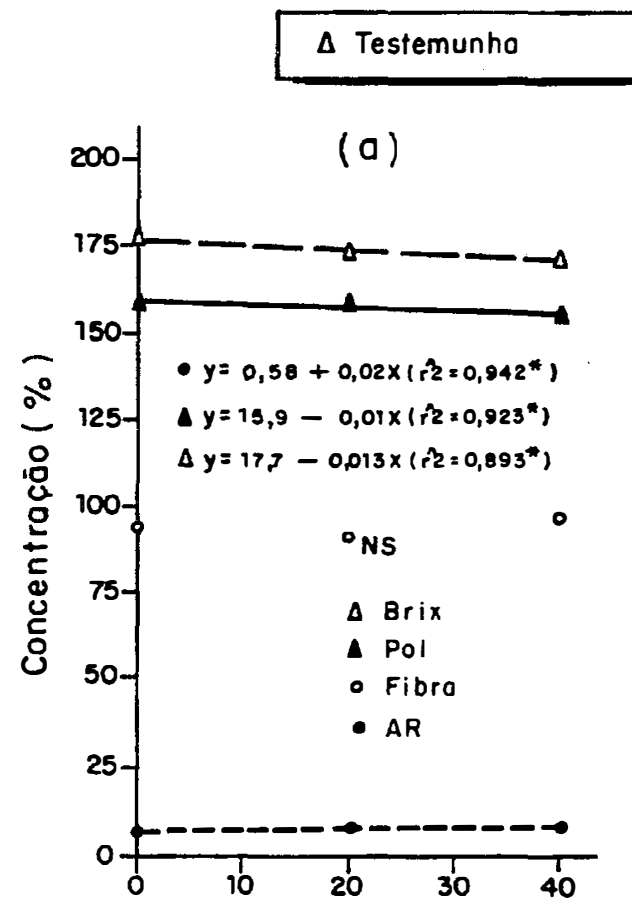

$\triangle N K$

o NPK
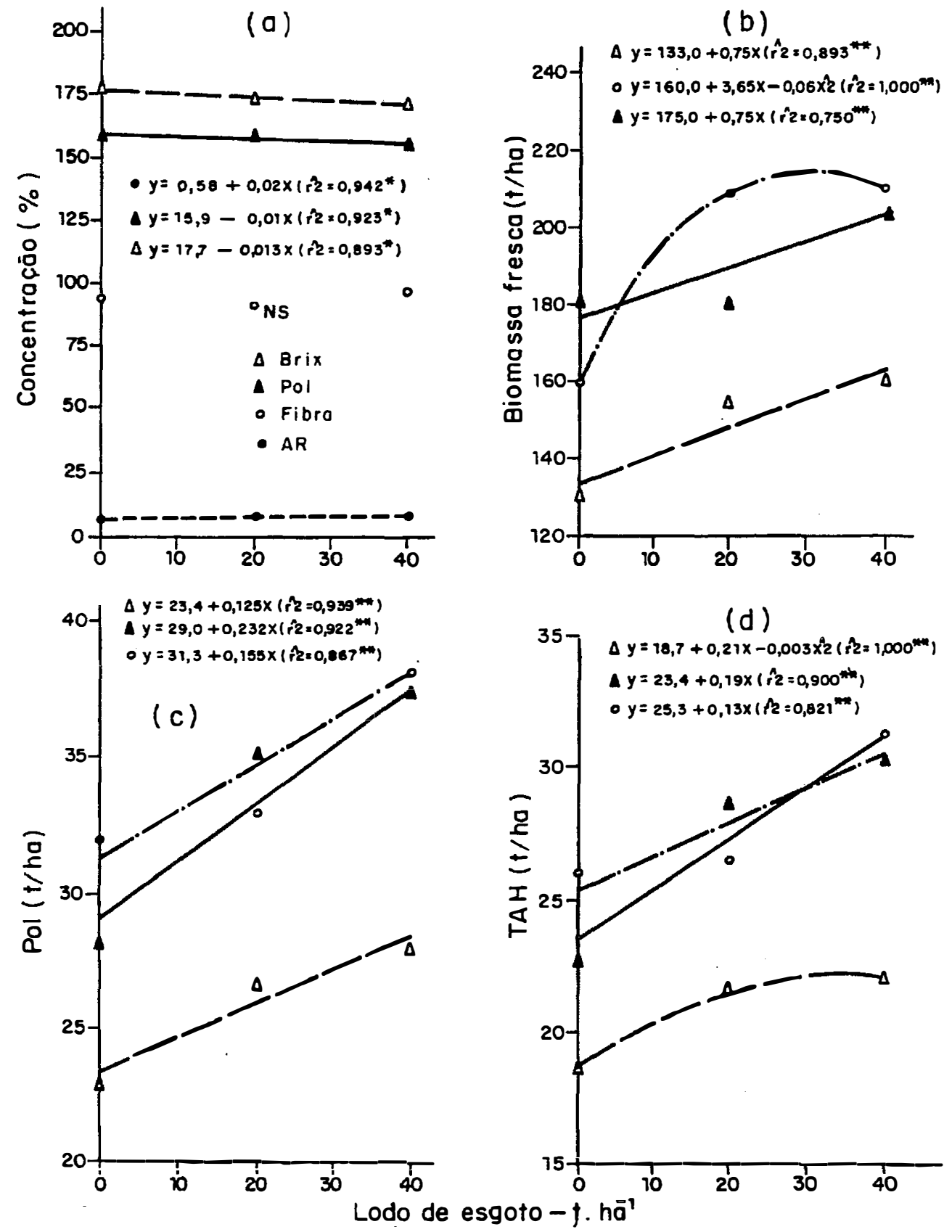

Figura 13-Influencio do oplicąāo de doses de lodo de esgoto ao solo nos características tecnológicas (a), produtividades de biomassa(b), de sacarose aparente (c) e de açúcar teórico recuperável (d), nos colmos de cana-planta, aos 469 dap.

*-significativo a $5 \%$ de probabilidade, no teste $F$. * *-significativo a $1 \%$ de probabilidade, no teste $F$. 
No caso do N, apesar do Le conte-lo e fornecer ao solo $334 \mathrm{~kg}^{-h a^{-1}}$ na dose de 40 t.ha $^{-1}$, não deve ter sido um dos nutrientes causadores dos aumentos da produtividade dos colmos despontados, de pol e de açúcar recuperável, pois em todos os tratamentos o seu teor foliar sempre esteve acima do teor adequado. Também ficou evidenciado este fato pela não existência de correlação entre as variáveis citadas. Reafirma-se ainda que não é freqüente haver resposta da canaplanta à adubação nitrogenada (ORLANDO $\mathrm{F}^{\circ}$ \& ZAMBELLO JR, 1980 e ORLANDO F 1983).

Um terceiro aspecto se refere à adubação potássica. Apesar do solo originalmente ter teor muito baixo de $\mathrm{K}$, podendo-se esperar, portanto, resposta da cana-de-açúcar à adubação com este nutriente, os resultados de produtividades, à primeira vista, não evidenciaram este aspecto. Primeiramente cabe ressaltar que o teor foliar de $\mathrm{K}$ em todos os tratamentos esteve dentro da faixa adequada, indicando que o solo supriu adequadamente a exigência nutricional de cana-de-açúcar deste nutriente.

Na Figura 13b pode-se constatar certa tendência de aumento da biomassa fresca de colmos despontados, devido ao $\mathrm{K}$, quando se comparam os tratamentos NP e NPK, ambos em presença de 20 t.ha $^{-1}$ de Le. Ë necessário ressaltar que o $\mathrm{K}$ tem sido um nutriente de grande importância no aumento da produtividade da cana-de-açúcar no Estado de São Paulo, como demonstra a ampla literatura sobre o assunto (ORLANDO Fo, 1983; RAIJ et al, 1987). Esta importância se deve ao fato de que o $\mathrm{K}$ participa de vários processos bioquímicos associados ao sistema aquoso, dos quais depende o ganho de produtividade em biomassa de colmos 
(ALEXANDER, 1973; BEALFILS, 1973). Os resultados das Tabelas 7 e 8, no que diz respeito ao $\mathrm{K}$ parecem ser contraditórios tendo em vista que mostram correlação negativa entre as produtividades e os teores foliares e por outro lado, apresentam positiva entre a mesma produtividade e o teor de $\mathrm{K}$ no solo. Este último aspecto não causa nenhuma preocupação, pois é sabido que o $\mathrm{K}$ tem fundamental importância no metabolismo e no transporte de carboidratos. Para a obtenção desta correlação foram empregados todos os resultados de teores foliares. É de se esperar que a adubação química potássica recomendada no Estado de São Paulo tenha propiciado um suprimento deste nutriente à cultura (RAIJ et al., 1985), elevando o teor foliar e assim, aumentando a produtividade, motivando correlações positivas entre as duas variáveis. 0 que se acabou de dizer, em nada contradiz o fato de que na presença de Le há diminuição no teor foliar de K (Figura 11d), como comentado anteriormente, pois estes valores são apenas as médias foram consideradas no referido cálculo. O aspecto que causa surpresa é o fato de haver correlação negativa entre os teores de $\mathrm{K}$ no solo e as produtividades da cana-de-açúcar (Tabela 7), o que é um absurdo, pois o teor inicial de K no solo era muito baixo. O que deve ter acontecido é que a diminuição de $\mathrm{K}$ no solo é, neste caso, uma variável dependente, ou seja, houve decréscimo do seu teor no solo devido ao uso de Le, que aumentou a produtividade. Destaque-se que o teor de $\mathrm{K}$ no solo que foi amostrado na projeção do sulco de plantio refletiu essencialmente a atuação do Le ali localizado, pois a maior parte do $\mathrm{K}$ na forma de fertilizante químico foi aplicado aos 30 e 45 dap, em cobertura, o que levou à pouca participação do adubo potássico na análise das terras, na camada de $0-20 \mathrm{~cm}$. Porém, a fertilização química potássica aumentou significativamente o teor deste elemento nas folhas do vegetal. Tendo em vista 
o exposto, a correlação entre o K no solo amostrado na projeção do sulco de plantio e a produtividade, não pode ser levada em consideração. Diante do que se comentou fica evidente a necessidade de se fazer a complementação do Le em K para se obter altas produtividades em solos de baixa fertilidade natural e pobre em $\mathrm{K}$.

Um outro aspecto a se considerar é o efeito do Le na correção do complexo coloidal do solo, favorecendo assim a produtividade da cana-de-açúcar. Como as variações nos teores de $\mathrm{Ca}, \mathrm{H}+\mathrm{Al}$ e o $\mathrm{pH}$ variaram concomitantemente, as correlações destes com as produtividades (Tabela 7) devem ser vistas com cautela, principalmente pelo fato de não ter havido teores foliares que estavam abaixo e acima do nível considerado suficiente (item 4.5.). Todavia, saliente-se que a correlação entre teores de Ca no solo e as produtividades da cana-de-açúcar foram positivos (Tabela 7). Neste sentido, pode se dizer que o Le pode substituir a calagem quanto ao seu aspecto de efeito corretivo do complexo coloidal do solo, o que reverte em aumento da produtividade. Há trabalhos na literatura demonstrando que a cana-de-açúcar necessita de teores adequados de $\mathrm{Ca}+\mathrm{Mg}$ no solo, devendo-se recomendar a calagem quando este for menor que $19 \mathrm{mmol}_{d} \mathrm{dm}^{3}$ de terra (ORLANDO $\left.\mathrm{F}^{\circ}, 1983\right)$. Considerando-se a saturação em bases de $60 \%$ como ideal para a cana-de-açúcar , poder-se-ia dizer que a aplicação de 20 t.ha $^{-1}$ de Le, no caso do solo com CTC originalmente baixa, como é o caso presente, seria suficiente para se corrigir o complexo coloidal nas proximidades do sulco de plantio. Verificou-se entretanto, que este efeito é de curta duração, ou seja, se restringiria a apenas 1 ano agrícola (MARQUES, 1990), exigindo-se pois nova aplicação do resíduo na cana-soca. 
Os aspectos relacionados aos fornecimentos pelo Le de $\mathrm{Mg}$, S e micronutrientes e seus efeitos sobre as produtividades da cana-de-açúcar, quando cada um deles é considerado isoladamente, são difíceis de serem comentados, por variarem conjuntamente, já que o Le os contêm. No caso presente, pela análise foliar, constatouse que o Mg, S, B, Cu, $\mathrm{Fe}, \mathrm{Mn}$ estiveram sempre em níveis adequados neste tecido e, portanto, teoricamente, não deveriam influenciar a produtividade. Somente o $\mathrm{Zn}$, que permaneceu sempre abaixo do nível adequado, estaria limitando a produtividade, daí considerar-se correta a correlação positiva entre os teores foliares deste micronutriente e a produtividade da cana-de-açúcar ( Tabela 8). Na literatura nacional, os resultados sobre $\mathrm{S}, \mathrm{Mg}$ e micronutrientes indicam que as respostas da cana-de-açúcar não são freqüentes (ORLANDO $F^{\circ}$, 1983), porém ressalve-se os ensaios realizados em solos tabuleiros na Bahia e em Alagoas para estudos com micronutrientes, e algumas pesquisas com o uso do gesso agrícola, fonte de $\mathrm{S}$ aplicado em latossois.

$\mathrm{Na}$ tentativa de se dar uma interpretação mais holística dos fatores de solo e da planta relacionados com a produtividade econômica, medida pelas quantidades de sacarose aparente (pol) e açúcar teórico recuperável na indústria (ATR) por unidade de área, aplicou-se a metodologia proposta por MALLOWS (1975). Por este processamento matemático foram selecionados os parâmetros de solo e teores foliares mais importantes que condicionaram a produtividade econômica, com probabilidade mínima de $5 \%$ no Teste $\mathrm{F}$, através do procedimento teste de todas as possiveis regressões pelo Coeficiente Padrão (Cp). O Cp de Mallöws é calculado para todas as possiveis combinações de parâmetros de solo ou de planta em diversas regressões e, segundo o autor, o melhor modelo é aquele onde a diferença entre tal coeficiente e o 
número de parâmetros $(p)$ for mínimo, cujos resultados se encontram nos Apêndices 8 a 13.

Saliente-se que a produtividade em açúcar, de forma semelhante ao que ocorreu com a produtividade de biomassa, foi condicionada pela ação indireta do Le como corretivo da acidez do solo (Apêndice 8), e fornecendo Ca, Mg, P, S, $\mathrm{Cu}, \mathrm{Zn}$ e $\mathrm{B}$, o que refletiu no aumento de absorção pela cana destes nutrientes. As alterações de produtividade econômica da cana-de-açúcar foram em $90 \%$ explicadas por modelo multivariado linear usando os teores foliares de $\mathrm{Ca}, \mathrm{Mg}, \mathrm{P}, \mathrm{S}$, $\mathrm{Cu}, \mathrm{Zn}$ e B como variáveis preditoras, provavelmente ocorreu uma ação de conjunto dos nutrientes (Apêndice 9). Estes resultados introduzem dois outros nutrientes que haviam sido considerados quando da análise individual dos nutrientes e seus efeitos sobre as produtividades, ou sejam, o Cu e o B. Entretanto, como já apresentado, sabe-se da relação secundária que estes dois micronutrientes e o $\mathrm{Zn}$ têm sobre a atividade da fosfatase ácida e o adequado suprimento de P (BESFORD, 1979), podendo em última análise refletir em aumento de produtividades da cana-deaçúcar.

Quanto ao efeito do Le nas características tecnológicas da cana-deaçúcar, pode-se constatar pela Figura 13a, que não foram afetados pela adubação com Le : Brix, pol, fibra e açúcares redutores, pois as variações destes parâmetros tecnológicos foram pequenos. Este aspecto resultou em estreita faixa de variação na quantidade de ATR, de 124 a $128 \mathrm{~kg}$ de açúcar recuperável por tonelada de biomassa. Pequena redução do teor de açúcar nos colmos, devido a adubação com Le, foi verificada por MARQUES et al.(1994), resultando em redução de $6 \%$ da 
valorização da matéria prima quando a dose de 32 t.ha $^{-1}$ de Le foi aplicada, em comparação à testemunha (adubação comercial).

Finalmente, é necessário enfatizar que estes aspectos comentados abrangem todos os efeitos benéficos do Le sobre as produtividades da cana-deaçúcar no presente ensaio. Neste sentido, a própria análise estatística já havia demonstrado que existe interação entre o Le e a adubação química, o que fica evidente nas Figuras 13b, c e d.

Além das análises tecnológicas dos colmos, pode-se analisar alguns outros aspectos ligados ao caldo. Assim, verificou-se que para o caldo houve ainda um aumento linear na relação $A R /$ cinzas pela adição do $L e\left(F^{\star \star}\right)$, que passou de 1,95 (Testemunha) para 2,2 (20 t.ha $\left.{ }^{-1}\right)$ e 2,6 (40 t.ha $\left.{ }^{-1}\right)$, o que proporcionaria leve tendência ao maior esgotamento do melaço (HONIG, 1968).

Os coeficientes de variação do Brix, pol, fibra e AR da cana, ATR, TCH, Tpol/ha, TAH e $\mathrm{P}_{2} \mathrm{O}_{5}$ foram de 1,$8 ; 1,9 ; 5,1 ; 7,0 ; 2,7 ; 11,9 ; 10,7 ; 9,8$ e $5,4 \%$, respectivamente, considerados baixos para fins agrícolas ( GOMES, 1985).

O P presente no caldo é muito importante para a adequada clarificação deste na produção do açúcar branco. Neste aspécto determinou-se que o Le provocou decréscimo no teor de $\mathrm{P}_{2} \mathrm{O}_{5}$ inorgânico no caldo, obtendo-se entre estes dois tratamentos correlação negativa $\left(Y=486,0-1,12 . X ; r^{2}=91,00^{\star \star}\right.$, onde $Y=m g$ $\cdot \mathrm{P}_{2} \mathrm{O}_{5} / \mathrm{L}$ e $\mathrm{X}=$ t.ha ${ }^{-1}$ de Le). Os teores de $\mathrm{P}_{2} \mathrm{O}_{5}$ do caldo, que variaram na faixa de 486 a $441 \mathrm{mg} / \mathrm{L}$, estão acima das necessidades exigidas na fermentação para a produção do álcool (AMORIM, 1985) e na clarificação para o açúcar branco (HONIG, 1969). 
Quanto à composição química observada na análise dos colmos, verificou-se que houve efeito da aplicação de Le ao solo $\left(F^{\star \star}\right)$ na concentração de $\mathrm{Cu}$, Mn, N, P e S (Apêndice 7). Quando se compararam os nutrientes que variaram significativamente nos colmos, através dos dados obtidos nos tratamentos testemunha e com a adubação de Le na dose de 40 thha $^{-1}$, verificaram-se variações nos teores destes, como seguem : $\mathrm{Cu}\left(6,8\right.$ a $\left.8,6^{\star}\right), \mathrm{Mn}\left(35\right.$ a $\left.32^{\star}\right), \mathrm{N}\left(2,2\right.$ a $\left.2,5^{\star \star}\right), \mathrm{P}($ 0,4 a $\left.0,5^{\star \star}\right)$ e $S\left(0,65\right.$ a $\left.0,93^{*}\right)$, onde expressou-se em mg.kg- $1\left(^{*}\right)$ e g/kg( $\left(^{* *}\right)$ de MS, respectivamente. Não houve efeito da adição de Le na concentração de $\mathrm{Al}, \mathrm{B}, \mathrm{Ca}$, $\mathrm{Fe}, \mathrm{K}, \mathrm{Mn}$, sódio, $\mathrm{Pb}$ e $\mathrm{Zn}$ nos colmos ( $\mathrm{F}=\mathrm{NS})$. Houve ainda efeito da adubação quimica complementar no teor de $\mathrm{N}$ e não dos outros elementos dos colmos ( $\mathrm{F}=\mathrm{NS}$ ).

Considerando-se agora as diferenças percentuais nas concentrações dos nutrientes que foram significativos para o efeito do Le, através dos dados da testemunha e da maior dose de Le, verificou-se que houve um aumento na ordem de 20 a $30 \%$, o que deve proporcionar ganhos semelhantes no caldo destas canas. Os aumentos de 20 a $30 \%$ nas concentrações de $\mathrm{Cu}, \mathrm{Mn}, \mathrm{N}, \mathrm{P}$ e S no caldo, mesmo que esses elementos porventura nele permanecessem até a obtenção da massa cozida, onde poderiam atuar como substância melassigênica, teoricamente, mas na prática não teriam qualquer problema durante as fases finais do processo da fabricação do açúcar, porque a interferência na formação do melaço é principalmente física e governada pelo aumento de viscosidade da massa cozida, que depende essencialmente dos teores de gomas ali presentes (CESAR et al, 1989). Outrossim, observe-se que a estimativa da quantidade de açúcar dito recuperável na indústria por tonelada de cana não foi alterado pela adição de Le $(F=N S)$, conforme 
valor calculado pela fórmula de recuperação teórica do açúcar proposta pela COPERSUCAR.

Um outro aspecto relacionado com a produção do álcool é o teor de nutrientes e metais pesados no caldo. Os teores de N, P, S, K, Ca e Mg não foram analisados nos caldos, mas podem ser estimados levando-se em consideração os teores dos mesmos nos colmos. Neste sentido, DELGADO \& CESAR (1977) apresentam a porcentagem dos nutrientes que passam para o caldo no processo de extração, ou seja, de 75 a $85 \%$ de N, P e S, de 90 a $95 \%$ do K, de 75 a $85 \%$ do $\mathrm{Ca}$, de 85 a $90 \%$ do $\mathrm{Mg}$ e o $\mathrm{Cr}, \mathrm{Cu}, \mathrm{Mn}$, Ni e Se que não se encontram dados na literatura a respeito da passagem dos colmos para o caldo, mas, para fins de estimativa, considerou-se como sendo $75 \%$.

Os teores estimados de nutrientes no caldo $\left(\mathrm{mg}^{-\mathrm{L}^{-1}}\right)$ obtidos dos tratamentos sem e com 40 t.ha $^{-1}$ de Le, são comparados a seguir com os teores ideais no mosto para fins de fermentação alcoólica, ou seja, o caldo diluído com aproximadamente 30 \% de água que recebe do processo de embebição da cana durante a moagem. $O$ primeiro valor se refere ao teor no caldo do tratamento testemunha (sem Le), o segundo do tratamento que recebeu 40 t.ha $^{-1}$ do resíduo e o número entre parênteses se refere ao dado da literatura, acrescido em $30 \%$ (AMORIM, 1985), nos teores dados em mg/L: $N$ de 1870 a $2120 \mathrm{mg}$ (650 a 780) ; P de 450 a $510 \mathrm{mg}(70$ a 130); $K$ de 1900 a $1700 \mathrm{mg}$ (910 a 1560); Mg de 400 a 520 $\mathrm{mg}$ (260); Mn de 28 a $23 \mathrm{mg}(2,5)$ e Zn de 8 a 11 (2,5). Estes teores de nutrientes estimados no caldo estariam confirmando a boa qualidade da matéria prima a produção do álcool. 
No caso dos metais pesados $\mathrm{B}, \mathrm{Ni}, \mathrm{Cr}$ e Se que tiveram seus valores alterados no colmo devido à adubação com Le, em relação à testemunha teriam, portanto, seus teores estimados também influenciados no caldo, chegando-se a suposição de que esses aumentos não causariam prejuizos ao processo de fermentação alcoólica. Os valores estimados $\left(\mathrm{mg}^{\mathrm{L}} \mathrm{L}^{-1}\right)$ no caldo da testemunha e do tratamento com 40 t.ha $^{-1}$ de Le que são, respectivamente: B de 6 e 8 (79), Ni de 0,24 e 0,54(105), $\mathrm{Cr}$ de 0,18 a 0,38 (168) e Se de 2 a 3,2 (520), estão muito aquém dos limites máximos que reduziriam em $50 \%$ o crescimento da leveduras (WHITE,1954), cujos valores estão dispostos entre os parênteses. 
Tabela 7. Valor de correlação entre as produtividades da cana-planta, expressa em colmos despontados colhidos aos 469 dap, em relação aos teores de algumas espécies químicas do solo, amostrados aos 272 dap.

\begin{tabular}{|c|c|}
\hline Parâmetros agrotecnológicos & Variáveis do solo correlacionadas $(r)$ \\
\hline Peso de biomassa, em t.ha ${ }^{-1}$ & $\begin{array}{l}\mathrm{Fe}\left(0,56^{\star}\right), \mathrm{K}\left(-0,68^{\star}\right), \mathrm{Ca}\left(0,81^{\star}\right) \mathrm{e} \\
\mathrm{Mn}\left(0,65^{\star}\right)\end{array}$ \\
\hline Tpol/ha, em t.ha ${ }^{-1}$ & $\begin{array}{l}\mathrm{pH}\left(0,71^{\star \star}\right), \mathrm{H}+\mathrm{Al}\left(-0,58^{\star \star}\right), \mathrm{Ca}\left(0,68^{\star \star}\right), \\
\mathrm{P}\left(0,72^{\star \star}\right), \mathrm{K}\left(-0,62^{\star}\right) \text { e } \mathrm{Mn}\left(0,49^{\star}\right)\end{array}$ \\
\hline TAH, em t.ha ${ }^{-1}$ & $\begin{array}{l}\mathrm{pH}\left(0,75^{\star \star}\right), \mathrm{H}+\mathrm{Al}\left(-0,63^{\star \star}\right), \mathrm{Ca}\left(0,71^{\star \star}\right), \\
\mathrm{P}\left(0,75^{\star \star}\right) \text { e } \mathrm{K}\left(-0,64^{\star}\right) \text { e } \mathrm{Mn}\left(0,51^{\star}\right)\end{array}$ \\
\hline $\mathrm{P}_{2} \mathrm{O}_{5}$ no caldo, em $\mathrm{mg} \cdot \mathrm{L}^{-1}$ & $\begin{array}{l}\mathrm{pH}\left(0,48^{\star}\right), \mathrm{Mg}\left(0,60^{\star \star}\right), \mathrm{P}\left(0,48^{\star}\right) \\
\mathrm{Cu}\left(0,63^{\star \star}\right), \mathrm{Zn}\left(0,69^{\star \star}\right), \text { e } \mathrm{Ni}\left(0,60^{\star}\right)\end{array}$ \\
\hline
\end{tabular}

${ }^{*} e^{* *}=$ significativos a 5 e $1 \%$ no teste $F$ 
Tabela 8. Valor de correlação entre as produtividades da cana-planta, expressa em colmos despontados colhidos aos 469-dap, em relação aos conteúdos das espécies quimicas nas folhas amostradas aos 272 dap .

\begin{tabular}{|c|c|}
\hline Parâmetros agrotecnológicos & $\begin{array}{l}\text { Espécies químicas nas folhas }+3 \\
\text { correlacionadas }(r)\end{array}$ \\
\hline Peso de biomassa, em t.ha ${ }^{-7}$ & $\mathrm{~K}\left(0,43^{\star}\right)$ e $\mathrm{B}\left(0,51^{\star}\right)$ \\
\hline \multirow[t]{3}{*}{ Tpol/ha, em t.ha ${ }^{-1}$} & $\mathrm{~N}\left(0,79^{\star \star}\right), \mathrm{P}\left(0,55^{\star \star}\right), \mathrm{K}\left(0,69^{\star \star}\right), \mathrm{Mn}\left(0,66^{\star \star}\right)$, \\
\hline & $\mathrm{Zn}\left(0,42^{\star}\right), \mathrm{Ni}\left(0,70^{\star *}\right), \mathrm{S}\left(0,55^{\star}\right)$ e Al(- \\
\hline & $\left.0,75^{\star \star}\right)$ \\
\hline \multirow[t]{2}{*}{$\mathrm{TAH}$, em t.ha ${ }^{-1}$} & $\mathrm{~N}\left(0,81^{\star \star}\right), \mathrm{P}\left(0,60^{\star \star}\right) ; \mathrm{K}\left(0,70^{\star \star}\right), \mathrm{Mn}\left(0,72^{\star \star}\right)$ \\
\hline & $\mathrm{Zn}\left(0,47^{\star}\right), \mathrm{Ni}\left(0,75^{\star \star}\right)$ e $S\left(0,71^{\star \star}\right)$ \\
\hline $\mathrm{P}_{2} \mathrm{O}_{5}$ no caldo, mg. $\mathrm{L}^{-1}$ & $N\left(-0,43^{*}\right), P\left(0,43^{*}\right), M n\left(0,50^{*}\right)$ e $S\left(-0,50^{\star *}\right)$ \\
\hline
\end{tabular}

${ }^{*} e^{* \star}=$ significativos a 5 e $1 \%$ no teste $F$ 


\subsection{Efeitos do Le nas Exportações de Espécies Químicas}

A sustentabilidade da produção de qualquer cultura só pode ocorrer quando o balanço de nutrientes no solo for nulo ou positivo. Para isto, é essencial que no mínimo reponham-se as perdas dos nutrientes que ocorreram no processo produtivo. Dentre as possiveis perdas de nutrientes no agrossistema canavieiro, têm importância as suas exportações pelos colmos, com ou sem as folhas.

As quantidades médias exportadas pelos colmos mais folhas de macronutrientes $\left(\mathrm{kg} \mathrm{ha}^{-1}\right)$ e de micronutrientes $\left(\mathrm{g}^{-\mathrm{ha}^{-1}}\right)$ dos tratamentos testemunha e aquele que recebeu a dose de 40 t.ha $^{-1}$ de Le, estão a seguir. Estes resultados são comparados com os obtidos por ORLANDO $\mathrm{F}^{\circ}$, (1978) e ORLANDO $\mathrm{F}^{\circ}$ et al. (1980) para a cultivar CB 4I-76 cultivada no solo Pvls e colhida aos 14 meses, os quais estão dispostos entre os parênteses: $N$ de 136 a $175 \mathrm{~kg}$ (167); P de 18 a $29 \mathrm{~kg}$ $(23,6) ; \mathrm{K}$ de 158 a $185 \mathrm{~kg}$ (183);Ca de 68 a $110 \mathrm{~kg}$ (96); Mg de 29 a 43 kg (56); de

35 a $59 \mathrm{~kg}$ (52); 319 a $500 \mathrm{~g}$ de B (275); 140 a $247 \mathrm{~g}$ de Cu (245); 6000 a $7500 \mathrm{~g}$ de Fe (4940); 2860 a $3120 \mathrm{~g}$ de $\mathrm{Mn}$ (2752) e de 318 a $470 \mathrm{~g}$ de $\mathrm{Zn}$ (693). Verifica-se que as faixas de variação para as quantidades exportadas de nutrientes pelos colmos mais folhas estão dentro da encontrada na literatura, excetuando-se as quantidades de $\mathrm{Fe}$ e de $\mathrm{Zn}$, que foram acima e abaixo destes valores.

Na Figura 14, visualizam-se os efeitos de doses de Le no aumento das exportações de $\mathrm{N}, \mathrm{K}, \mathrm{Ca}, \mathrm{P}, \mathrm{Mg}, \mathrm{S}, \mathrm{Al}, \mathrm{Fe}, \mathrm{Cu}$ e $\mathrm{B}$ pela parte aérea. Destes aumentos apenas parte deles foi motivada pelos aumentos nas concentraçöes dos nutrientes nos colmos + folha , mas sim devido a maior produtividade. 

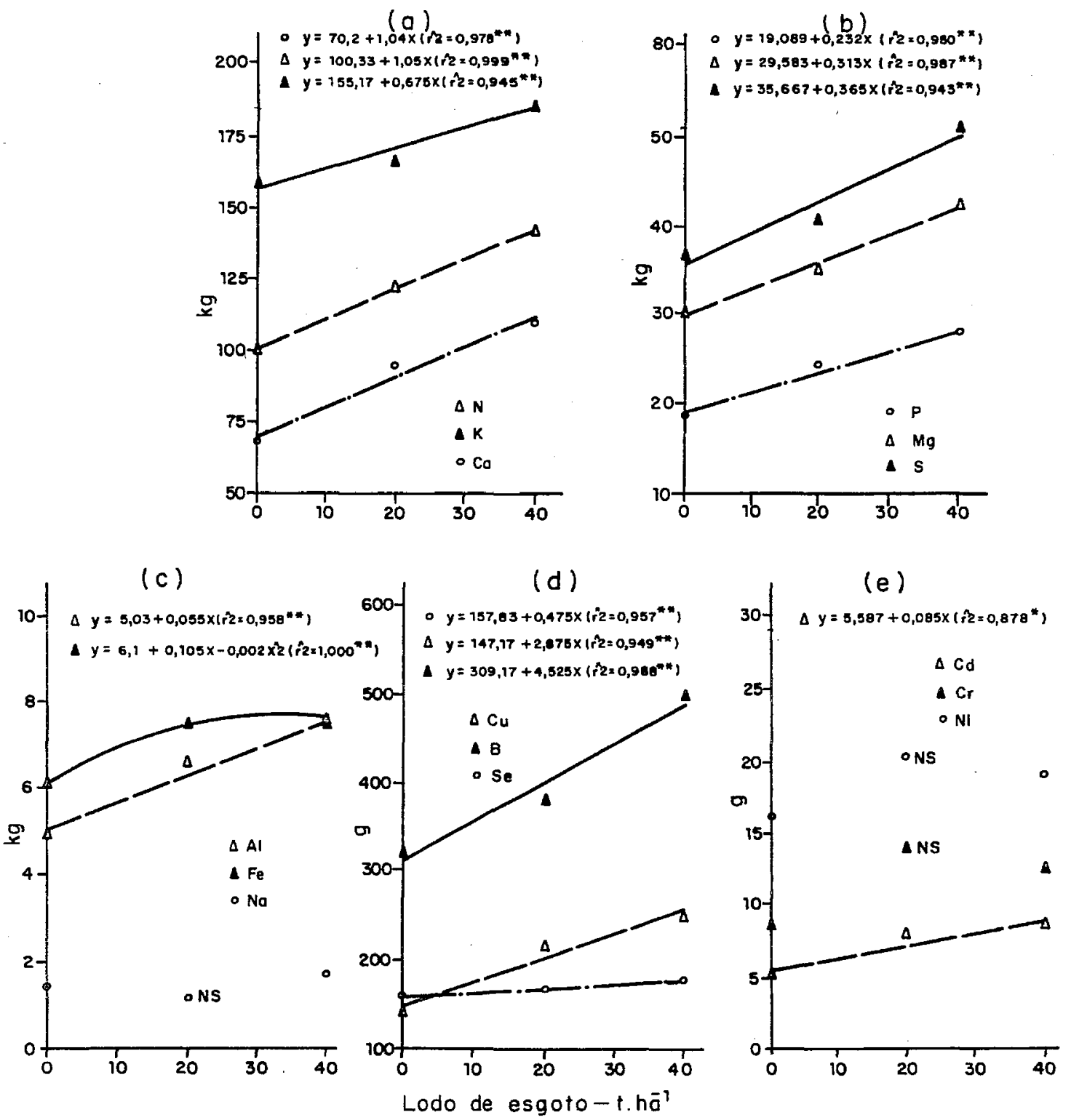

Figura 14- Influência da aplicação de doses de lodo de esgoto ao solo, no exportaçõo de nitrogênio, de połóssio, de cálcio (a), de fósforo, de magnésio, de enxofre (b), de aluminio, de ferro, de sódio (c), de cobre, de boro, de selênio(d), de códmio, de crómio e de níquel (e) pelos colmost folhas da cana-planta, oos 431 dap.

*-significativo a $5 \%$ de probabilidade, no teste $F$. * *-significativo a $1 \%$ de probabilidade, no teste $\mathrm{F}$. NS-não significativo, no teste $F$. 
Os aumentos de teores das espécies químicas nos tecidos causados pelo Le foram diferentes para cada nutriente, sendo o primeiro valor entre parênteses a testemunha, e o último para o tratamento que recebeu 40 t.ha ${ }^{-1}$ de Le : B $(4,0$ para 6,0 g), Ca (1,84 para 2,68 kg), Cu (4,0 para 5,9 g), S (1,0 para 1,4 kg) e Zn (9 para $11,3 \mathrm{~g}$ ), por tonelada, valores que se encontram na faixa de variação encontrada por PRIMAVESI et al. (1992). O efeito do Le em aumentar a exportação de nutrientes pelas culturas foi observado por vários autores. Por exemplo, $\mathrm{N}$ e $\mathrm{P}$ pelo milheto (ROS et al, 1993) e pela cana-de-açúcar (MARQUES, 1990), de N, P, Ca e S para sorgo granífero (DIAS, 1994) e de N, P, Ca, Mg e S pelo milho (BERTON et al, 1989).

A fórmula química ( $F=N S$ ) não influenciou a quantidade exportada de nutrientes pelos colmos mais folhas e tampouco, a interação dupla adubo químico $x$ Le foi significativa (Apêndice 6).

Do ponto de vista de aumentos nas exportações pelos colmos motivados pelo uso do Le (Figura 15), pode-se verificar pelas diferenças existentes entre as exportações da testemunha ( $1^{\circ}$ número, entre parênteses) e da dose de 40 t.ha ${ }^{-1}$ de Le ( $2^{\circ}$ número, entre parênteses), destacando-se: K (144 para 166 kg ), N( 107 para $145 \mathrm{~kg}$ ), Ca( 27 para $58 \mathrm{~kg}$ ), S (26 a $51 \mathrm{~kg}), \mathrm{Mg}(29$ para $40 \mathrm{~kg}$ ), $\mathrm{P}(17,4$ para 25,1 kg), Zn ( 358 para $458 \mathrm{~g}$ ), B( 259 para $304 \mathrm{~g}$ ), Cu( 227 para $368 \mathrm{~g})$ e $\mathrm{Ni}$ (10,4 para 22,3 g). Comparam-se, a seguir, as quantidades exportadas de nutrientes por tonelada de colmos despontados e queimados pela testemunha sem adubação ( $1^{\circ}$ número), e pelo tratamento que recebeu $40 \mathrm{tha}^{-1}$ de Le $\left(2^{\circ}\right.$ número), com a literatura para a cana-planta ( cultivar CB41-76) colhida aos 16 meses cultivada no solo Pvls. 
(a)

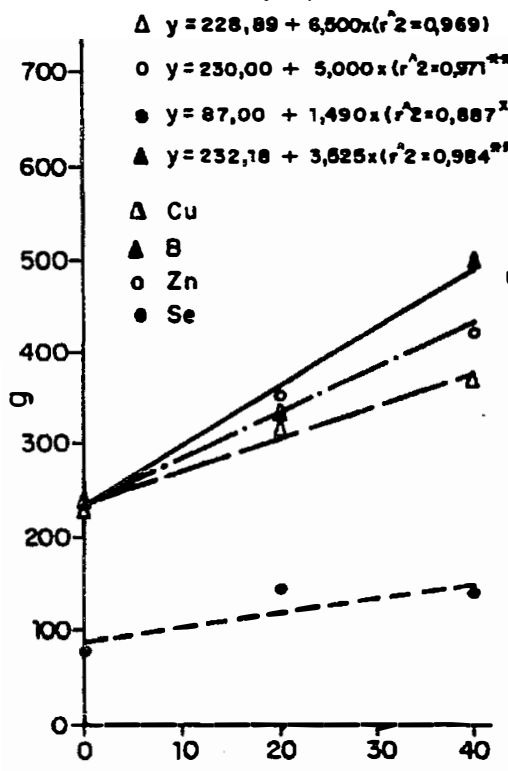

(d)

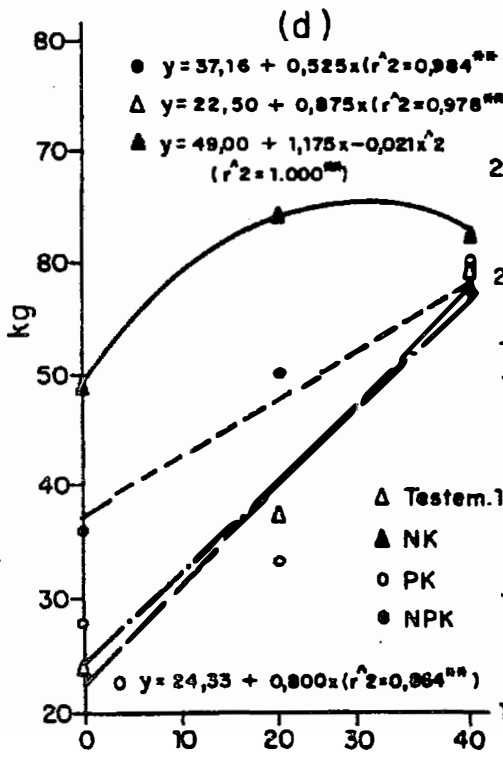

(b)

$\Delta y=16,50+0,13 \times\left(r^{2}=0,893^{n * x}\right)$

$\Delta y=13,25+0,10 \times\left(r 2=0,942^{m+1}\right) 50$

o. $y=15,00+0,01 \times\left(r^{2} 2=1,000^{* *}\right.$ )

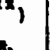

\section{(1)}

21- $0 \mathrm{Cd}$

$\Delta \mathrm{Cr}$

$\Delta N I$

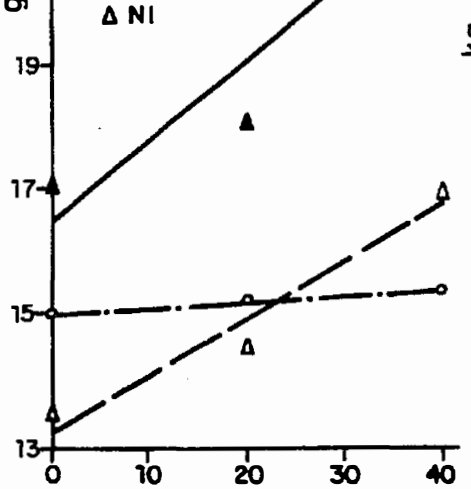

Lodo de esgoto - t. hö (e)

o $y=185,0+1,25 \times\left(r^{\wedge} 2=0,093^{* *}\right)$

$\Delta y=132,3+0,875 \times\left(r^{n}=0,942^{n \pi}\right)$

$\Delta y=150,0+0,10 \times\left(\hat{r}=1,000^{* n}\right)$
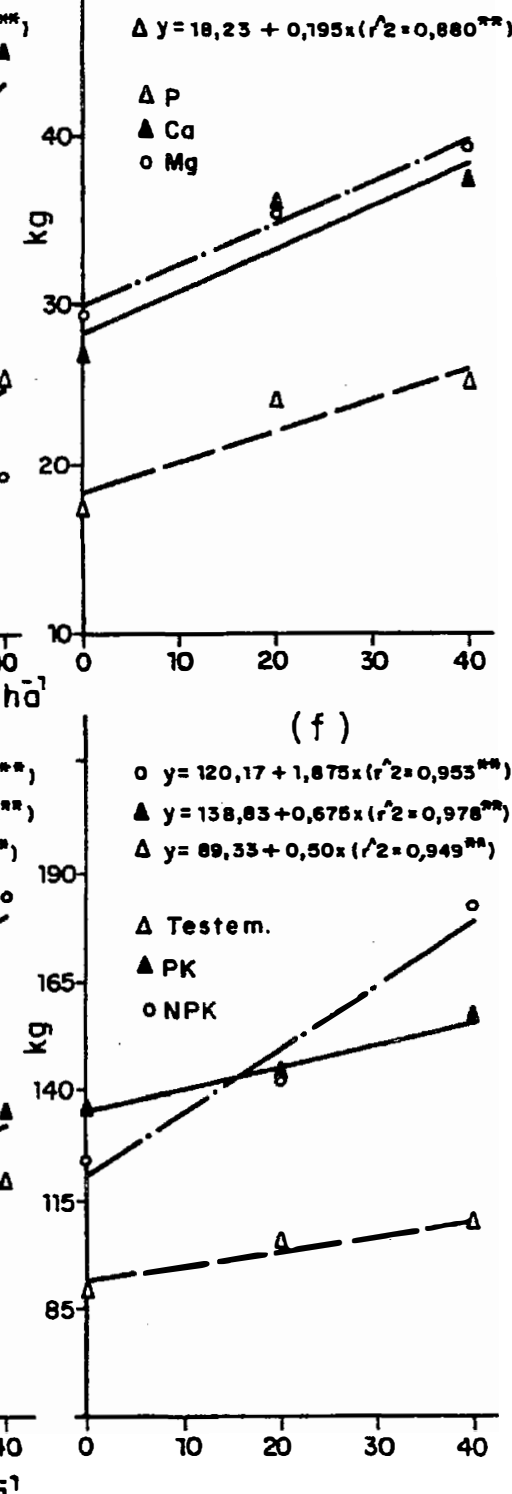

(f)

- $y=120,17+1,675 \times\left(r^{\wedge} 2=0,953^{n+h}\right)$

$\Delta y=138,03+0,678 \times\left(r^{n} 2=0,978^{20 n}\right)$

$\Delta y=09,33+0,50 \times\left(f_{2}=0,949^{m+n}\right)$

(c)

O $y=29,70+0,255 \times\left(\hat{r}_{2}=0,982^{n * *}\right)$

$\Delta y=28,25+0,203 \times\left(r^{2}=0,055 \mathrm{~km}\right)$

$\Delta$ Testem.

$\triangle$ PK

ONPK

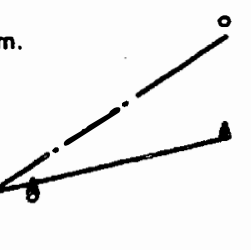

Figura 15 - Influência da aplicação de doses de lodo de esgoto ao solo, no exportaçāo de cobre, de boro, de zinco, de selénio(a), de códmio, de crômio e de níquel (b), de fósforo, de calcio, de magnésio (c), de enxofre (d), de potássio (e) e de nitrogénio ( $f$ ) pelos colmos do cona-planta, oos 472 dap.

* significativo a $7 \%$ de probabilidade, no teste $F$. 
(ORLANDO $\mathrm{F}^{\circ}, 1978$ e ORLANDO $\mathrm{F}^{\circ}$ et al., 1980), dispostos entre parênteses: $\mathrm{N}$ de 2,2 a $2,5(3,0) \mathrm{kg} ; 0,5$ a $0,6(0,6) \mathrm{kg}$ de $\mathrm{P} ; 0,76$ a $0,96(0,90) \mathrm{kg}$ de S; 10 a $11(15) \mathrm{g}$ de $\mathrm{Zn} ; 44$ a $37(44) \mathrm{g}$ de Mn e de 6,8 a 8,6 (6,25) g de Cu. O confronto dos resultados permite verificar que apenas $\mathrm{O} \mathrm{Zn}$ nos colmos estaria mais baixo, mas perfeitamente dentro da faixa de variação encontrado por PRIMAVESI et al. (1992 ).

A ordem de exportação de macronutrientes pela cana-planta foi: $K>N>$ $\mathrm{S}>\mathrm{Ca}=\mathrm{Mg}>\mathrm{P}$. Esta seqüência está em concordância com a obtida por ORLANDO $\mathrm{F}^{\circ}$ (1978), na qual se destaca o $\mathrm{N}$ e $\mathrm{K}$ como os mais exportados, sendo o $\mathrm{P}$ removido em menor quantidade. Se comparados aos valores médios exportados pelos

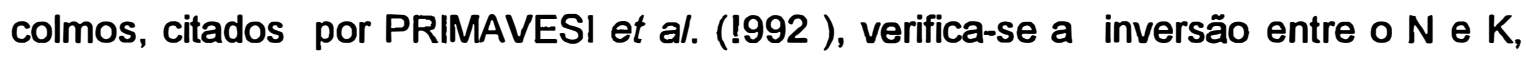
como os mais exportados, e a concordância para os demais nutrientes.

Quando se comparam por unidade de área as exportações de nutrientes pelos colmos com as de colmos mais folhas da cana-planta, verifica-se que a presença de folhas aumenta as exportações de $\mathrm{N}, \mathrm{Mg}, \mathrm{S}$ e $\mathrm{Zn}$, o que está de acordo com os resultados da literatura (ORLANDO $\mathrm{F}^{\circ}, 1978$ e ORLANDO $\mathrm{F}^{\circ}$ et al., 1980).

As quantidades dos elementos contidos no resíduo na dose de 40 t.ha ${ }^{-1}$, expressas em kg.ha-1 são: $\mathrm{B}(0,15), \mathrm{Ca}(172), \mathrm{Cu}(14), \mathrm{Fe}(760), \mathrm{K}(22), \mathrm{Mg}(52), \mathrm{Mn}$ (8), N (334), P (150), S (150) e Zn (28). Comparando-se as quantidades máximas de nutrientes exportadas pelos colmos mais folhas, com as quantidades de nutrientes adicionadas pela citada dose de Le, constata-se que o balanço foi positivo, exceto para $\mathrm{Ke} \mathrm{B}$, cujo balanço foi negativo. Se considerado apenas os colmos, o balanço foi positivo para todos os nutrientes, exceto para o B. 


\section{CONCLUSÕES}

1. O lodo de esgoto (Le) atuou como corretivo do complexo coloidal do solo e como fertilizante para a cultura de cana-de-açúcar, principalmente como fonte de $\mathrm{Ca}, \mathrm{P}$, S e Zn.

2. Os efeitos do Le no sistema solo-planta foram de curta duração, ou seja, se restringiu a apenas 1 ano agricola.

3. A adição de Le ao solo promoveu o incremento de produção de biomassa de colmos, o que ocasionou aumento proporcional de produtividade de açúcar. O Le não alterou a maturação e a concentração de açúcar nos colmos da cana-deaçúcar, pois não se modificaram o Brix, pol, fibra, açúcares redutores e pureza.

4. O balanço de nutrientes no sistema solo-planta foi positivo, exceto para o $\mathrm{K} \mathrm{e} \mathrm{B}$, pois as quantidades adicionadas na forma de Le superaram as exportaçòes pela retirada da parte aérea. 
5. Os aumentos nos teores de metais pesados no solo e nos colmos, devido ao uso de Le, foram da ordem de valor que não ofereceu qualquer risco de passagem a cadeia trófica e se acumularem no produto final. 


\section{REFERÊNCIAS BIBLIOGRÁFICAS}

ADRIANO, D.C. Trace elements in the terrestrial environment. New York. SpringerVerlag, 1986.533p.

ALEXANDER, A.G. Sugarcane physiology. Amsterdam, Elselvier, 1973. 752p.

ALLAWAY, W.H. Agronomic controls over the environmental cycling of trace elements. Advances in Agronomy, New York, $\underline{20}$ :235-74, 1968.

ALLOWAY, B.J. Soil processes and the behaviour of metal. In: - Heavy metals in soils. New York, John Wiley, 1990. p.7-39.

ALMY, A.A.; BLAKESLEE, P.A.; CONDOR, L.J.; ISLEIB, D.R.; JACOBS, L.W.; LIBBY, L.W.; LOUDON, T.L.; NELSON, R.E.; STEPHENS, L.D.; NOEROP, E.T. van. Land application of municipal cooperative extension service.. Michigan, Michigan State University, 1977 (Extension Bulletin, E-1081). 
AMORIM, H.V. Nutrição mineral de leveduras: aspectos teóricos e práticos. In: SEMANA DE FERMENTAÇÃO "JAIME ROCHA DE ALMEIDA", 4.,Piracicaba, 1985. Anais. Piracicaba, STAB, 1985. 149p.

ANDERSON, R.L.; BURD, R.S.; HART, S.A.; NELSON, D.C.; SIEBERT JR., C.L.; STRELOW, J.L.; WILEY, J.S. Utilization of municipal wastewater sludge. Washington, Technical Practice Committee, Subcommittee on Utilization of Municipal Wastewater Sludge, 1972. 46p. (Manual of Practice, 2).

ANTÓN, D.F.P. Efeitos da toxidez de níquel em arroz e feijão. Piracicaba 1990. 144p. (Doutorado - Escola Superior de Agricultura "Luiz de Queiroz"/USP).

AUBERT, H. \& PINTA, M. Trace elements in soils. Amsterdam, Scientific Publ., 1977. 395p.

AYUSO, M.; HERNANDEZ, C.; GARCIA, C.; COSTA, F. Utilización de un lodo aerobio como substituto de fertilizantes fosforados inorganicos. Suelo y Planta, Madrid, 2:280-91, 1992.

BAKER, D.E., ed. Criteria and recommendations for land application of sludges in the northeanst. Athens, Agric. Exp. Stn., 1985. 851p. (Bulletin, 851).

BARBER, S.A. Soil nutrient bioavailability. New York, John Wiley, 1984. 398p. 
BATAGLIA, O.C.; BERTON, R.S.; CAMARGO, O.A.; VALADARES, J.M.A.S. Resíduos orgânicos como fonte de nitrogênio para capim-braquiária. Revista Brasileira de Ciência do Solo, Campinas, 7: 277-81, 1983a.

BATAGLIA, O.C. \& RAIJ, B. van. Eficiência de micronutrientes na análise do solo. Revista Brasileira de Ciência do Solo, Campinas, 13(2):205-12, 1989.

BATAGLIA, O.C.; FURLANI, A.M.C.L.; TEIXEIRA, J.P.F.; FURLANI, P.R.; GALLO, J.R. Métodos de análise química de plantas. Campinas, Instituto Agronômico, 1983b. 48p. (IAC. Boletim Técnico, 78).

BEAUCLAIR, E.G.F. de. Produtividade da cana-de-açúcar em função de alguns macronutrientes presentes no caldo e no solo. Piracicaba, 1994. 97p. (Doutorado - Escola Superior de Agricultura "Luiz de Queiroz"/USP).

BECKETT, P.H.T. Critical tissue concentrations as indicadors of toxicity. Suelos Ecuatoriales, Bogota, 21(2):39-44, 1991.

BERNARDES, L.F. Efeitos da aplicação de lodo de esgoto nas propriedades físicas do solo. Jaboticabal, UNESP/FCAV, 1982. 50p. 
BERTON, R.S. Fertilizantes e poluição. In: REUNIÃO BRASILEIRA DE FERTILIDADE DO SOLO E NUTRIÇÃO DE PLANTAS, 20., Piracicaba, 1992. Anais. Campinas, Fundação Cargill, 1992. 425p.

BERTON, R.S.; CAMARGO, O.A.; VALADARES, J.M.A.S. Absorção de nutrientes pelo milho em resposta à adição de lodo de esgoto à cinco solos paulistas. Revista Brasileira de Ciência do Solo, Campinas. 13:187-92, 1989.

BESFORD, R.T. Nutrients imbalances in tomato plants and acid phosphatase activity in the leaves. Journal Science Food Agriculture, Oxford, 30(4):275-80, 1979.

BETTIOL, W. \& CARVALHO, P.C.T. Utilização de lodo de esgoto primário e fertilizantes organo-mineral IPT na cultura de milho. Fertilizantes, São Paulo, $\underline{4}(1): 14-5,1982$.

BETTIOL, W.; CARVALHO, P.C.T.; FRANCO, B.J.D.C. Utilização do lodo de esgoto como fertilizante. O Solo, Piracicaba, 75(1):44-54, 1983.

BETTIOL, W.; FRANCO, B.J.D.C.; CARVALHO, P.C.T. Utilização de lodo de esgoto como fertilizante para cultura de arroz ( Oryza sativa L. cv. IAC-165). In: CONGRESSO BRASILEIRO DE INICIAÇÃO CIENTÍFICA EM CIÊNCIAS AGRÁRIAS, 2., Piracicaba, 1982. Anais. Piracicaba, ESALQ, 1982. p.218-9. 
BINGHAM, F.T.; PAGE, A.L.; STRONG, J.E. Yield and cadmium content of rice grain relation to addition rates of cadmium, copper, nickel and zinc with sewage sludge and liming. Soil Science, Baltimore, 130(1):32-8, 1980.

BITTENCOURT, V.C. de; PAIXÃO, A.C.S.; ALMEIDA, M.J.; BEAUCLAIR, E.G.F. de. Diagnose nutricional da cana-de-açúcar através da análise do caldo. I. Dados preliminares. STAB. Açúcar, Álcool e Subprodutos, Piracicaba, 11(2):12-7, nov./dez. 1992.

BOARETTO, A.E. , Coord. Uso de lodo de esgoto como fertilizante. Botucatu, FINEP, 1986. 185p.

BOARETTO, A.E.; MURAOKA, T.; NAKAGAWA, J.; CHITOLINA, J.C. Niquel e cadmio em grãos de feijão produzidos em solo incubado com lodo de esgoto. In: REUNIÃO BRASILEIRA DE FERTILIDADE DO SOLO E NUTRIÇÃO DE PLANTAS, 20., Piracicaba, 1992. Anais. Campinas, Fundação Cargill, 1992. p.400-1.

BREWER, R.F. Diagnostic criteria for plants and soils. Riverside, University of California/ Division of Agricultural Sciences, 1965. p.180-96. 
BROWNE, J. \& ZERBAN, F.W. Physical and chemical methods of sugar analysis. 3 ed. New. York, John Wiley, 1941. 1353p.

BUTING, A.H. Experiments on organic manures. Journal Agriculture Science, London, $\underline{60}: 121-40,1963$.

CABRE, J.; ARRAEZ, J.; ARAGONESES, R. Utilizacion de un lodo aerobio como sustitutivo de fertilizantes fosforados inorgânicos. Suelo $\$ Planta Madrid, 2(2):280-2, 1990.

CARDOSO, E.J.B.N. Degradação de resíduos orgânicos pela microbiota do solo. In: REUNIÃO DE FERTILIDADE DO SOLO E NUTRIÇÃO DE PLANTAS, 20., Piracicaba, 1992. Anais. Campinas, Fundação Cargill, 1992. p.179-93.

CARVALHO, P.C.T. Utilização de lodos de esgoto na agricultura. In: COLOQUIO REGIONAL SOBRE MATÉRIA ORGÂNICA DO SOLO, IPT/CEFER, São Paulo, 1982. São Paulo, IPT, 1983, p.223-6.

CARVALHO, P.C.T. \& BARRAL, M.F. Aplicação de lodo de esgoto como fertilizante. Fertilizantes, São Paulo, $\underline{3}(2): 1-4,1981$.

CASANOVAS, H. \& ARMAS, R. de. Influence of potassium upon mineral and aconitic acid contents of sugar cane juices. In:INTERNATIONAL SOCIETY SUGAR 
CANE TECHNOLOGY.19, Proceedings. 19, Havana, 1983. Cuba, ISSCT, 1983, p.639-57.

CAST - (COUNCIL FOR AGRICULTURAL SCIENCE AND TECHNOLOGY). Organic and conventional farming compared. Illinois, 1980. 32p. (Report, 84).

CESAR, M.A.A. \& SILVA, F.C. da. A cana-de-açúcar como matéria prima para a indústria sucroalcooleira. Piracicaba, CALQ, 1993. 107p.

CESAR, M.A.A.; DELGADO, A.A.; GABAN, L.C. Aumento do nivel de amido e de potássio no caldo de cana decorrentes da aplicação sistemática de vinhaça ao solo. Brasil Açucareiro, Rio de Janeiro, 92(1): 24-9, 1978.

CESAR, M.A.A.; DELGADO, A.A.; BRESSAN, W.; SILVA, F.C. da. Influência de alguns não açúcares orgânicos e inorgânicos na viscosidade de melaço, durante a fabricação do açúcar de cana. Usineiro, São Paulo, 4(16):37-48, 1989.

CESAR, M.A.A.; DELGADO, A.A.; CAMARGO, A.P.; BISSOLI, B.M.A.; SILVA, F.C. da. Capacidade de fosfatos naturais e artificiais e, elevar o teor de fósforo no caldo de cana-de-açúcar (cana-planta), visando o processo industrial. STAB. Açúcar, Álcool e Subprodutos, Piracicaba, $\underline{5}(5 / 6):$ 32-8, 1987. 
CHANEY, R.L. Urban/industrial - agricultural interactions: heavy metals limit beneficial use of sewage sludge composts in agricultural. In: HEATING ON AGRICULTURAL PRODUCTIVITY AND ENVIRONMENTAL QUALITY. Columbus, 1979. Proceedings. Columbus, University of Ohio; Science and Technology Committee, 1979. p.1-14.

CHANEY, R.L. Metal speciation and interaction among elements effect trace element transfer in agricultural and environmental food-chains. In: KRAMER, J.R. \& ALLEN, H.E., ed. Metal speciation theory analysis application. Chelsea, Lewis Publ., 1988. p.219-60.

CHANEY, R.L. \& GIORDANO, P.M. Micronutrients as related to plant deficiences and toxicities. In: ELLIOTI, L.F. \& STEVENSON, F.J., ed. Soil for management of organic wastes and waste waters. Madison, Soil Science Society American, 1986. p.234-79.

CHANG, A.C.; GRANATO, T.C.; PAGE, A.L. A methodology for establishing phytotoxicity criteria for chromium, copper, nickel, and zinc in agricultural land application of municipal sewage sludges. Journal of Environmental Quality, Madison, 21(4): 521-36, 1992. 
CHANG, A.C.; PAGE, A.L.; WARNEKE, J.E. Long term sludge applications on cadmium and zinc accumulation in swiss chard and radish. Journal Environmental Quality, Madison, 16(3):217-21, 1987.

CLARK, R.B.; PIER, P.A.; KNUDSEN D.; MARANVILLE, I.W. Effect of trace element deficiencies and excesses on mineral nutrient in sorghum. Journal of Plant Nutrition, New York, $\underline{3}(1 / 4): 357-74,1981$.

CLEMENTS, H.F. Sugarcane crop logging and crop control. Honolulu, Univ. Press, Hawaii, 1980. 520p.

CORDEIRO, D.A. Efeitos da calagem e adubação potássica sobre a produção de colmo e equilíbrio nutricional da cana-de-açúcar (Saccharum spp). Piracicaba, 1978. 59p. (Mestrado - Escola Superior de Agricultura "Luiz de Queiroz"/USP).

COTTENIE, A. Sludge treatment and disposal in relation to heavy metals. In: INTERNATIONAL CONFERENCE HEAVY METALS IN THE ENVIRONMENT., Edinburg, 1981. Proceedings. Edinburg, CEP Consultants, 1981. p.167-75.

CUNNINGHAM, I.D.; KEENEY, D.R.; RYAN, J.A. Yield and metal composition of cron arid rye grown on sewage sludge ammended soil. Journal Environmental Quality, Madison, 4:448-54, 1975. 
DAVIES, B.E. Trace element pollution. In: - ed. Applied soil trace elements. Chichester, John Wiley, 1980. 482p.

DEAN, R.B. \& SMITH, J.E. The properties of sludges. In: — Recycling municipal and effluents on land. Washington, Nat. Assoc. St. University of Land-Grant Cool. 1973. p.39-49.

DELGADO, A.A. \& CESAR, M.A.A. Elementos de tecnologia e engenharia do acúcar de cana. Piracicaba, De Gaspari, 1977. $1061 p$.

DELGADO, A.A. \& CESAR, M.A.A. Determinação de fosfatos em caldo e mosto de

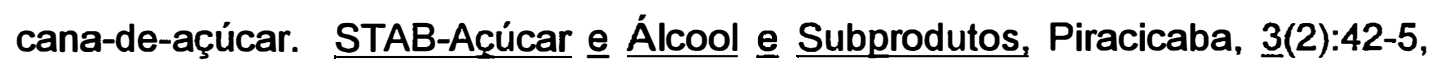
1984.

DIAS, F.L.F. Efeito da aplicação de calcário, lodo de esgoto e vinhaca em solo cultivado com sorgo granifero (Sorghum bicolor L.). Jaboticabal, UNESP/FCAV, 1994. 74p.

DUDAS, M.J. \& PAWLUK, S. Trace elements in sewage sludge and metal uptake by plant grown in sludge-amended soil. Canadian Journal Soil Science, Ottawa, 55:239-43, 1975. 
EL WALI, A.M.O. \& GASCHO, G.J. Fertilization of sugarcane using critical nutrient leves. Sugar Journal, New York, 46(80):9-11, 1984.

ESTADOS UNIDOS. United States of Agency Protection Environment. - EPA. Standart for the Use or Disposal of Sewage Sludge. Washington, Federal Register, v.58, n.32, p.9248-9415, February 1993.

ESTADOS UNIDOS. Department of Agriculture -USDA. Report and recommendation on organic farming. Washington. 1980. 94p.

EVANS, H. Tissue diagnostic analysis and their interpretation in sugarcane. In: INTERNATIONAL SOCIETY SUGAR CANE TECHNOLOGISTS, 12., Puerto Rico, 1965. Proceedings. Amsterdam, Elsevier, 1967. p.156-80.

FAO. Organic recycling in Asia. FAO Soils Bullettin, Rome, 36:320-5, 1978.

FERNANDES, A.C. Controle da cana-de-açúcar como matéria prima na fabricação do açúcar e do álcool. São Paulo, COPERSUCAR, 1986. 41p. (Série Agronômica, 3).

FERGUSON, J.E. Heavy elements; chemistry environment impact and healthy effects. London, Pergamon Press, 1990. 614p. 
FLAIG, W. Biochemistry of soil organic matter. FAO Soils Bull.etim, Roma; .31-9, 1975.

FORTUNY, J.A. \& FULLER, W.H. Trace metals in municipal sludges. Evaluation procedures for solid wastes. Biocycle; Journal of Waste Recycling, Emmaus. $\underline{20}: 27-9,1979$.

FREIRE, E.S.; ALVAREZ, R.; WUTKE, A.P.C. Adubação da cana-de-açúcar, 13. Estudos conjuntos de experiências com diversos fosfatos realizados entre 1950 e 1963. Bragantia, Campinas, 27(34):421-36, 1968.

FULLER, W.H. \& WARRICK, A.W. Soils in waste treatment and utilization. CRC Boca Raton, CRC Press, 1985. v.1, 268p.

GALLO, J.R.; HIROCE, R.; ALVAREZ, R. Amostragem de cana-de-açúcar para fins de análise foliar. Bragantia, Campinas, 21(54):899-921, 1962.

GALLOWAY, H.M. \& JACOBS, L.W. Sewage sludge. I. Caracteristics and management. Utilization of municipal sewage was and sludges on land for agricultural production. Washington, North Central Regional Extention Publication, 1977. p.3-17. 
GILPIN, L. \& JOHNSON, A.H. Fluorine in agricultural soils of Southeastern Pennsylvania. Soil Science Society America Journal, Madison, 44:255, 1980.

GIORDANO, P.M. \& MAYS, D.A. Plant nutrient from municipal sewage sludge. Industry \& Engineering Chemistry Product and Research Development, Washington, D.C., 20(2):212-16, 1981.

GLORIA, N.A. da. Efeito do potássio na acumulação de sacarose pela cana-deaçúcar. Álcool \& Açúcar, São Paulo, 5 (23):20-5, 1985.

GLÓRIA, N.A. da. Uso agronômico de resíduos. In: REUNIÃO BRASILEIRA DE FERTILIDADE DO SOLO E NUTRIÇÃO DE PLANTAS, 20., Piracicaba, 1992. Anais. Campinas, Fundação Cargill, 1992. p.200-11.

GLORIA, N.A. da \& MAGRO, J.A. Utilização agrícola de resíduos da usina de açúcar e destilarias de álcool na usina da Pedra. In: SEMINÁRIO COPERSUCAR DA AGROINDÚSTRIA CANAVIEIRA, 4., Águas de Lindóia, 1976. Anais. Piracicaba, Copersucar, 1976. p.163-80.

GOLDEN, L.E. Micronutrient studies with sugarcane in Louisiana. American Society Sugarcane Technologist, New Orleans, $\underline{6}: 88-92,1976$.

GOMES, J.P. Curso de estatística experimental. São Paulo, Nobel, 1985. 466p. 
GOTO, R. Efeito de doses de diferentes adubos orgânicos na cultura de cebola (Allium cepa L.) de verão. Botucatu. 1983. 78p. (Mestrado - Faculdade de Ciências Agronômicas e Veterinárias/UNESP).

GROVE, J.H. \& ELLIS, B.G. Extractable chromium as related to soil pH and applied chromium. Soil Science Society of America Journal, Madison, 44(2):283-42, 1980.

GUIMARÃES, C.R.B.; BOARETTO, A.E.; NAKAGAWA, J. Utilização do lodo de esgoto em comparação com fertilizantes químicos feijão irrigado. In: CONGRESSO BRASILEIRO DE INICIAÇÃO CIENTÍFICA EM CIÊNCIAS AGRÁRIAS, 2., Piracicaba, 1982. Anais. Piracicaba, ESALQ. 1982. p.216-8.

GUSHI, R.S.; BOARETTO, A.E.; NAKAGAWA, J. Utilização do lodo de esgoto em comparação com fertilizantes químicos - feijão não irrigado. In: CONGRESSO BRASILEIRO DE INICIAÇÃO CIENTÍFICA EM CIÊNCIAS AGRÁRIAS, 2., Piracicaba, 1982. Anais. Piracicaba, ESALQ. 1982. p.214-6.

GUTIERREZ, L.E.; FERRARI, S.E.; GERALD, L.T.S.L.; ORELLI JR, A.A. Efeito da aplicação de vinhaça como fertilizante sobre os teores de ácido trans-aconítico de caldo de cana-de-açúcar (Saccharum spp). Anais da Escola Superior de Agricultura "Luiz de Queiroz", Piracicaba, 45 (pt. 2): 453-62, 1988. 
HAAG, H.P.; ORLANDO FILHO, J.; SARRUGE, J.R.; ZAMBELLO JR, J.E.; ROSSETTO, A. Utilização da vinhaça em solo argiloso e composição química da cana-de-açúcar (Saccharum spp). O Solo, Piracicaba, 72(2):5-9, 1980.

HALSTEAD, R.L.; FINN, B.J.; MACLEAN,A.J. Extractability of nickel added to soils and its concentration in plants. Canadian Journal of Soil Science, Ottawa, 49:335-42, 1969.

HEWITT, E.J. Metal interrelationships in plant nutrition. I. Effects of some metal toxicities on sugar beet, tomato, oat, potato and marrowastem kale grown in sand culture. Journal of Experimental Botany, London, 4:59-64, 1953.

HONIG, D. No azucares inorganicos. In: - Princípios de tecnologia azucarera. Mexico, Continental , 1969. 3v. 2045p.

HUMBERT, R.P. The growing of sugarcane. New York, Elsevier, 1968. 779p.

HUNTER, J.G. \& VERGANO, O. Nickel toxicity in plants. Annals of Applied Biology London, $\underline{39}: 279-84,1952 a$.

HUNTER, J.G. \& VERGANO, O. Trace element toxicities in oat plants. Annals of Applied Biology, London, 40:761-77, 1952b. 
INSTITUTO AGRONÔMICO DE CAMPINAS. Extração de boro pelo cloreto de báriomicroondas. In: IAC. Micronutrientes em solos métodos analíticos adotados pelo IAC. Campinas, IAC/FAPESP, 1994.

IPT/CETESB. Aproveitamento do lodo de esgoto como fertilizante. São Paulo. 1983. v.2.

JURADO, S.G. Efeitos do cadmio no arroz (Oryza sativa L.) e no feijoeiro (Phaseolus vulgaris L.) cultivados em solução nutritiva. Piracicaba, 1983. 139p. (Mestrado - Escola Superior de Agricultura "Luiz de Queiroz"/USP).

KABATA-PENDIAS, A. \& PENDIAS, H. Trace elements in soils and plants. Boca Raton, CRC Press, 1986. 315p.

KEEFER, R.F.; SINGH, R.N.; HORVATH, D.J.; KHAWAJA, A.R. Heavy metal availability to plants from sludge application. Bioycle; Journal of Waste Recycling, Emmaus., 20(3):31-4, 1979.

KELLING, K.A.; KEENEY, D.R.; WALSH, L.M.; RYAN, J.A. A field study of the agriculture use of sewage sludge. III. Effect of uptake and extractabiling of sludge - borne metals. Journal Environmental Quality, Madison, $\underline{6}: 352-8,1977$. 
KELLING, K.A.; PETERSON, A.E.; WALSH, L.H.; RYAN, J.A.; KEENEY, D.R. A field study of the agricultural use of sewage. I. Effect on crop yield and uptake on $\mathrm{N}$ and P. Journal Environmental Quality, Madison, $\underline{3}(4): 376-80,1974$.

KIEKENS, J.J. \& COTTENIE, A. Principles of investigation on the mobility and plant uptake of heavy metals. In: LESCHBER, R.; DAVIES, R.D.; L'HERMITÉ, P. Chemical methods for assessing bioavalable metals in sludge and soils. London, Elsevier, 1985. p.32-41.

KIRKHAM, M.B. Organic matter and heavy metal uptake. Biocycle; Journal of Waste Recycling, Emmaus, 18:18-21, 1977.

KITAGISHI, K. \& YAMANE, I. Heavy metal pollution in soils of Japan. Tokyo, Japan Science Society Press, 1981. 302p.

KLIEMANN, H.J. Contribuição ao estudo da disponibilidade de enxofre em solos brasileiros. Piracicaba, 1987. 231p. (Doutorado - Escola Superior de Agricultura “Luiz de Queiroz”(USP).

KNEZEK, B.D. \& ELLIS, B.G. Essential micronutrients. IV. Cooper, iron, manganese and zinc. In: DAVIES, B.E. ,ed. Applied soil trace elements. Chicester, John Wiley, 1980. 
KNIGHT, A.H. \& CROOKE, W.M. Interaction between nickel and calcium in plants. Nature, London, 178:220, 1956.

LAMBAIS, M. R. Microbiologia e poluição do solo. Piracicaba, ESALQ, 1988. 63p.

LAMY,I.; BOURGEOIS, S.; BERMUND, A. Soil cadmium mobility as a consequence of sewage sludge disposal. Journal of Environmental Quality, Madison. $\underline{22(4): 731-7, ~} 1993$.

LEAL, A.; GOMEZ, M.; SANCHEZ, RAYA, J.A.; YANEZ, J.; RECALDE, L. Effect of boron absorption on accumulation and distribution of phosphate. Controle de L'alimentation des plantes cultivels, Budapest, 1972. 763p.

LINDEN, D.R.; CLAPP, C.E.; DAWDAY, RIHI. Hidrologic managements: nutrients. In: -" Utilization of municipal waste water and sludge on land. Riverside, University of California, 1983. p.79-103.

LINDSAY, W.L. Inorganic phase equilibria of micronutrients in soils. In: MORTVEDT, J.J.; GIORDANO, P.M.; LINDSAY, W.L. Micronutrients in agriculture. Madison, Soil Science Society America, 1972. p. 41-57. 
LINDSAY, W.L. \& NORVELL, W.A. Development of a DTPA soil test for zinc, iron, manganese and cooper. Soil Science Society of America Journal, Madison, 42:421-8, 1978.

LOGAN, T.J. \& CHANEY, L.R. Metals. In: WORKSHOP ON UTILIZATION OF MUNICIPAL WASTEWATER AND SLUDGE ON LAND, Riverside, 1983. Proceedings. Riverside, University of California, 1983. p.235-323.

LOGAN, T.J. \& MATTIAZZO-PREZOTTO, M.E. Avaliação da possibilidade de uso agronomico de lodo de esgoto tratado com resíduo de indústria de cimento (CKD-Sludge). In: REUNIÃO BRASILEIRA DE FERTILIDADE DO SOLO E NUTRIÇÃO DE PLANTAS, 20., Anais. Piracicaba, 1992. Resumo. Campinas, Fundação Cargill, 1992, p.386-7.

LUCAS, R.E. \& KNEZEK, B.D. Climate and soil conditions promoting micronutrients deficiences in plants. In: MORTVEDT, J.J.; GIORDANO, P.M.; LINDSAY, W.L., ed. Micronutrients in Agriculture. Madison, Soil Society American, 1972. p.26588.

MALAVOLTA, E. Manual de química agrícola; nutrição de plantas e fertilidade do solo. São Paulo, Agronomica Ceres, 1976. 528p. 
MALAVOLTA, E. Elementos de nutrição mineral de plantas. São Paulo. Agronomica Ceres, 1980. 251p.

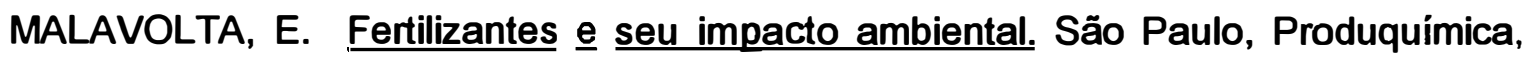
1994. 191p.

MALAVOLTA, E. \& COURY, T. Nutrição mineral de cultura de interesse econômico. São Paulo Agrícola, São Paulo. $\underline{\mathbf{5}}(56): 21-49,1963$.

MALAVOLTA, E.; GOMES, F.P.; COURY, T.; ABREU, C.P.; VALSECHI, O.; HAAG, H.P.; BRASIL SOCRINHO, M.O.C.; MELLO, F.A.F.; ARZOLLA, J.D.P.; RANZANO, G.; KIEHL, E.J.; CROCOMO, O.J.; MENARD, L.N.; NOVAES, E.R.; FREIRE, O.; OLIVEIRA, E.R. A diagnose foliar na cana-de-açúcar, 4. Resultados de 40 ensaios fatoriais NPK, $3 \times 3 \times 3$, primeiro corte, no estado de São Paulo. Piracicaba, ESALQ, 1963. 47p.

MALLOWS, C.L. Some coments on C. Technometrics, Alexandria, 16:661-5, 1973.

MANAHAN, S.E. Environmental chemistry. 4. ed. Boston, Lewis Publ., 1990. 612p.

MARINHO, M.L. \& ALBUQUERQUE, G.A.C. Efeitos do cobre e do zinco na produção de cana-de-açúcar em solos de tabuleiro em Alagoas. Brasil Acucareiro, Rio de Janeiro, 98(6):41-50, 1981. 
MARINHO, M.L. \& IGUE, K. Influência do fósforo e sesquióxidos livres na absorçãop de $\mathrm{Zn}^{65}$ por milho em solos tropicais. In: CONGRESSO BRASILEIRO DE CIÊNCIA DO SOLO, 13., Rio de Janeiro, 1973. Anais. São Paulo, Sociedade Brasileira de Ciência do Solo, 1973. p.158.

MARQUES, M.O. Efeitos da aplicação de lodo de esgoto na produtividade e qualidade da cana-de-açúcar. Piracicaba, SP. 1990. 168p. (Doutorado - Escola Superior de Agricultura “Luiz de Queiroz”/USP).

MARQUES, M.O. ; BELLINGIERI, W.J.; MELO, P.A.; OLIVEIRA, F.C.; FREITAS, J.C.; SANTIAGO,G. Avaliação agroindustrial de cana-de-açúcar cultivada em solo acrescido de lodo de esgoto. In: REUNIÃO BRASILEIRA DE FERTILIDADE DO SOLO E NUTRIÇÃO DE PLANTAS, 21., Petrolina, 1994. Resumo. Petrolina, Sociedade Brasileira de Ciência do Solo, 1994. p.335-6.

MATTIAZZO-PREZOTTO, M.E. Comportamento de cobre, cadmio, cromo, niquel e zinco adicionados a solos de clima tropical em diferentes valores de $\mathrm{pH}$. Piracicaba, 1994. 197p. (Livre-docência - Escola Superior de Agricultura "Luiz de Queiroz"(USP).

MATTIOLLI, C.H. Métodos de seleção de equações de regressão linear múltipla. Piracicaba, 1983. 104p. (Mestrado - Escola Superior de Agricultura "Luiz de Queiroz"/USP). 
Mc GRATH, S.P. \& SMITH, S. Chromium and nickel. In: ALLOWAY, B.J., coord. Heavy metals in soils. New York, John Wiley, 1990. p.40-62.

MELLO, F. A.F.; BRASIL SOBRINHO, M.C.O.; ARZOLLA, S.; SILVEIRA, R.I.; COBRA NETO, A.; KIEHL, J. C. Fertilidade do solo. Piracicaba, Nobel, 1988. 400p.

MELO, W.J. de \& MARQUES, M.O. Há perspectiva de uso nobre do esgoto - o lodo pode ser aproveitado como adubo. Jaboticabal em Notícias, Jaboticabal, 11:6, 1992.

MELO, W.J. Variação do $\mathrm{N}$-amoniacal e $\mathrm{N}$-nítrico em um Latossolo roxo cultivado com milho (Zea mays L.) e com lab-lab (Dolichos lablab).Piracicaba, 1974. 104p. (Doutorado - Escola Superior de Agricultura "Luiz de Queiroz"/USP).

MELO, W.J. de; MARQUES, M.O.; SANTIAGO, G.; CHELLI, R.A.; LEITE, S.A.S. Efeito de doses crescentes de lodo de esgoto sobre as frações da matéria orgânica e CTC de um solo latossolo cultivado com cana-de-açúcar. Revista Brasileira de Ciência do Solo, Campinas, 18:449-55, 1994.

MENCH, M. \& MARTIN, E. Mobilization of cadmium and other metals from two soil by root exudats of Zea mays L. Nicotiana tabacum L. and Nicotiana rustica L. Plant and Soil, The Hague. 132:187-96, 1991. 
MERRIL, M.C.W.; LUKEZIC, F.L.; DLOOM, J.R. Effects on vegetation of irrigation of with waste treatment efluents and possible plant pattogen irrigation interactions. In: SYMPOSIUM OF SOIL AND WATER POLLUTION. Washington, D.C. 1969. Proceedings. Washington, 1969 p.1181-91.

MEYER, J.H. An evaluation of DRIS based on leaf analysis for sugarcane. In: SOUTH AFRICAN SUGAR TECHNOLOGY ASSOCIATION, Durban, 1981. Anais. Durban, Hayne \& Gibson, 1981. p.169-76.

MILLER, R.H.; WHITE, R.K.; LOGAN, T.J.; FOSTER, D.L.; STITZLEIN, J.N. Ohio guide for land application of sewage sludge. Research Bulletin, Columbus. 115p. 1979.

MISHRA, D. \& KAR, M. Nickel in plant growth and metabolism. Botanical Review, New York. $\underline{40}(4): 395-452,1974$.

MITCHELL, R.L. Cobalt and nickel in soils and plant. Soil Science, Baltimore. 60:63$70,1945$.

MORREL, J.L. Phosphate fertilizer value of waste sludges. Phosphorus in Agriculture, Paris, 73:13-9, 1978. 
MORTVEDT, J.J. \& GIORDANO, P.M. Response of corn to zinc and chromium in municipal wastes applied to soil. Journal of Environmental Quality, Madison, 4:171-4, 1975.

MULCHI, C.L.; BELL, P.F.; ADAMU, C.; CHANEY, R.L. Long term availability of metals in sludge amended acid soils. Journal of Plant Nutrition, New York, 10:1149-61, 1987.

NIEUWENHUIZE, J.; POLEY-VOS, C.H.; AKKER, van den A.; DELFT, van. Comparison of microwave and convention extraction techniques for the determination of metals in soil, sediment and sludge samples by atomic spectrometry. Analyst, Netherlands, 116:347-51, 1991.

NIKITIN, A.A. Production and use of trace salts i $n$ fertilizers. In: SAUCHELLI, V., ed. The chemistry and technology of fertilizers. New York, Reinhold, 1960. 692p.

OLIVEIRA, S. S.; JORDÃO, C.P.; BRUNE, W. Retenção de ions $\mathrm{Pb}^{2+}, \mathrm{Cd}^{2+}, \mathrm{Co}^{2+} \mathrm{e}$ $\mathrm{Zn}^{2+}$ em alumina. Ambiente, São Paulo, $\underline{6}(1): 41-4,1992$.

ORLANDO FILHO, J. Absorção dos macronutrientes pela cana-de-açúcar (Saccharum spp) variedade CB41-76, em tres grandes grupos de solos no 
Estado de São Paulo. Piracicaba, 1978. 154p. (Doutorado - Escola Superior de Agricultura "Luiz de Queiroz"/USP).

ORLANDO FILHO, J. \& CAMPOS, H. de. Número ideal de folhas para diagnose foliar em cana de açúcar (cana-planta). Brasil Açucareiro, Rio de Janeiro, 85(1):10-7, 1975.

ORLANDO FILHO, J. \& ZAMBELLO JR. E. A adubação nitrogenada em cana-planta no estado de São Paulo. In: CONGRESSO NACIONAL DA SOCIEDADE DE TÉCNICOS AÇUCAREIROS DO BRASIL, 2., Rio de Janeiro, $1980 . \quad \underline{\text { Anais. }}$ Piracicaba, STAB, 1980. p.190-202.

ORLANDO FILHO, J. Nutrição e adubação da cana de açúcar no Brasil. Rio de Janeiro, IAA/PLANALSUCAR 1983. 368p. (Coleção Planalsucar, 2).

ORLANDO FILHO, J. ZAMBELLO JR., E.; HAAG, H.P. Absorção e remoção do zinco pela cana de açúcar, variedade CB41-76, em tres solos no Estado de São Paulo. Brasil Acucareiro, Rio de Janeiro, 96:21-31, 1980a.

ORLANDO FILHO, J. ZAMBELLO JR., E.; HAAG, H.P. Acumulação de manganes pela parte aérea da cana-de-açúcar em função da idade. Boletim Técnico PLANALSUCAR, Brasília 2(2):3-30, 1980b. 
ORLANDO FILHO, J. ZAMBELLO JR., E.; HAAG, H.P. Efeito do solo e da idade da planta na absorção de boro pela cana de açúcar variedade CB41-76. Brasil

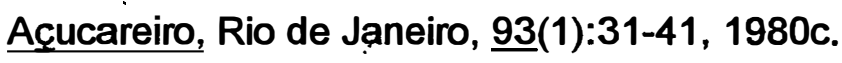

OVERCASH, M.R. \& PAL, D. Design of land treatment systems for industrial wastes, theory and practice. Ann. Arbor, Science Publ., 1979. 684p.

PAGE, A.L. Fate and effects of trace elements in sewage sludge when applied to agricultural lands, a literature review study. U.S. Environ., Prot. Agency, Rep., Washington, D.C., 1983. 108p. (EPA-670, 2-274-005).

PAGE, A.L. \& BINGHAM, F.T. Cadmium residues in the environment. Reviews, New York, 48:1-44, 1973.

PAINTER, A.L.; TOTH, S.J.; BEAR, F.E. Nickel status of New Jersey soils. Soil Science, Baltimore, $\underline{76}: 421-9,1953$.

PARAZZI, C.; GLÓRIA, N.A. da; MATTIAZZO, M.E.; PEREIRA, V.; LOPES, J.J.C. Efeito da vinhaça nas propriedades químicas do solo e composição da cana-deaçúcar. In: CONGRESSO NACIONAL DA SOCIEDADE DOS TÉCNICOS AÇUCAREIROS E ALCOOLEIROS DO BRASIL, 3., São Paulo, 1984. Anais. Piracicaba, STAB, 1984 . p.39-48. 
PEPIN, R.G. \& COLEMAN, P. Paper mill sludge and ash as soil conditioner. Biocycle, Journal of Waste Recycling, Emmaus, 25(4):52-5, 1984.

PIKE, E.B. \& CARRIGTON, E.G. Recent developments in the study of bacteria in the activated sludge process. Water Pollution Control, Don Mills, 71(6):583-605, 1972.

PIPES, W.O. Bulking of activated sludge. Advances Applied Microbiology, New York, 9:185-234, 1967.

POMBO, L.; SALGADO, V.; VOLKWEISS, S.; KLAMT, E. Adsorção de níquel por dois solos: Terra Bruna e estruturada similar e Podzólico Vermelho-Amarelo. Pesquisa Agropecuária Brasileira, Brasília, 24(5):593-8, 1989.

PRATT, P.F. Chromium. In: CHAPMAN, H.D.,ed. Diagnostic criteria for plants and soils, New York, California - Division Agriculture Sciences. 1966. 793p.

PRIMAVESI, O.; KORNDÓRFER, G. H.; DEUBER, R. Extração de minerais por colmos de cana-planta em três solos. In: REUNIÃO BRASILEIRA DE FERTILIDADE DO SOLO E NUTRIÇÃO DE PLANTAS, 20., Piracicaba, 26 a 31 de Julho, 1992. Anais. SBCS / ESALQ e CENA/USP, Fundação Cargill, Piracicaba, 1992. 0.160-1. 
PURVES, D. Trace-element contamination of the environment. New York, Elsevier, 1985. 243p. (Fundamental Aspects of Pollution Control and Environmental Science, 7).

RAIJ, B. van. Fertilidade do solo e e adubação. Piracicaba, Associação Brasileira para Pesquisa da Potassa e do Fosfato, 1991. 343p.

RAIJ, B. van; SILVA, N.M. da; BATAGLIA, O.C.; QUAGGIO, J.A.; HIROCE, R.; CANTARELLA, H.; BELLINAZZI, JR. R.; DECHEN, A.R.; TRANI, P.E.. Calibração do potássio trocável em solos para feijão, algodão e cana-de-açúcar.

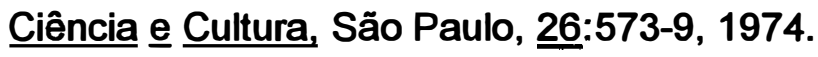

RAIJ, B. van; SILVA, N.M. da; BATAGLIA, O.C.; QUAGGIO, J.A.; HIROCE, R.; CANTARELlA, H.; BellinaZZI, JR. R.; DECHEN, A.R.; tRANI, P.E. . Recomendações de adubação para o Estado de São Paulo. Campinas, Instituto Agronômico, 1985. (IAC -Boletim Técnico). 107p.

RODELLA, A.A. Método de análise de solo, tecido vegetal, vinhaça e torta de filtro. In: ORLANDO FILHO, J. coord. Nutrição e adubação da cana-de-acúcar no Brasil, Piracicaba, IAA/PLANALSUCAR, 1983. p. 351-68. (Coleção Planalsucar, 2). 
ROS, C.O. da; AITA, C.; CERETTAM C.A.; FRIES, M.R. Lodo de esgoto: efeito imediato no milheto e residual na associação aveia-envilhaca. Revista Brasileira de Ciência do Solo, Campinas, 17(2):257-61, 1991.

ROVERS, H.; CAMARGO, O.C.; VALADARES, J.M.A.S. Niquel total e solúvel em DTPA em solos no Estado de São Paulo. Revista Brasileira de Ciência do Solo, Campinas, 7:212-20, 1983.

SABESP. Sanegran: saneamento da Grande São Paulo. (S. Paulo). Superintendência de Divulgação. 1979. 16p

SABEY, B.R. The use of sewage as a fertilizer. In: BEWICK, M.W. Handbook of organic waste conversion, van Nostrand Reinhold, 1980, p.72-107.

SABEY, B.R. The use of sewage sludge as a fertilizer. Environmental Enginering Series, London, $\underline{72}: 108-12,1974$.

SABEY, B.R.; AGBIN, N.N.; MARKSTROM, D.C. Land application of sewage. Journal Environmental Quality, Madison, $\underline{6}: 52-8,1977$.

SACCHI, E. \& BERNARDES, L.F. Efeito da aplicação do lodo de esgoto em propriedades físicas do solo. In: CONGRESSO BRASILEIRO DE CIÊNCIA DO SOLO, 19, Curitiba, 1983, Resumos, Curitiba, SBCS, 1983. p.116. 
SAMUELS, G. Foliar diagnosis of sugarcane. Chicago, Adams Press, 1969. v.3, $326 p$.

SANCHEZ-MARTINS, M.J. \& SANCHEZ-CAMAZANOL, M. Adsorption and mobility of cadmium in natural, uncultivated soils. Journal of Environmental Quality, Madison, 22(4):737-42, 1993.

SANTOS, H.F. Aplicação do lodo de estações de tratamento de esgotos em solos agrícolas. Revista D.A.E., São Paulo, v.39, n.122, p.31-40, 1979.

SANTOS, H.F. Aplicação do lodo de estações de tratamento de esgotos em solos agrícolas. Revista D.A.E., São Paulo, $\underline{39}(122): 31-48,1970$.

SARRUGE, J.R. \& HAAG, H.P. Análises químicas em plantas. Piracicaba, ESALQ/USP, 1974. 56p.

SCHNEIDER, F., ed. Sugar analysis methods. Peterborough, ICUMSA, 1979. $256 p$.

SERRA, C.E. Aplicação de vinhaça complementada com nitrogênio e fósforo em cultura de cana-de-açúcar (Saccharum spp). Piracicaba, 1973. 95p (Doutorado Escola Superior de Agricultura "Luiz de Queiroz"/USP). 
SILVA, F.C. da \& BASSO, L.C. Avaliação da atividade in vivo da fosfatase ácida da folha na diagnose da nutrição fosfórica em cana-de-açúcar. Revista Brasileira de Ciência do Solo, Campinas, 17:371-5, 1993.

SILVA, F.C. da; CAMARGO, A.P. de; ALVES, M.C.; CESAR, M.A.A.; BOVI, R.; MORAES, R.S. de; RIBEIRO, J.C.L. Avaliação das dimensões de parcelas para experimentos com cana-de-açúcar. In: CONGRESSO NACIONAL DA STAB. 5:, Águas de São Pedro, 1993. Anais. Piracicaba, STAB, 1994. p.158-64.

SLAVEK, J. \& PICKERING, W.F. Metal ion interaction with the hydrous oxides of aluminum. Water, Air and Soil Pollution, Dordrecht, 39:201-16, 1988.

SOANE, R.D. \& SAUNDER, D.H. Ni and chromium toxicity of serpentine soils in Southern Rhodesia. Soil Science, Baltimore, 86:322-30, 1959.

SOMMERS, L.E. Chemical composition of sewage sludge and analysis of their potential use as fertilizer. Journal Environmental Quality, Madison, 6:225-31, 1977.

SPOSITO, G. \& BINGHAM, F.T. Computer modelinf of trace metal speciation in soil solutions: correlation with trace metal uptake by higher plants. Journal of Plant Nutrition, New York, $\underline{3}(1 / 4): 39-49,1981$. 
STEVENSON, F.J. \& ARDAKANI, N.S. Organic matter reactions involving micronutrients in soils. Micronutrients in agriculture. In: MORTVEDT, J.J.; GIORDANO, P.M.; LINDSAY, W.L. Micronutrients in Agriculture. Madison, Soil Science Society America, 1972. p.79-114.

STURION, A.C. \& FERNANDES, A.C. Análise direta de cana-de-açúcar pelo método para prensa hidráulica. Boletim Técnico COPERSUCAR. Piracicaba, $\underline{8}: 12-5$, 1979.

SWAINE, D.J. The trace element content of soils. Commonwealth Bureau Soil Science Communication, Brisbane, 48.1955.

TANIMOTO, T. The press method of cane analysis. Hawaii Pers'. Rec. 51(2):133-50, 1964.

TAYLOR, J.M.; IBEABUCHI, I.O.; SISTANI, K.L.; SHUFORD, J.M. Accumulation of some metals by legumes and their extractability from acid mine spores. Journal of Environmental Quality, Madison, 21:176-80, 1992.

TILLS, A.R. \& ALLOWAY, B.J. Use of liquid chromato graph in the study of cadmium speciation in soils solutions from poluted soils. Journal of Soil Science, Oxford, 34:769-81, 1983. 
TISDALE, S. \& NELSON, W. Soil fertility and fertilizers. 3 ed., New York, Mac Millan Publ., 1975.670p.

UNDERWOOD, E.J. Trace elements in soil-plant animal systems. New York, Academic Press, 1977. 417p.

UREN, N.C. From reactions, and availability of nickel in soils. Advances in Agronomy, New York, 48:141-203, 1992.

VALADARES, J.M.A. \& CATANI, J.R. Zinco em solos do Estado de São Paulo. Bragantia, Campinas, $\underline{34}: 133-9,1975$.

VALADARES, J.M.A.L; GAL, M.; MINGELGRIM, U.; PAGE, A.L. Some heavy metals in soils treated with sewage sludge, their effect on yield, and their uptake by plants. Journal of Environmental Quality, Madison, 12(1):49-57, 1983.

VERSTRAETE, W. \& VAERENBERGH, E. van. Aerobic activated sludge. In: REHM, H.J. \& REED, G. (ed.). Biotechnology: a comprehensive treatise. Schonborn, W., V.H.C. Verlagsgesellschaft, , 1986, v. 8.: p.43-113.

VETTORI, L. Métodos de análise do solo. Rio de Janeiro, Ministério da Agricultura, 1969. 24p. (Boletim Técnico, 7). 
VLAMIS, J. \& WILLIANS, E. Utilization of municipal organic wastes as agricultural fertilizers. California Agriculture, Riverside, 25(7):7-9, 1971.

WALKER, J.M. Sewage sludge, management aspects for land application. Biocycle; Journal of Waste Recycling, Emmaus, 16(2):12-23, 1975.

WALKER, J.M. \& WILSON, G.B. Composting sewage sludge. Why? Part I. Biocycle; Journal of Waste Recycling, Emmaus, 14(4):10-2, 1973.

WHITE, J. Toxic action of comman elements towards yeast grouth .I Yeast Technology. London., Champman and Hall, 1954. 286p.

WALSH, L. Land application of slidge on overview. In: HEATINGS ON AGRICULTURAL PRODUCTIVITY AND ENVIRONMENTAL QUALITY. Columbus, 1979. Anais. Columbus, Univ. of Ohio; Agriculture Committee, 1979. p.1-13.

WILLIAMS, C.H. \& STEINBERG, A. Soil sulphur fractions as chemical indices of available sulphur in some australian soils. Australian Journal of Agricultural Research, East Melbourne, 10:340-52, 1959. 
WILLSON, G.B.; PARR, J.F.; EPSTEIN, E.; MARSH, P.B.; CHANEY, R.L.; COLACICCO, D.; BURGE, W.D.; SIKORA, L.J.; TESTER, C.F.; HORNICK, S.; RYAN, J.A. Manual for composting sewage sludge by the Beltsville Aerated-Pile Method. Ohio, Municipal Environmental Research; Cincinati, U.S. Environmental Protection Agency, 1980. 65p.

ZULLO, M.A.T.; COSTA, A.A.; CESAR, M.A.A. Curso de análises tecnológicas de cana-de-açúcar (avaliação da maturação e controle de qualidade da cana-deaçúcar). Campinas, Instituto Agronômico de Campinas, 1988. 53p. 
APÊNDICE 


\section{APÊNDICE 1}

Totais mensais de precipitação pluviométrica e da evaporação do tanque classe "A"(em mm) e médias de temperaturas $\left(\mathrm{em}^{\circ} \mathrm{C}\right)$, no período de abril de 1993 a outubro de 1994.

\begin{tabular}{l|ccccccc}
\hline \multicolumn{1}{c}{ Mês/Ano } & \multicolumn{3}{c}{ Temperatura Média } & $\left.{ }^{\circ} \mathrm{c}\right)$ & \multicolumn{5}{c}{ Balanço Hídrico } & Dias de Precipitaçāo \\
\hline Abril/93 & 29,7 & 16,8 & 23,3 & 57,7 & 130,1 & -72 & 6 \\
Maio & 26,2 & 13,1 & 19,7 & 119,7 & 107,7 & - & 7 \\
Junho & 247 & 11,6 & 18,2 & 47,0 & 82,3 & -35 & 6 \\
Julho & 26,5 & 11,8 & 19,1 & 13,7 & 101,8 & -88 & 2 \\
Agosto & 26,2 & 10,6 & 18,4 & 51,8 & 109,1 & -57 & 6 \\
Setembro & 26,9 & 15,3 & 21,1 & 154,4 & 104,7 & - & 15 \\
Outubro & 30,2 & 17,1 & 23,7 & 73,4 & 173,4 & -100 & 12 \\
Novembro & 32,2 & 18,3 & 25,3 & 199,0 & 225,4 & -56 & 11 \\
Dezembro & 30,2 & 19,5 & 24,8 & 146,4 & 182,4 & -36 & 19 \\
\hline & & & & & & & \\
\hline Janeiro/94 & 30,3 & 19,3 & 24,8 & 174,6 & 173,5 & - & 14 \\
Fevereiro & 33,0 & 20,2 & 26,6 & 154,4 & 168,0 & - & 13 \\
Março & 30,0 & 18,5 & 24,1 & 222,7 & 162,6 & - & 12 \\
Abril & 29,0 & 16,6 & 22,8 & 114,9 & 119,8 & -5 & 9 \\
Maio & 26,8 & 15,0 & 20,9 & 56,2 & 88,4 & -32 & 8 \\
Junho & 27,0 & 10,7 & 18,8 & 24,7 & 121,0 & -96 & 4 \\
Julho & 24,8 & 10,3 & 17,6 & 36,7 & 73,5 & -37 & 6 \\
Agosto & 28,4 & 11,0 & 19,7 & 0,0 & 139,3 & -139 & 0 \\
Setembro & 31,7 & 14,1 & 22,9 & 0,5 & 194,1 & -193 & 1 \\
Outubro & 32,2 & 18,4 & 25,3 & 126,8 & 205,5 & -78 & 12 \\
\hline
\end{tabular}




\section{APÊNDICE 2}

\section{Especificações Técnicas do Espectrometro de Plasma de Emissão Atômica com acoplamento JY-50P, Simultânea.}

- Radiofrequência : 40,68 Mhz e potencia de $1000 \mathrm{~W}$.

- Entrada de gases : plasma (12//min), sheath gás $(0,3 \mathrm{l} / \mathrm{min})$ e o nebulizador (Vgroove) com pressão de 2,5 bares. Vazão da amostra: 1,5 ml/min.

- Sistema óptico : grade holográfica com 3.600 ranhuras (mm), montagem tipo Paschen-Runge e Círculo de Rowland.

- Altura de leitura na tocha : $15 \mathrm{~mm}$

Canais de leitura (mm) : Ca (317,933); Cd (226,502); $\mathrm{Cr}(267,716) ; \mathrm{Cu}(324,754) ; \mathrm{Fe}$ (259,940); K (766,400); Mg (279,079); Mn (259,610); Ni (231,604); P (178,225); Pb $(220,353) ; S(180,672)$ e Zn $(213,856)$. 


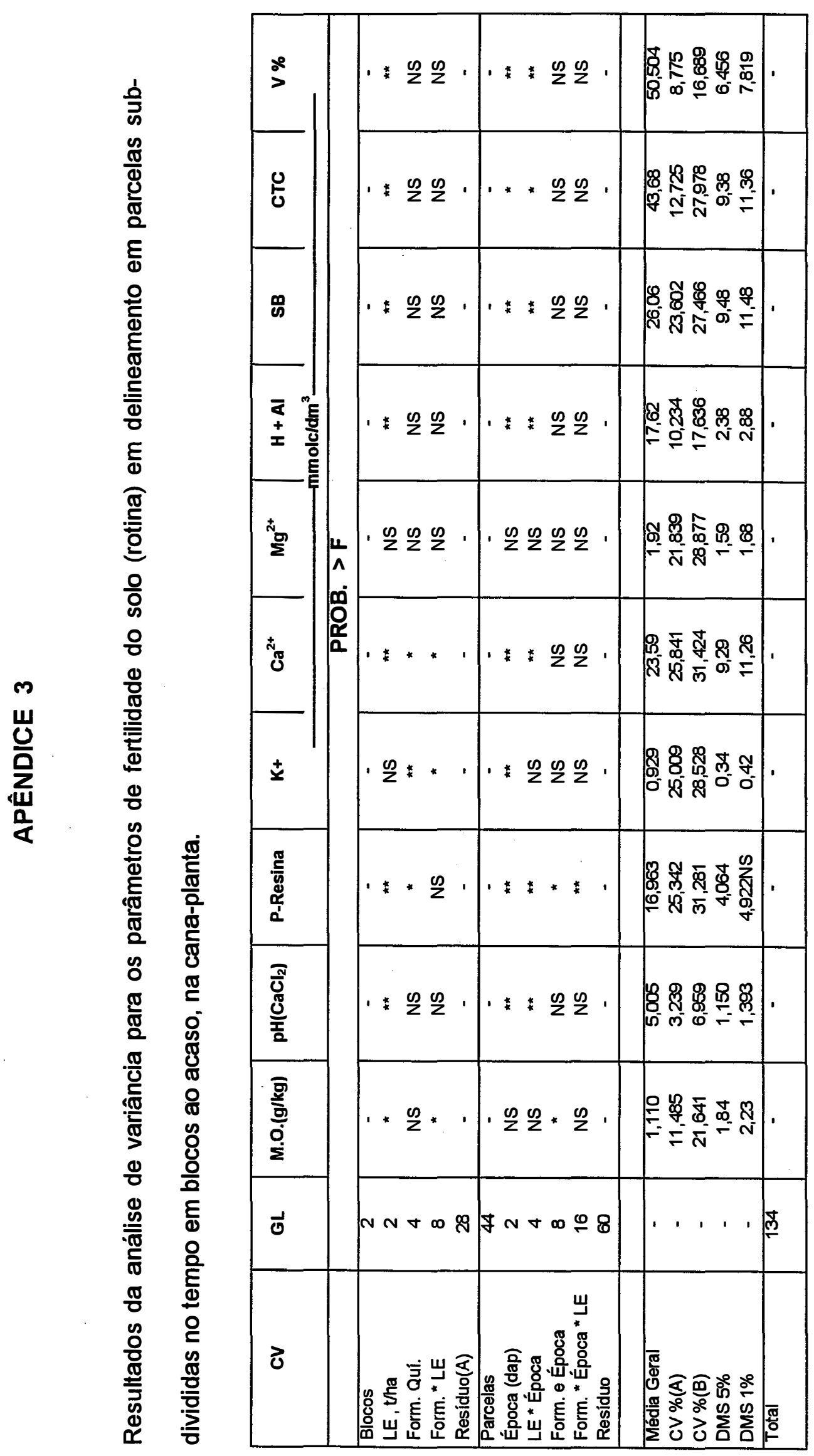




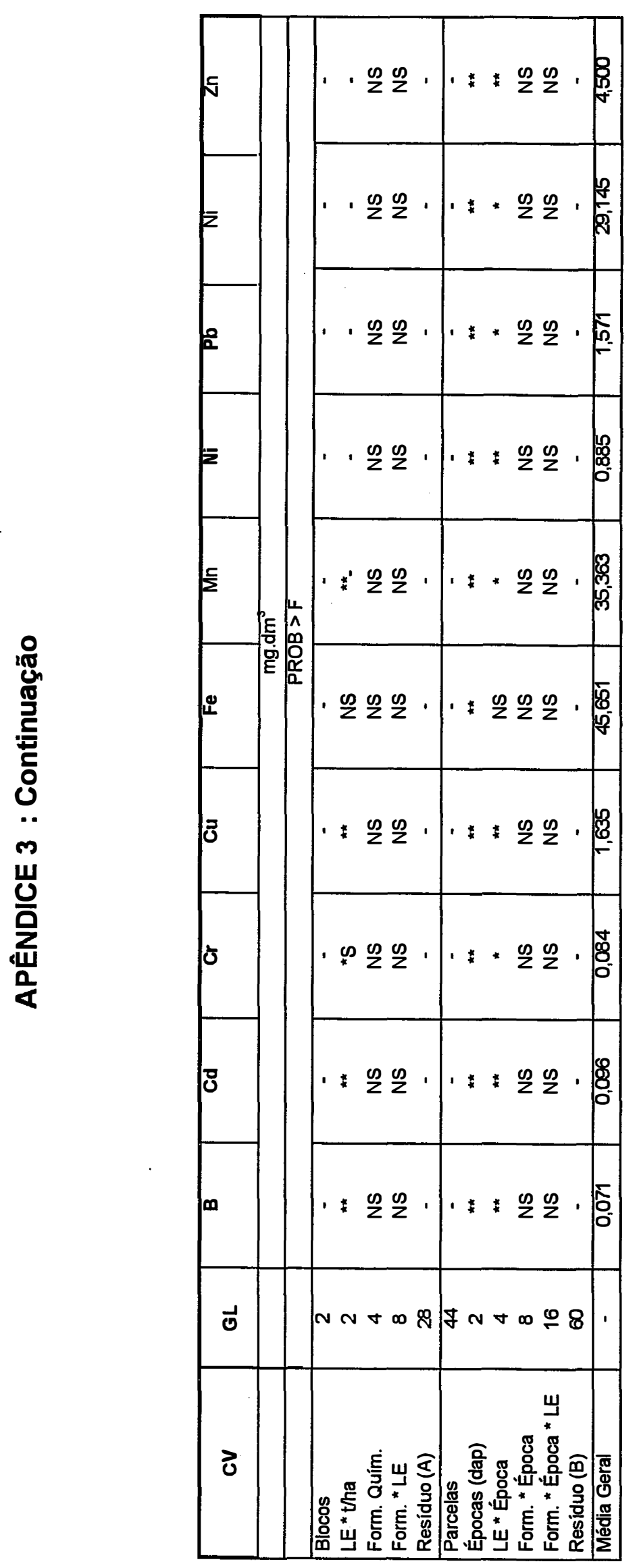




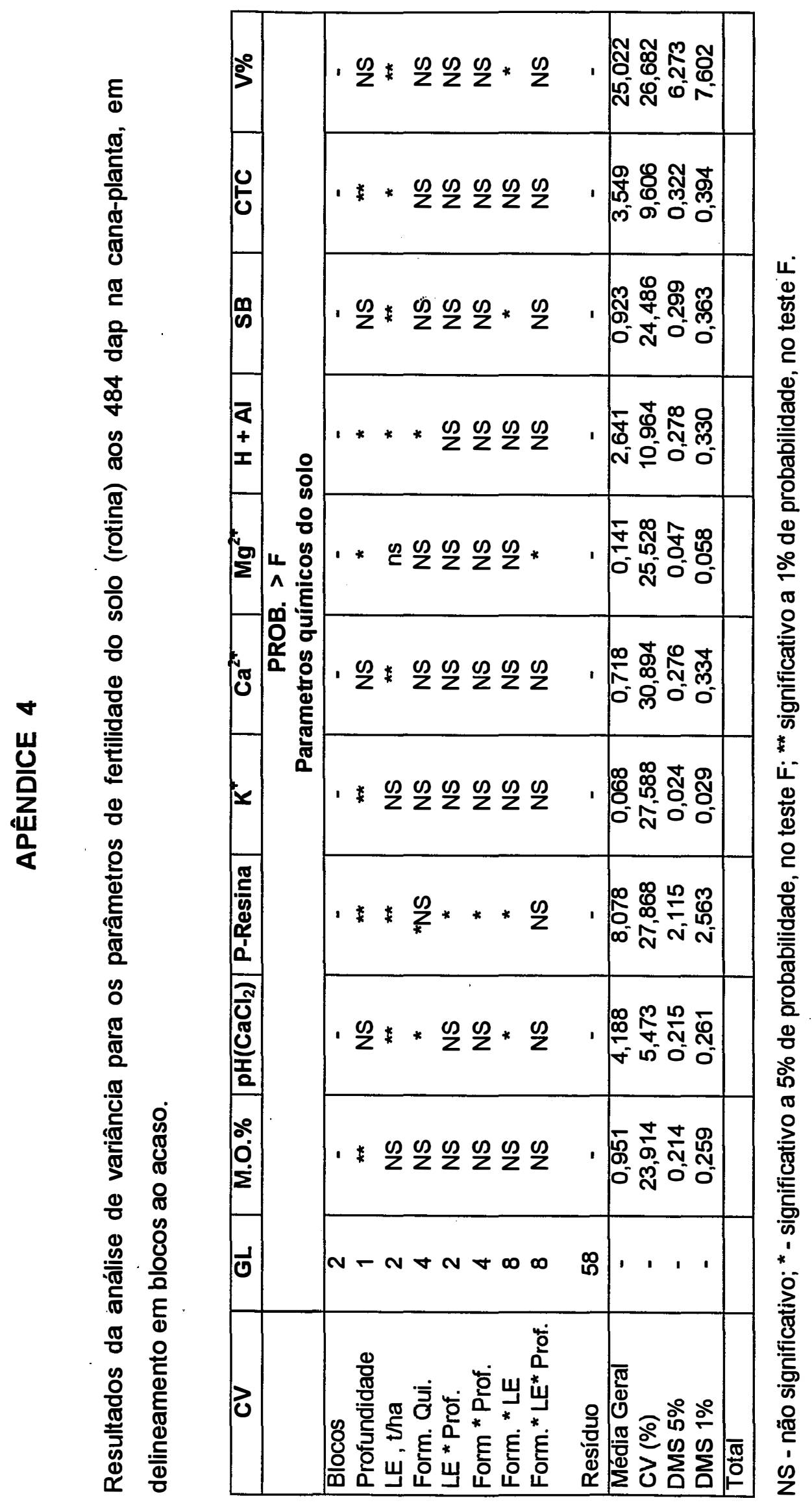




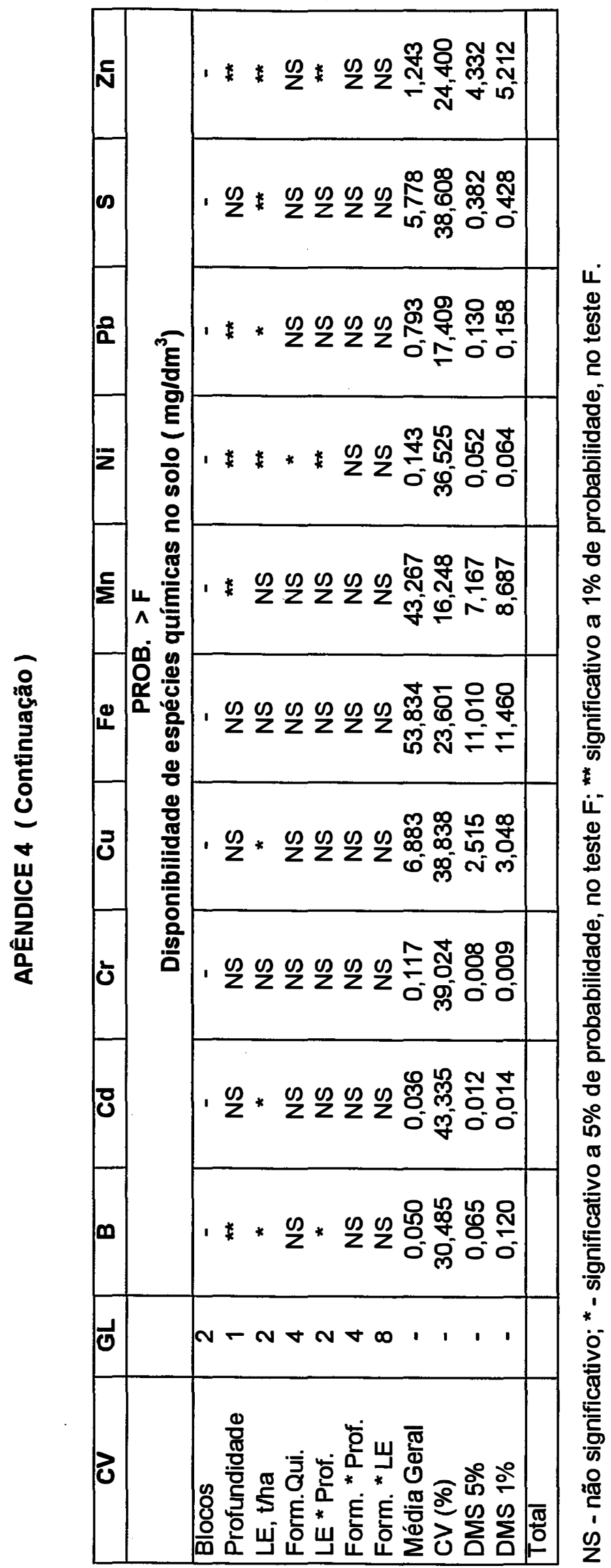




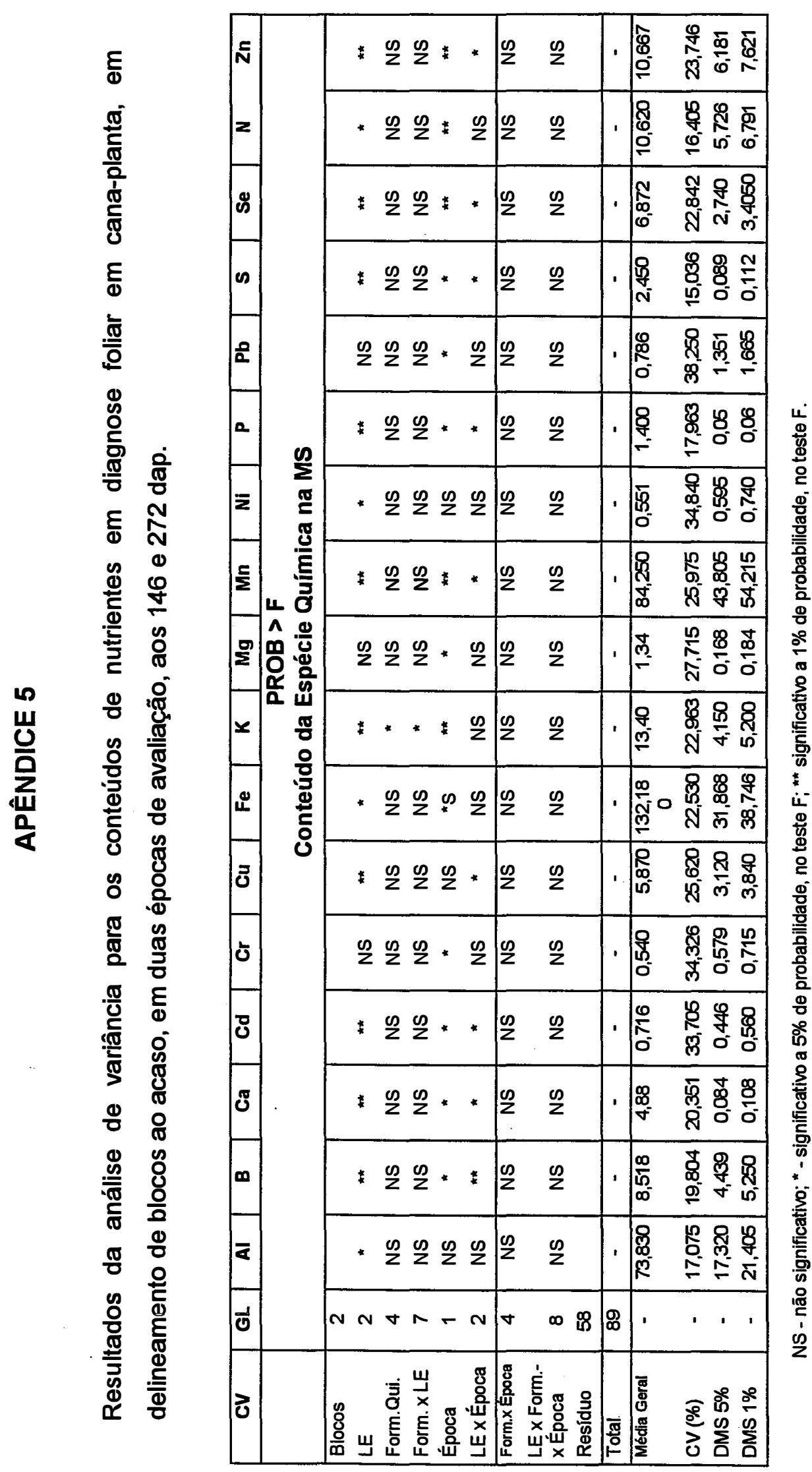




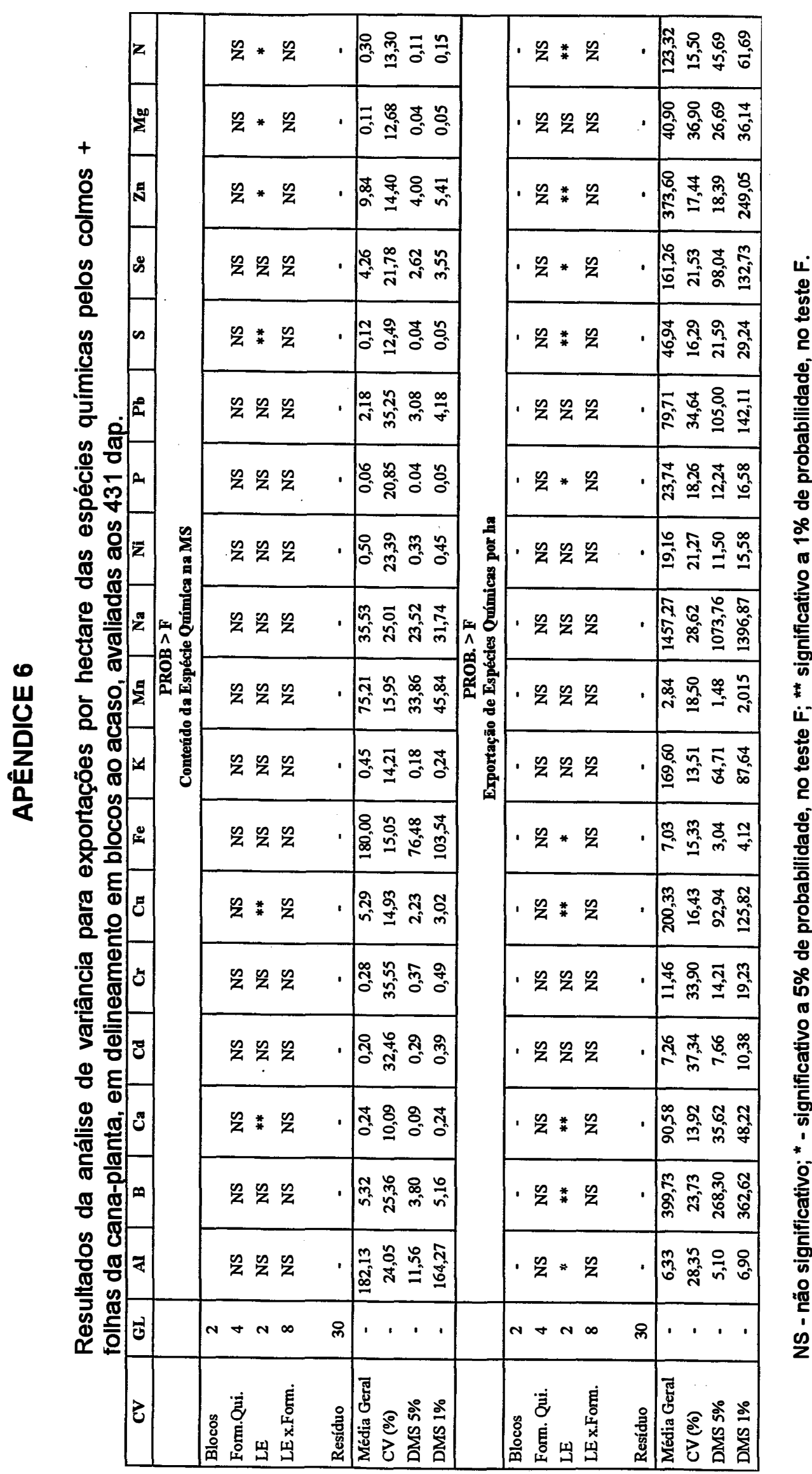




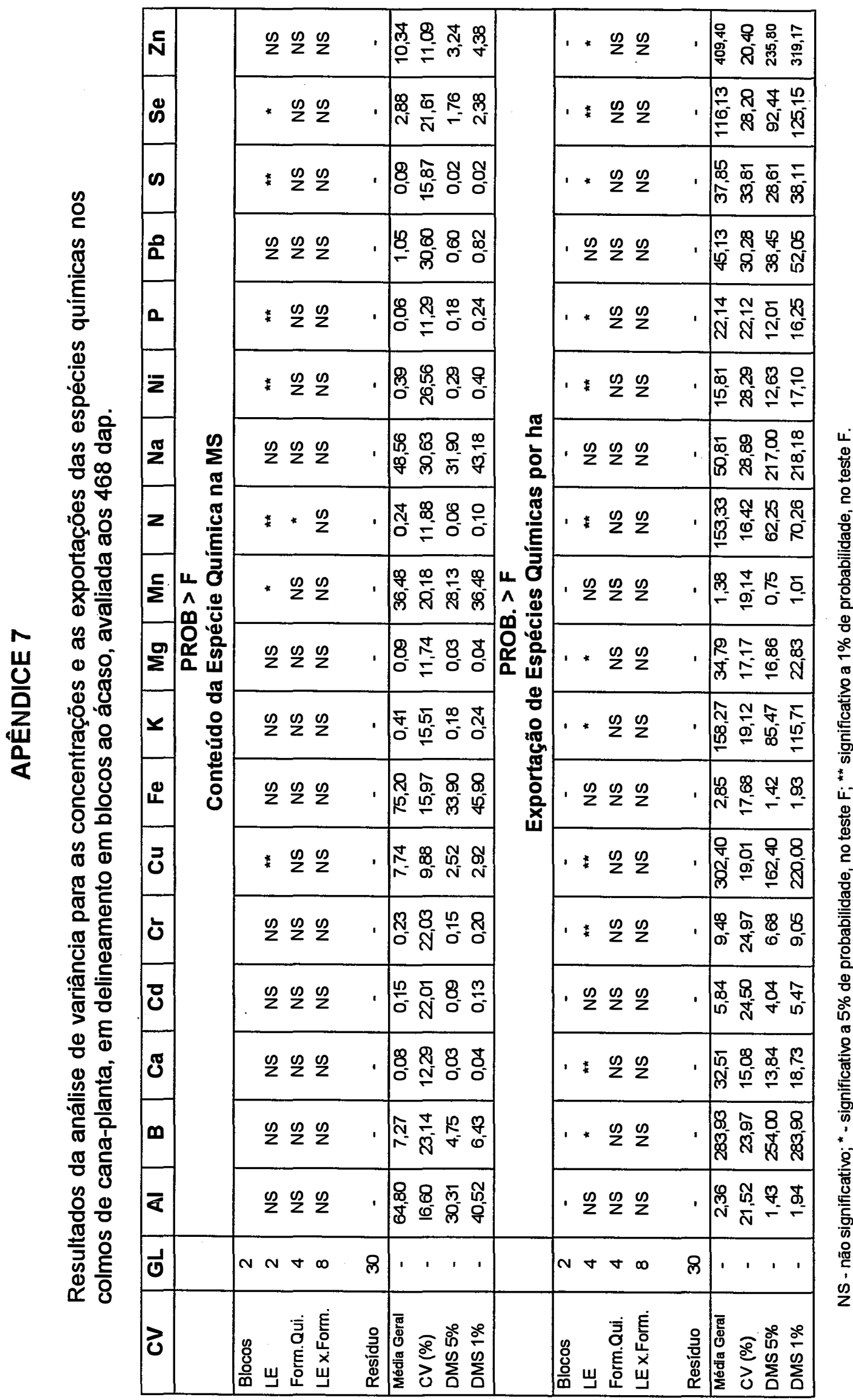




\section{APÊNDICE 8}

Seleção de variáveis preditoras do modelo de produtividade de biomassa por hectare de colmos de cana $(\mathrm{TCH}=\mathrm{Y})$, em teste de todas as possiveis regressões, a partir dos parâmetros de solo (x).

\begin{tabular}{|c|c|c|c|c|c|c|c|c|c|}
\hline $\begin{array}{l}\text { ÍNDICE DE } \\
\text { VARIÁVEIS }\end{array}$ & & $\begin{array}{c}\text { Q.M. } \\
\text { REORESSÃo }\end{array}$ & $\begin{array}{c}\text { Q.M. } \\
\text { RESIDUO }\end{array}$ & VALOR F & PROB.>F & $\begin{array}{l}\text { COEF. } \\
\text { DETERM. }\end{array}$ & $\begin{array}{c}\text { CP DE } \\
\text { MALLOWS }\end{array}$ & $\bar{P}$ & Cp-p \\
\hline 1345 & & 1029,9 & 487,8 & 2,1 & 0,05 & 0,48 & 2,78 & 5 & $-2,22$ \\
\hline 145 & & 1124,9 & 511,2 & 2,2 & 0,10 & 0,37 & 1,97 & 4 & $-2,03$ \\
\hline 123456810 & & 807,8 & 422,6 & 1,9 & 0,22 & 0,72 & 7,04 & 9 & $-1,96$ \\
\hline 134510 & & 909,7 & 494,4 & 1,8 & 0,20 & 0,50 & 4,10 & 6 & $-1,90$ \\
\hline 13456910 & & 822,4 & $4 \mathfrak{3 , 0}$ & 1,8 & 0,23 & 0,63 & 6,17 & 8 & $-1,83$ \\
\hline 123456910 & & 796,4 & 437,8 & 1,8 & 0,24 & 0,71 & 7,19 & 9 & $-1,81$ \\
\hline 1458 & 、 & 960,5 & 515,6 & 1,9 & 0,19 & 0,42 & 3,22 & 5 & $-1,77$ \\
\hline 1345910 & & 848,1 & 488,7 & 1,7 & 0,22 & 0,56 & 5,23 & 7 & $-1,76$ \\
\hline 13458 & & 867,5 & 517,8 & 1,7 & 0,23 & 0,48 & 4,43 & 6 & $-1,57$ \\
\hline 14 & & 1216,4 & 547,1 & 2,2 & 0,12 & 0,27 & 1,47 & 3 & $-1,53$ \\
\hline 134 & & 1018,5 & 540,2 & 1,9 & 0,15 & 0,34 & 2,48 & 4 & $-1,53$ \\
\hline 13459 & & 858,9 & 522,6 & 1,6 & 0,24 & 0,48 & 4,50 & 6 & $-1,50$ \\
\hline
\end{tabular}

S.Q. TOTAL 899,7

G.L. TOTAL 16

\section{Modelo Genérico:}

onde: $y=a+b . X_{1}+c . X_{2}+d . X_{3}+\ldots+n . X_{16}$, onde:

$X_{1}=p H\left(C_{2 a C l}\right) ; X_{2}=H+A l ; X_{3}=C a ; X_{4}=M g ; X_{5}=K ; X_{6}=P($ resina $) ; X_{7}=S ; X_{8}=C u ; X_{9}=Z n ;$

$X_{10}=B ; X_{11}=F e ; X_{12}=N i ; X_{13}=M n ; X_{14}=P b ; X_{15}=$ Cd e $X_{16}=$ CTC. 


\section{APÊNDICE 9}

Seleção de variáveis preditoras do modelo de produtividade de sacorose aparente por hectare nos colmos de cana (Tpol/ha), em teste de todas as possiveis regressões, a partir dos parâmetros de solo $(x)$.

\begin{tabular}{|c|c|c|c|c|c|c|c|c|}
\hline $\begin{array}{l}\text { ÍNDICE DE } \\
\text { VARLÁVEIS }\end{array}$ & $\begin{array}{c}\text { Q.M. } \\
\text { REQRESSĀO }\end{array}$ & $\begin{array}{c}\text { Q.M. } \\
\text { RESíduo }\end{array}$ & VALORF & PROB $>F$ & $\begin{array}{c}\text { COEF. } \\
\text { DETERM. }\end{array}$ & $\begin{array}{c}\text { CPDE } \\
\text { MALLOWS }\end{array}$ & $\mathbf{P}$ & Gp-p \\
\hline 123467891012 & 14,2 & 0,06 & 249,1 & 0,01 & 1,00 & 9,33 & 11 & $-1,67$ \\
\hline 12346789101112 & 12,9 & 0,07 & 191,9 & 0,01 & 0,99 & 11,06 & 12 & $-0,94$ \\
\hline 1234567891012 & 12,9 & 0,07 & 185,5 & 0,01 & 0,99 & 11,13 & 12 & $-0,86$ \\
\hline 123456789101112 & 11,8 & 0,10 & 120,9 & 0,01 & 1,00 & 13,00 & 13 & $0, \infty 0$ \\
\hline 1234567891011 & 12,3 & 2,04 & 6,1 & 0,08 & 0,96 & 71,74 & 12 & 59,74 \\
\hline 12456789101112 & 12,3 & 2,11 & 5,8 & 0,08 & 0,95 & 73,74 & 12 & 61,74 \\
\hline 124567891011 & 13,5 & 1,64 & 8,2 & 0,03 & 0,95 & 74,38 & 11 & 63,38 \\
\hline 12345678910 & 13,5 & 1,84 & 7,3 & 0,04 & 0,95 & 82,45 & 11 & 71,44 \\
\hline 12345678912 & 13,4 & 1,92 & 7,0 & 0,04 & 0,94 & 85,49 & 11 & 74,49 \\
\hline 1234567891112 & 12,2 & 2,54 & 4,8 & 0,10 & 0,94 & 87,02 & 12 & 75,01 \\
\hline 123456789 & 14,9 & 1,59 & 9,4 & 0,01 & 0,94 & 86,30 & 10 & 76,30 \\
\hline 12345678911 & 13,4 & 1,97 & 6,8 & 0,04 & 0,94 & 87,5 & 11 & 76,58 \\
\hline
\end{tabular}

S.Q. TOTAL 142,0

G.L. TOTAL 16

\section{Modelo Genérico:}

onde: $y=a+b \cdot X_{1}+c \cdot X_{2}+d \cdot X_{3}+\ldots+n \cdot X_{16}$, onde:

$X_{1}=p H\left(C_{C a C l}\right) ; \quad X_{2}=H+A l ; \quad X_{3}=C a ; \quad X_{4}=M g ; \quad X_{5}=K ; \quad X_{6}=P($ resina $) ; X_{7}=S ; X_{8}=$ $\mathrm{Cu} ; X_{9}=Z n ; X_{10}=P b ; X_{11}=F e ; X_{12}=B ; X_{13}=N i ; X_{14}=M n ; X_{15}=C d$ e $X_{16}=$ CTC. 


\section{APÊNDICE 10}

Seleção de variáveis preditoras do modelo de produtividade de açúcar teórico recuperável por hectare nos colmos de cana (TAH-y), em teste de todas as possíveis regressões, a partir dos parâmetros de solo (x).

\begin{tabular}{|c|c|c|c|c|c|c|c|c|}
\hline $\begin{array}{l}\text { ÍNDICE DE } \\
\text { VARIÁVEIS }\end{array}$ & $\begin{array}{c}\text { Q.M. } \\
\text { REGRESSĀO }\end{array}$ & $\begin{array}{c}\text { Q.M. } \\
\text { REsíduo }\end{array}$ & VALORF & PROB $>F$ & $\begin{array}{l}\text { COEF. } \\
\text { DETERM. }\end{array}$ & $\begin{array}{c}\text { CPDE } \\
\text { MALLOWS }\end{array}$ & $\bar{P}$ & Cp-p \\
\hline 1246789 & 10,2 & 1,2 & $\overline{8,61}$ & 0,01 & 0,90 & 5,48 & 8 & $-2,52$ \\
\hline 14456789 & 8,9 & 1,3 & 6,83 & 0,02 & 0,90 & 7,26 & 9 & $-1,74$ \\
\hline 124678910 & 8,9 & 1,3 & 6,74 & 0,02 & 0,90 & 7,31 & 9 & $-1,69$ \\
\hline 12346789 & 8,9 & . 1,3 & 6,71 & 0,02 & 0,90 & 7,33 & 9 & $-1,67$. \\
\hline 124689 & 11,1 & 1,6 & 6,83 & 0,01 & 0,84 & 6,03 & 7 & $-0,99$ \\
\hline 1245678910 & 8,0 & 1,5 & 5,26 & 0,04 & 0,90 & 9,11 & 10 & $-0,89$ \\
\hline 123456789 & 8,0 & 1,5 & 5,25 & 0,04 & 0,90 & 9,12 & 10 & $-0,88$ \\
\hline 1234678910 & 8,0 & 1,5 & 5,14 & 0,04 & 0,90 & 9,20 & 10 & $-0,80$ \\
\hline 1245689 & 9,5 & 1,8 & 5,19 & 0,02 & 0,84 & 7,95 & 8 & $-0,05$ \\
\hline 1234689 & 9,5 & 1,8 & 5,19 & 0,02 & 0,84 & 7,96 & 8 & $-0,04$ \\
\hline 14911 & 16,6 & 1,3 & 12,70 & 0,01 & 0,83 & 0,98 & 5 & $-0,01$ \\
\hline
\end{tabular}

S.Q. TOTAL 79,3

G.L. TOTAL 16

\section{Módelo Genérico:}

onde: $y=a+b \cdot X_{1}+c \cdot X_{2}+d . X_{3}+d . . .+n \cdot X_{16}$, onde:

$X_{1}=\mathrm{pH}\left(\mathrm{CaCl}_{2}\right) ; \quad \mathrm{X}_{2}=\mathrm{H}+\mathrm{Al} ; \quad \mathrm{X}_{3}=\mathrm{Ca} ; \quad \mathrm{X}_{4}=\mathrm{Mg} ; \quad \mathrm{X}_{5}=\mathrm{K} ; \quad \mathrm{X}_{6}=\mathrm{P}($ resina $) ; \mathrm{X}_{7}=\mathrm{S} ; \mathrm{X}_{8}=$ $\mathrm{Cu} ; X_{9}=Z n ; X_{10}=P b ; X_{11}=B ; X_{12}=N i ; X_{13}=M n ; X_{14}=C d ; X_{15}=$ Fe e $X_{16}=$ CTC. 


\section{APÊNDICE 11}

Seleção de variáveis preditoras do modelo de produção de biomassa por hectare de colmos de cana $(y)$, em teste de todas as possiveis regressões, a partir dos conteúdos foliares e elementos $(x)$.

\begin{tabular}{|c|c|c|c|c|c|c|c|c|}
\hline $\begin{array}{l}\text { ÍNDICE DE } \\
\text { VARIÁVEIS }\end{array}$ & $\begin{array}{c}\text { Q.M. } \\
\text { REORESSÃO }\end{array}$ & $\begin{array}{c}\text { Q.M. } \\
\text { RESiduo }\end{array}$ & VALORF & PROB $>F$ & $\begin{array}{c}\text { COEF. } \\
\text { DETERM. }\end{array}$ & $\begin{array}{c}\text { CPDE } \\
\text { MALLOWS }\end{array}$ & $\mathbf{P}$ & Cp-p \\
\hline 4510 & 1671,9 & 362,0 & 4,6 & 0,02 & 0,58 & $-2,38$ & 4 & $-6,38$ \\
\hline 3510 & 1671,8 & 362,0 & 4,6 & 0,02 & 0,56 & $-2,17$ & 4 & $-6,18$ \\
\hline 45811 & 1448,1 & 320,5 & 4,5 & 0,02 & 0,64 & $-1,11$ & 5 & $-6,12$ \\
\hline 5610 & 1632,8 & 372,7 & 4,4 & 0,03 & 0,54 & $-2,03$ & 4 & $-6,04$ \\
\hline 10 & 3240,5 & 442,9 & 5,3 & 0,02 & 0,36 & $-4,03$ & 2 & $-6,03$ \\
\hline 610 & 2019,0 & 413,3 & 4,9 & 0,03 & 0,45 & $-3,00$ & 3 & $-6,00$ \\
\hline 14510 & 1397,5 & 340,8 & 4,1 & 0,03 & 0,62 & $-0,87$ & 5 & $-5,87$ \\
\hline 45710 & 1393,3 & 342,5 & 4,1 & 0,03 & 0,62 & $-0,85$ & 5 & $-5,86$ \\
\hline 410 & 1958,5 & 423,4 & 4,6 & 0,03 & 0,43 & $-2,85$ & 3 & $-5,85$ \\
\hline 510 & 1945,8 & 425,5 & 4,6 & 0,03 & 0,44 & $-2,81$ & 3 & $-5,82$ \\
\hline 458 & 1555,2 & 393,8 & 3,9 & 0,04 & 0,52 & $-1,76$ & 4 & $-5,76$ \\
\hline
\end{tabular}

\section{Modelo Genérico:}

onde: $y=a+b . X_{1}+c . X_{2}+d . X_{3}+\ldots+n . X_{16}$, onde:

$X_{1}=N ; X_{2}=P ; X_{3}=K ; X_{4}=C a ; X_{5}=M g ; X_{6}=S ; X_{7}=C u ; X_{8}=Z n ; X_{9}=P b ; \quad X_{10}=B ; X_{11}=$ Se; $X_{12}=N i ; X_{13}=C d ; X_{14}=F e ; X_{15}=M n$ e $X_{16}=A l$. 


\section{APÊNDICE 12}

Seleção de variáveis preditoras do modelo de produção de sacarose aparente por hectare (Tpol/ha) nos colmos de cana (y), em teste de todas as possíveis regressões, a partir dos conteúdos foliares dos elementos $(x)$.

\begin{tabular}{|c|c|c|c|c|c|c|c|c|}
\hline $\begin{array}{l}\text { INDDICE DE } \\
\text { VARLIÁVEIS }\end{array}$ & $\begin{array}{c}\text { Q.M. } \\
\text { REQRESSĀO }\end{array}$ & $\begin{array}{c}\text { Q.M. } \\
\text { REsíduo }\end{array}$ & VALOR F & PROB,PF & $\begin{array}{c}\text { COEF. } \\
\text { DETERM. }\end{array}$ & $\begin{array}{c}\text { CPDE } \\
\text { MALLOWS }\end{array}$ & $P$ & Cp-p \\
\hline 14 & 55,5 & 2,6 & 21,5 & 0,01 & 0,78 & $-1,25$ & 3 & $-4,25$ \\
\hline 1411 & 38,3 & 2,5 & 15,6 & 0,01 & 0,81 & $-0,23$ & 4 & $-4,23$ \\
\hline 14911 & 29,6 & 2,4 & 12,5 & 0,01 & 0,83 & 0,93 & 5 & $-4,07$ \\
\hline 1456911 & 21,0 & 2,0 & 10,6 & 0,01 & 0,89 & 2,95 & 7 & $-4,04$ \\
\hline 134 & 37,9 & 2,6 & 14,7 & 0,01 & 0,80 & 0,08 & 4 & $-3,92$ \\
\hline 13411 & 29,3 & 2,5 & 11,8 & 0,01 & 0,83 & 1,19 & 5 & 3,81 \\
\hline 145911 & 24,2 & 2,3 & 10,5 & 0,01 & 0,85 & 2,19 & 6 & $-3,81$ \\
\hline 134911 & 24,2 & 2,3 & 10,5 & 0,01 & 0,85 & 2,22 & 6 & $-3,78$ \\
\hline 149 & 37,7 & 2,6 & 14,3 & 0,01 & 0,80 & 0,29 & 4 & $-3,75$ \\
\hline 146911 & 24,2 & 2,3 & 10,3 & 0,01 & 0,85 & 2,29 & 6 & $-3,71$ \\
\hline 14511 & 29,2 & 2,5 & 11,6 & 0,01 & 0,82 & 1,30 & 5 & $-3,70$ \\
\hline
\end{tabular}

S.Q. TOTAL 141,9

G.L. TOTAL 16

\section{Modelo Genérico:}

onde: $y=a+b . x_{1}+c . x_{2}+d . x_{3}+\ldots+n . x_{16}$, onde:

$X_{1}=N ; \quad X_{2}=P ; \quad X_{3}=K ; \quad X_{4}=C a ; X_{5}=M g ; X_{6}=S ; \quad X_{7}=S e ; X_{8}=F e ; X_{9}=C u ; X_{10}=Z n ; X_{11}$

$=\mathrm{Pb} ; X_{12}=B ; X_{13}=\mathrm{Ni} ; X_{14}=\mathrm{Ca} ; X_{15}=M n$ e $X_{16}=A l$. 


\section{APÊNDICE 13}

Seleção de variáveis preditoras do modelo de produção de açúcar teórico recuperável na indústria por hectare (TAH) nos colmos de cana $(y)$, em teste de todas as possíveis regressões, a partir dos conteúdos foliares dos elementos (x).

\begin{tabular}{|c|c|c|c|c|c|c|c|c|}
\hline $\begin{array}{l}\text { INDICE DE } \\
\text { VARIÁVEIS }\end{array}$ & $\begin{array}{c}\text { Q.M. } \\
\text { REQRESSĀO }\end{array}$ & $\begin{array}{c}\text { Q.M. } \\
\text { REsíduo }\end{array}$ & VALORF & PROB.>F & $\begin{array}{c}\text { COEF. } \\
\text { DETERM. }\end{array}$ & $\begin{array}{c}\text { CPDE } \\
\text { MALLOWS }\end{array}$ & $\mathbf{P}$ & Cp-p \\
\hline 14 & 31,8 & 1,3 & 24,3 & 0,01 & 0,80 & $-1,80$ & 3 & $-4,79$ \\
\hline 1411 & 21,7 & 1,3 & 17,0 & 0,01 & 0,82 & $-0,53$ & 4 & $-4,53$ \\
\hline 14611 & 16,7 & 1,3 & 13,3 & 0,01 & 0,84 & 0,75 & 5 & $-4,25$ \\
\hline 146 & 21,5 & 1,3 & 16,1 & 0,01 & 0,81 & $-0,23$ & 4 & $-4,23$ \\
\hline 134 & 21,5 & 1,3 & 16,0 & 0,01 & 0,81 & $-0,20$ & 4 & $-4,21$ \\
\hline 149 & 21,4 & 1,4 & 15,8 & 0,01 & 0,81 & $-0,13$ & 4 & $-4,13$ \\
\hline 1468911 & 11,8 & 1,1 & 11,1 & 0,01 & 0,89 & 2,89 & 7 & $-4,11$ \\
\hline 1456911 & 11,8 & 1,1 & 11,0 & 0,01 & 0,89 & 2,94 & 7 & $-4,06$ \\
\hline 147 & 21,4 & 1,4 & 15,5 & 0,01 & 0,81 & 2,04 . & 4 & $-4,04$ \\
\hline 124611 & 13,7 & 1,2 & 11,4 & 0,01 & 0,86 & 1,97 & 6 & $-4,02$ \\
\hline 14911 & 16,6 & 1,3 & 12,7 & 0,01 & 0,83 & 0,98 & 5 & $-4,01$ \\
\hline
\end{tabular}

S.Q. TOTAL 79,3

G.L. TOTAL 16

\section{Modelo Genérico:}

onde: $y=a+b . X_{1}+c . X_{2}+d . X_{3}+\ldots+n . X_{16}$, onde:

$X_{1}=N ; X_{2}=P ; X_{3}=K ; X_{4}=C a ; X_{5}=S i ; X_{6}=C u ; X_{7}=F e ; X_{8}=M n ; X_{9}=M g ; X_{10}=Z n ; X_{11}$ $=\mathrm{Pb} ; \mathrm{X}_{12}=\mathrm{Se} ; \mathrm{X}_{13}=\mathrm{B} ; \mathrm{X}_{14}=\mathrm{Ni} ; \mathrm{X}_{15}=\mathrm{Cd} \mathrm{e} \mathrm{X}_{16}=\mathrm{Al}$. 